Gerônimo Freitas do Amaral

\title{
AVALIAÇÃO DO FRESAMENTO DE AÇO ENDURECIDO CONSIDERANDO-SE ASPECTOS ECONÔMICOS, SOCIAIS E AMBIENTAIS
}

\author{
Dissertação submetida ao Programa de \\ Pós-Graduação em Engenharia Mecâ- \\ nica da Universidade Federal de Santa \\ Catarina para a obtenção do Grau de \\ Mestre em Engenharia Mecânica. \\ Orientador: Prof. João Carlos \\ Espíndola Ferreira, Ph.D. \\ Coorientador: Prof. Carlos Alberto \\ Martin, Dr.
}

Florianópolis

2016 
Ficha de identificação da obra elaborada pelo autor, através do Programa de Geração Automática da Biblioteca Universitária da UFSC.

Amaral, Gerônimo Freitas do

AVALIAÇÃO DO FRESAMENTO DE AÇO ENDURECIDO CONSIDERANDO

SE ASPECTOS ECONÔMICOS, SOCIAIS E AMBIENTAIS / Gerônimo

Freitas do Amaral ; orientador, João Carlos Espíndola

Ferreira ; coorientador, Carlos Alberto Martin. -

Florianópolis, SC, 2016.

$99 \mathrm{p}$.

Dissertação (mestrado) - Universidade Federal de Santa Catarina, Centro Tecnológico. Programa de Pós-Graduação em Engenharia Mecânica .

Inclui referências

1. Engenharia Mecânica. 2. Fresamento. 3. Trajetória de ferramenta. 4. Aço ferramenta. 5. Sustentabilidade. I.

Ferreira, João Carlos Espíndola. II. Martin, Carlos Alberto - III. Universidade Federal de Santa Catarina. Programa de Pós-Graduação em Engenharia Mecânica. IV. Título. 
Gerônimo Freitas do Amaral

\section{AVALIAÇÃO DO FRESAMENTO DE AÇO ENDURECIDO CONSIDERANDO-SE ASPECTOS ECONÔMICOS, SOCI- AIS E AMBIENTAIS}

Esta Dissertação foi julgada adequada para obtenção do Título de "Mestre em Engenharia Mecânica", e aprovada em sua forma final pelo Programa de Pós-Graduação em Engenharia Mecânica.

Florianópolis, 2 de agosto de 2016.

Prof. Armando Albertazzi Gonçalves Jr., Dr. Eng.

Coordenador do Curso

Prof. João Carlos Espíndola Ferreira, Ph.D. - Orientador

Universidade Federal de Santa Catarina

Prof. Carlos Alberto Martin, Dr. - Coorientador

Universidade Federal de Santa Catarina

\section{Banca Examinadora:}

Prof. Walter Lindolfo Weingaertner, Dr.-Ing.

Universidade Federal de Santa Catarina

Prof. Milton Pereira, Dr.

Universidade Federal de Santa Catarina

Prof. Carlos Henrique Ahrens, Dr.

Universidade Federal de Santa Catarina 

Dedico à minha família. 



\section{AGRADECIMENTOS}

Ao professor João Carlos Espíndola Ferreira Ph.D., pela orientação e apoio ao decorrer do mestrado.

Aos colegas do Grupo de Integração da Manufatura (GRIMA), com as conversas, debates e descontraídos encontros.

A Universidade Federal de Santa Catarina e o Programa de PósGraduação em Engenharia Mecânica por fornecer e manter uma formação acadêmica de excelente qualidade.

Ao Colégio Técnico Industrial de Santa Maria (CTISM) onde se realizou os testes de usinagem e avaliação do ambiente de usinagem nos aspectos relacionados ao tripé da sustentabilidade. Em especial ao professor Dr. Eng. Moacir Eckhardt pela disposição da utilização da infraestrutura do Laboratório de Usinagem CNC-CTISM quando solicitado, ainda responsável na formação de grande parte da minha vida acadêmica, sempre auxiliando e orientando de maneira esplêndida.

A empresa Favorit Aços Especiais - Matriz Cachoeirinha/RS, no fornecimento do material utilizado no fomento da pesquisa, em especial a Bruna Cardoso qual foi o contato no fornecimento do material.

Ao Cnpq no apoio financeiro ao conceder a bolsa de estudo.

A minha mãe Ceres, no apoio incondicional nas decisões tomadas e sempre ao meu lado nos bons e maus momentos.

A Alana, sempre ao meu lado em incentivo e ajuda.

Ao meu pai Ériton Coelho do Amaral (in memorian), o qual deixou o mundo terreno no meio do período do meu mestrado, homem que sempre foi o padrão a ser seguido e que tenho o maior orgulho de ser filho.

E a todos que de forma direta ou indiretamente contribuíram para que eu desenvolvesse minha pesquisa e concluísse que não estão citados anteriormente. 

"A melhor maneira de prever o futuro é inventá-lo" Alan Kay 



\section{RESUMO}

No cenário atual da manufatura há diversas preocupações das organizações industriais em manter a competitividade e excelência em seus produtos e serviços. Atualmente, com o grande consumo de produtos manufaturados os engenheiros necessitam desenvolver com frequência cada vez maior novos portfólios de produtos para oferecer aos consumidores. Paralelamente, aspectos relacionados à preservação ambiental têm sido cada vez mais valorizados pelos consumidores, e empresas que incluem em seus processos elementos ligados à sustentabilidade podem ter um diferencial competitivo no mercado. Na confecção de produtos muitas vezes, utilizam-se matrizes para dar forma aos materiais, as quais são fabricadas por processo de usinagem e posteriormente submetidas a tratamentos térmicos para melhorar o desempenho. Nesse contexto, esta pesquisa busca contribuir para a fabricação de matrizes usinadas no estado endurecido, com o intuito de alcançar uma boa superfície usinada. Além disto, faz-se uma análise no que tange o tripé da sustentabilidade abordando as dimensões ambiental, econômica e social. Neste trabalho são fresadas cavidades em peças de aço ferramenta AISI/SAE D6 tratadas termicamente (60 HRC de dureza), utilizando ferramentas de metal duro com revestimento. Foram estabelecidas três diferentes trajetórias de usinagem: ziguezague, paralelo ao perfil e trocoidal, além de diferentes valores de velocidade de corte, verificando o desgaste da ferramenta de corte e integridade da superfície usinada. Ainda, monitorou-se a energia ativa exigida pela máquina, a emissão acústica e luminosidade do ambiente. Os resultados obtidos mostram que a usinagem do material endurecido permite obter uma qualidade adequada da superfície usinada, no que se refere aos parâmetros de rugosidade $R_{a}$ e $R_{t}$, destacando-se que o melhor resultado de rugosidade correspondeu à trajetória trocoidal, que também resultou no menor desgaste no gume, porém com tempo de usinagem três vezes maior que na usinagem com as outras duas trajetórias utilizadas nos ensaios. Quanto à avaliação da sustentabilidade, uma abordagem para isto foi aplicada nos ensaios, permitindo obter valores de parâmetros de usinagem que resultam em melhorias na dimensão ambiental e social, sem perdas no âmbito econômico.

Palavras-chave: Fresamento, Trajetórias de Ferramentas, Aços Endurecidos, Rugosidade, Sustentabilidade. 



\begin{abstract}
In the recent manufacturing perspective there are several concerns of industry organizations to maintain competitiveness and excellence in its products and services. Currently, with the large consumption of manufactured products, engineers need to progressively develop new portfolios of products to offer to consumers. Meanwhile, aspects related to environmental protection have been increasingly appreciated by consumers, making companies that include in their processes elements related to sustainability to have a competitive edge in the market. It's common to use dies and molds in the manufacturing of products, which are manufactured by machining process and subsequently subjected to heat treatments in order to improve performance. In this context, the present research aims to contribute to the manufacture of machined dies and molds in the hardened state, so as to achieve a good machined surface. Furthermore, this analysis includes the triple bottom line of sustainability by addressing the environmental, economic and social dimensions. In this work pockets are milled in AISI/SAE D6 tool steel parts (60 HRC hardness) using coated carbide tools. Three different trajectories of machining were established: zigzag, parallel to the profile and trochoidal, as well as different cutting speed values to check the wear of the cutting tool and integrity of the machined surface. In addition, it was monitored the active power required by the machine, the acoustic emission and ambient light. The results achieved indicate that machining of hardened material allows to obtain a good quality of the machined surface, in relation to $R a$ and $R t$ roughness parameters, pointing up that the best result surface roughness corresponded to the trochoidal path, which also resulted in less tool wear, but with machining time was three times higher than in the other two machining tool paths used for the tests. Regarding the assessment of sustainability, an approach was applied in the tests, allowing values of machining parameters that result in improvements in social and environmental aspects, without losses in the economic field.
\end{abstract}

Keywords: Milling, Tool Paths, Hardened Steel, Roughness, Sustainability. 



\section{LISTA DE FIGURAS}

Figura 1 - Três distintos paradigmas da manufatura. Fonte: [13]......................26

Figura 2 - Fresamento de forma frontal e tangencial. Fonte: [20].....................27

Figura 3 - Fluxo de fabricação com tecnologias assistidas por computador.......30

Figura 4 - Cunha de corte, planos e resultantes do processo. Fonte: [16] ...........31

Figura 5 - Dureza do material da ferramenta em função da temperatura. Fonte:

[31].

Figura 6 - Relação dureza e tenacidade para diferentes materiais de ferramentas.

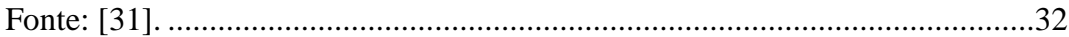

Figura 7 - Parâmetros de profundidade de corte $\left(a_{p}\right)$, profundidade radial $\left(a_{e}\right)$ e

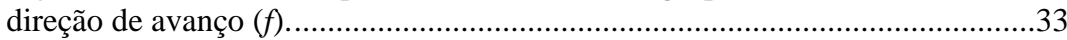

Figura 8 - Fresamento concordante (esq.) e discordante (dir.). Fonte: [34]. .....34 Figura 9 - Consumo de energia e rugosidade $R_{a}$ para diferentes trajetórias de

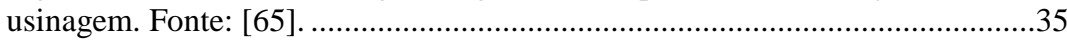

Figura 10 - Caminho da trajetória trocoidal no fresamento frontal. Fonte: [66].

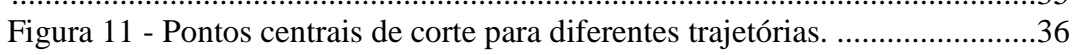

Figura 12 - Zonas de estudo para caracterização de superfícies. Fonte: [45].....38

Figura 13 - Parâmetro de rugosidade $R_{a}$. Fonte: [46] ........................................38

Figura 14 - Parâmetro de assimetria da superfície ("Skewness"). Fonte: [46]...39 Figura 15 - Relação das condições de corte e integridade superficial. Fonte: [47].

Figura 16 - Faixas de rugosidade $R_{a}$ obtidas para diferentes processos de usinagem. Fonte: ASME/ANSI B46.1-1985 apud [47].

Figura 17 - Papel da manufatura industrial em um sistema de sustentabilidade.

Fonte: [53].

Figura 18 - A utilização de energia em máquinas de usinagem na Toyota. Fonte: [58].

Figura 19 - Relação do consumo de energia e redução de emissões com a reciclagem do metal duro na fabricação de novas ferramentas de corte. Fonte: [59].

Figura 20 - Avaliação do processo de usinagem segundo diretrizes e métricas.46 Figura 21 - Rugosímetro RP-200 utilizado na medição das superfícies usinadas.

Figura 22 - Monitoramento da emissão acústica, luminosidade do ambiente e consumo de energia pela máquina ferramenta com aquisição dados por meio de softwares e registro do datalog ....................................................................50

Figura 23 - Transdutor de energia MULTI-K 120 KRON.................................51

Figura 24 - Diagrama de ligação para a medição do consumo de energia. .........51

Figura 25 - Inserto para acabamento e desbaste (a), ferramenta Ø16mm utilizada

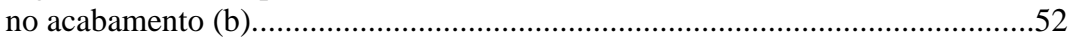

Figura 26 - Modelo computacional e medidas do corpo de prova a ser fabricado. 
Figura 27 - Trajetória zigue zague (esquerda), paralela ao perfil (centro) e

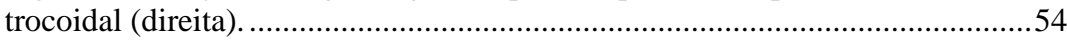

Figura 28 - Regiões de medição da rugosidade no corpo de prova.....................56 Figura 29 - Níveis de observações necessárias para análise no âmbito do tripé da sustentabilidade, adaptado de [72]

Figura 30 - Modelo para a confecção do mapa de impactos relacionados ao processo de fabricação.

Figura 31 - Etapas da metodologia proposta para avaliação do processo de fabricação relacionado ao tripé da sustentabilidade.

Figura 32 - Microscopia do gume lado "80" inserto número 10.

Figura 33 - Evolução do parâmetro de rugosidade $R_{a}$ e $R_{t}$ para a combinação ZZ60.

Figura 34 - Insertos empregados na velocidade de corte de $60 \mathrm{~m} / \mathrm{min}$ e avanço de $0,07 \mathrm{~mm}$ por dente ao final de quatro experimentos, mostrando o lascamento no gume principal

Figura 35 - Evolução dos valores de rugosidade $R_{a}$ e $R_{t}$ para combinação PP60.

Figura 36 - Evolução dos parâmetros de rugosidade $R_{a}$ e $R_{t}$ medidos na combinação PP85.

Figura 37 - Evolução dos parâmetros de rugosidade $R_{a}$ e $R_{t}$ medidos na combinação ZZ85.

Figura 38 - Desgaste ferramenta de corte, insertos 3 e $4\left(\mathrm{VB}_{\max }\right) \ldots \ldots \ldots \ldots \ldots \ldots \ldots \ldots . . . . . . . . . .66$

Figura 39 - Desgaste dos insertos 5 e 6 (a, b) e insertos 7 e 8 (c,d)...................66

Figura 40 - Rugosidades $R_{a}$ e $R_{t}$ para combinação TR85....................................67

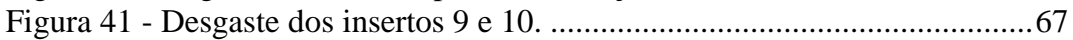

Figura 42 - Relação da velocidade de corte com parâmetro de rugosidade $R_{z}$

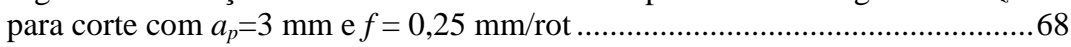

Figura 43 - Perfil de rugosidade da superfície usinada para $f=0,1 \mathrm{~mm} / \mathrm{rot}$ e $a_{p}=0,5 \mathrm{~mm}$ : (a) $\mathrm{v}_{\mathrm{c}}=283 \mathrm{~m} / \mathrm{min}$; (b) $\mathrm{v}_{\mathrm{c}}=141 \mathrm{~m} / \mathrm{min}$; e (c) $\mathrm{v}_{\mathrm{c}}=71 \mathrm{~m} / \mathrm{min}$.

Fonte:[46]

Figura 44 - Evolução dos parâmetros de rugosidade na combinação TR60. .....69 Figura 45 - Desgaste nos insertos 11 e 12 referentes a usinagem da combinação TR60.

Figura 46 - Relação do tempo de corte e a rugosidade Ra para duas ferramentas e condições diferentes [24].

Figura 47 - Faixas de rugosidade $R_{a}$ para o processo de fabricação por

fresamento. Fonte: adaptado de [47]

Figura 48 - Energia ativa consumida durante a usinagem dos corpos de prova. 73 Figura 49 - Emissão de $\mathrm{CO}_{2}$ para o tempo de usinagem de uma hora de utilização de energia.

Figura 50 - Perfil típico da pressão sonora captada durante um ensaio a uma distância de $500 \mathrm{~mm}$ da porta frontal da máquina ferramenta. ...........................8 Figura 51 - Volume total de cavaco removido. Figura 52 - Custos relacionados aos consumos energéticos dos equipamentos, infraestrutura e materiais necessários para o processo de fabricação. 
Figura 53 - Laboratório de usinagem do CTISM - UFSM..................................83

Figura 54 - Ícones presentes no mapa de impacto. .............................................8

Figura 55 - Mapa de impacto referente ao fresamento do aço SAE D6 no

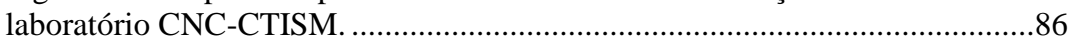





\section{LISTA DE TABELAS}

Tabela 1 - Potenciais métricas do processo de fabricação sustentável com foco na usinagem. Fonte: [57].

Tabela 2 - Especificações do centro de usinagem ROMI D600.........................49

Tabela 3 - Composição química do aço SAE D6. Fonte [64] ..............................53

Tabela 4 - Tratamentos aplicados aos corpos de prova........................................56

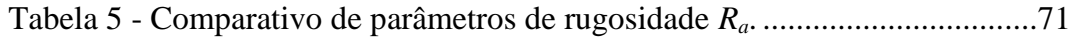

Tabela 6 - Média de valores do parâmetro $R_{s k}$ medidos para cada combinação.71

Tabela 7 - Resultados referentes ao desgaste dos insertos para diferentes

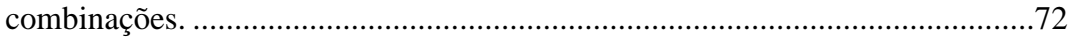

Tabela 8 - Tempos de ciclo para as diferentes trajetórias. ..................................74

Tabela 9 - Classificação das entradas do processo para o aspecto ambiental. ...75

Tabela 10 - Classificação dos das entradas do processo para o aspecto social. .76

Tabela 11 - Classificação dos das entradas do processo para o aspecto

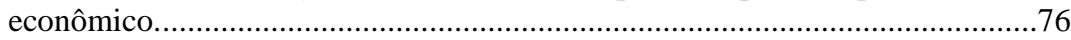

Tabela 12 - Resultados da quarta etapa do método de avaliação da

sustentabilidade abrangendo as dimensões ambiental, social e econômica. 



\section{SUMÁRIO}

1

1.1

INTRODUÇÃO. 21

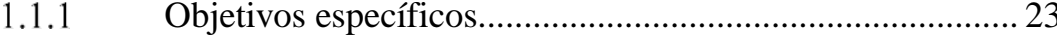

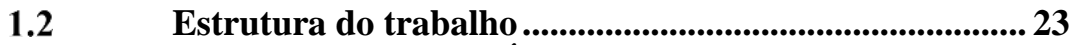

2 REFERENCIAL TEÓRICO...................................... 25

$2.1 \quad$ Processo de usinagem................................................................ 25

2.2 Usinagem com ferramenta de geometria definida.......... 26

2.3 Fresamento................................................................................ 27

$2.4 \quad$ Usinagem CNC ................................................................28

2.5 Ferramentas computacionais de auxílio à usinagem $\mathrm{CNC}$ 29

2.6 Ferramentas de corte ......................................................30

$2.7 \quad$ Parâmetros de corte .......................................................33

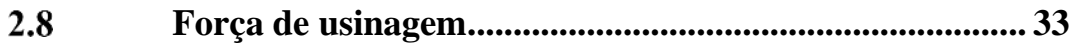

$2.9 \quad$ Trajetórias de corte ...............................................................34

2.10 Aços endurecidos e aços ferramenta.................................... 36

2.11 Avaliação de superfícies usinadas ......................................... 37

2.12 Sustentabilidade ....................................................................... 41

2.13 Sustentabilidade na usinagem .............................................. 42

2.14 Avaliação do processo de usinagem no âmbito da

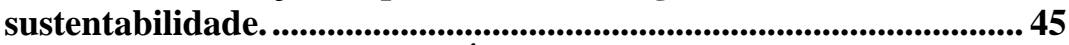

3 MATERIAIS E MÉTODOS.......................................... 49

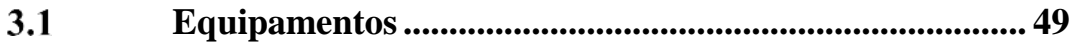

3.1.1 Máquina Ferramenta …................................................. 49

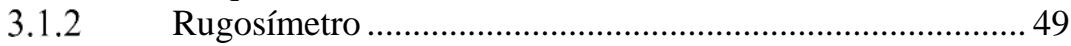

3.1.3 Luxímetro e medidor de emissão acustica........................... 50

3.1.4 Medidor de Energia........................................................... 51

3.1.5 Microscópio para medição dos desgastes do gume .............. 52

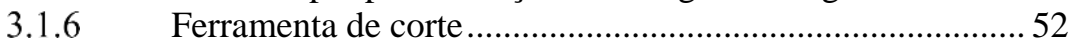

3.2 Material para ensaio ....................................................5 53

3.3 Corpo de prova para ensaio ..................................................... 53

3.4 Trajetórias para acabamento ............................................. 54

3.5 Parâmetros de corte ....................................................54

3.6 Planejamento experimental...............................................55

3.7 Condução experimental ....................................................5 57

3.8 Procedimentos para avaliação de sustentabilidade do processo 57 
4.1 Avaliação da usinagem do aço ferramenta ..................... 61

4.1.1 Acabamento da superfície usinada e desgaste de ferramenta 61

4.1.2 Energia ativa despendida na remoção de material .............. 73

4.2 Avaliação sustentável nas dimensões ambiental, econômica e social .............................................................................74

4.2.1 Identificação dos insumos para usinagem.......................... 74

4.2.2 Classificação das observâncias referentes à dimensão

ambiental 75

4.2.3 Classificação da dimensão social ........................................ 75

4.2.4 Classificação da dimensão econômica ................................. 76

4.2.5 Resultados referentes às dimensões ambiental, econômica e social 77

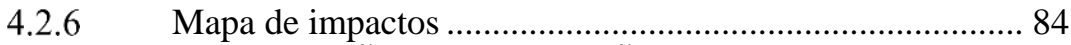

5 CONCLUSÕES E SUGESTÕES PARA TRABALHOS

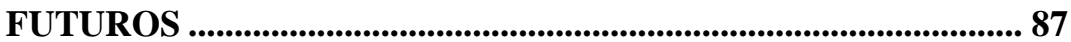

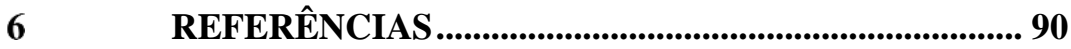




\section{INTRODUÇÃO}

A situação atual do mercado globalizado tem causado grandes mudanças no ambiente de produção, uma vez que no passado o mercado era voltado principalmente para empresas locais. Atualmente, empresas de porte mundial têm atuado em "qualquer lugar do planeta". Em consequência, o consumidor tem acesso a mais escolhas, motivando a compra de um produto com qualidade, confiabilidade, e baixo custo [1].

Com o passar do tempo, as exigências dos clientes em conjunto com a concorrência entre os fabricantes de bens de consumo, levou a indústria de manufatura a expandir opções em relação ao fornecimento de soluções na produção de novos produtos, pelo motivo de que o ciclo de vida até o descarte dos mesmos tem menor duração. Outra necessidade é que as empresas de manufatura forneçam produtos com a qualidade desejada pelos clientes, o que exige a busca por processos enxutos e padronizados evitando os desperdícios na produção [2]. Este cenário do mercado consumidor levou a mudanças nos meios produtivos de maneira a aumentar as capacidades produtivas das empresas de manufatura, bem como desenvolveram-se meios de controle complexos para o melhoramento contínuo da área de fabricação.

A indústria de transformação de bens é muito importante para uma economia (nação) industrializada, correspondendo de $20 \%$ a $30 \%$ de todos os bens e serviços produzidos na totalidade das atividades econômicas [3]. Em geral, quanto maior o nível de atividade de fabricação de um país, maior o padrão de vida de seu povo.

Os processos de usinagem têm uma grande importância na agregação de valor, e em alguns produtos quase que a totalidade da fabricação corresponde a um ou mais processos de usinagem. Acompanhando o progresso dos produtos foram desenvolvidos novos materiais para aplicações de engenharia, novas ferramentas para usinagem e máquinas contendo novas tecnologias. Este desenvolvimento reflete em melhores resultados nos produtos finais se comparados a anteriores.

Juntamente com a crescente demanda por produtos que são fabricados por processos de usinagem, surge a necessidade de inovação tecnológica deste processo, pois as empresas buscam cada vez mais reduzir o custo de fabricação e aumentar a produtividade, visando manter a sua posição em um mercado de alta competitividade global [4]. O processo de usinagem busca atingir resultados quanto ao acabamento das superfícies usinadas, dimensões mais precisas, de acordo com as especificações de fabricação e com o seu uso [5]. 
Nos processos de fabricação adaptam-se os parâmetros do processo e as sequências de operações às necessidades e ao prazo, custo e especificações de acabamento. É comum realizar o cruzamento das informações de parâmetros conhecidos no processamento de produtos semelhantes com modificações de estratégias para que o processo se torne mais rápido, econômico e que continue resultando em produtos com qualidade [6].

No ambiente fabril, os diversos processos de usinagem possibilitam a obtenção diferentes geometrias, além de serem utilizados diversos materiais nos produtos. Dentre os processos de usinagem tem-se o fresamento, mediante o qual obtém-se formas simples e complexas para geometrias tipicamente prismáticas. Grande parte dos moldes para produtos de materiais plásticos, bem como ferramentas para conformação é obtida mediante o fresamento de aços de alta dureza.

$\mathrm{Na}$ fabricação de ferramentas de conformação e injeção plástica são utilizados processos de usinagem convencional para definir a forma desejada e posteriormente usinagens finas para obter do acabamento adequado da ferramenta seguindo os requisitos de projeto [7]. Os processos de usinagem fina (polimento, lapidação e superacabamento) tem baixa taxa de remoção dividida em múltiplos estágios predominantemente manuais. Atualmente há um desenvolvimento da automatização do processo de acabamento com dispositivos especiais aliados a braços robóticos obtendo taxas de rendimento de 10 a $15 \mathrm{~cm}^{2} / \mathrm{min}$, semelhante às operações manuais [8].

É interessante trabalhar acerca dos processos de usinagem de materiais endurecidos, visto que se tem a diminuição de etapas para a obtenção da ferramenta. Ainda possibilita uma superfície adequada pósusinagem para os passos de finalização despendendo menores tempos das tarefas no acabamento manual ou automatizado.

Outra questão levada em conta no âmbito atual é a sustentabilidade na indústria, que leva ao respeito dos meios de fabricação ao meio ambiente, buscando-se minimizar o consumo de energia pelos processos, o descarte correto dos meios lubrirrefrigerantes, e isto proporciona um diferencial ao produto. Acompanhando o desenvolvimento dos meios de produção, busca-se reduzir a quantidade de energia necessária para a transformação da matéria-prima, bem como estudar formas de melhor entendimento dos fenômenos que ocorrem durante a usinagem.

Mudanças nos processos industriais tem reflexo no que diz respeito à sustentabilidade nos âmbitos ambiental, econômico e social. Nas avaliações da sustentabilidade é importante retratar os reais impactos das ocorrências observadas e discuti-las apropriadamente correlacionan- 
do os âmbitos em estudo para correta inferências e identificação de potenciais pontos a realizar melhorias.

\section{$1.1 \quad$ Objetivos}

O presente trabalho tem por objetivo desenvolver uma metodologia de avaliação de sustentabilidade no que diz respeito ao tripé da sustentabilidade, e aplica-la ao processo de usinagem dura por fresamento em regime de acabamento de aços ferramenta.

A metodologia proposta para a avaliação das questões ambientais, econômicas e sociais tem o foco na identificação dos recursos necessários para realizar a usinagem, classificá-los e apresentar os resultados. O estudo da sustentabilidade neste trabalho não estabelece metas de redução ou índices do grau de sustentabilidade da tarefa de fabricação.

\subsubsection{Objetivos específicos}

- Realizar o fresamento de cavidades em aço SAE D6 com a variação da velocidade de corte e trajetórias de corte;

- Qualificar a qualidade obtida por meio dos parâmetros de rugosidade $R_{a}, R_{t}$ e $R_{S K}$

- Medir os desgastes das ferramentas de usinagem;

- Desenvolver metodologia para avaliação da sustentabilidade nos âmbitos ambiental, econômico e social;

- Aplicar a metodologia da avaliação da sustentabilidade no ambiente de fabricação dos corpos de prova de aços ferramenta.

\subsection{Estrutura do trabalho}

Esta dissertação está estruturada em capítulos, onde o primeiro contém a introdução e os objetivos da pesquisa. No capítulo 2 faz-se um referencial teórico quanto aos processos de fabricação direcionados a usinagem com ferramentas de geometria definida, conceitos sobre fresamento, e também apresenta uma breve revisão de temas de usinagem $\mathrm{CNC}$ e sistemas computacionais que possibilitam a usinagem com essa tecnologia. São descritos também os aços endurecidos e os meios de avaliar a superfície usinada, finalizando com conceitos ligados à sustentabilidade em geral e sustentabilidade na usinagem.

No capítulo 3 são descritos os materiais e métodos, apresentando os equipamentos utilizados para a usinagem e obtenção de dados para 
análise. Descreve-se também o método de avaliação do processo de usinagem no que tange o tripé da sustentabilidade.

O capítulo 4 apresenta os resultados obtidos de usinagem do aço ferramenta SAE D6, quanto à rugosidade das superfícies usinadas pelo processo de fresamento em regime de acabamento de cavidades e o desgaste da ferramenta de usinagem, verificando em quais combinações utilizadas, gera um resultado adequado. Apresenta-se também a análise do ambiente em que foram realizados os ensaios quanto aos aspectos ambientais, econômicos e sociais.

No capítulo 5 são apresentadas as considerações finais sobre a pesquisa desenvolvida e sugeridos alguns tópicos a serem abordados em trabalhos futuros. 


\section{REFERENCIAL TEÓRICO}

\subsection{Processo de usinagem}

Os processos de usinagem caracterizam-se pela remoção de material a partir de um objeto sólido (material bruto), sob a forma de cavacos por meio de ferramentas, decorrente das interferências no espaço entre a ferramenta e o material bruto, proporcionado pelo movimento da máquina-ferramenta, até a obtenção de um produto final [9] [10] [11].

Para a realização da usinagem é necessário que ocorra movimento entre peça e a ferramenta, e tais movimentos são classificados como ativos e passivos. Os movimentos ativos são responsáveis diretamente pela remoção de material, enquanto os movimentos passivos são aqueles em que são realizadas as aproximações e retrações da ferramenta em relação à peça, não realizando corte de material [10].

$O$ resultado obtido no processo de remoção de material deve atender as especificações de fabricação quanto ao acabamento da superfície usinada, dimensões e área de aplicação da peça, seguindo planos bem organizados em todos os aspectos ao longo da fabricação e inspeção [5] [12].

Os processos de remoção do material podem ser divididos em três subgrupos: [9]

Corte com ferramenta geometria definida;

Corte com ferramenta geometria não definida;

Processos não convencionais.

A transformação de bens em uma economia industrializada está na ordem de $20 \%$ a $30 \%$ dos bens e serviços produzidos das atividades econômicas, o custo de usinagem corresponde a mais de $15 \%$ do valor de todos os produtos fabricados [3] [13].

Enquanto o processamento de metal por usinagem é comumente associado a grandes indústrias (automobilística, aeroespacial, eletrodomésticos, etc.), a usinagem de metais e ligas desempenha um papel crucial em uma variedade de outras atividades de fabricação, incluindo a usinagem de ultraprecisão de componentes extremamente delicados (Figura 1) [13]. 
Figura 1 - Três distintos paradigmas da manufatura. Fonte: [13].

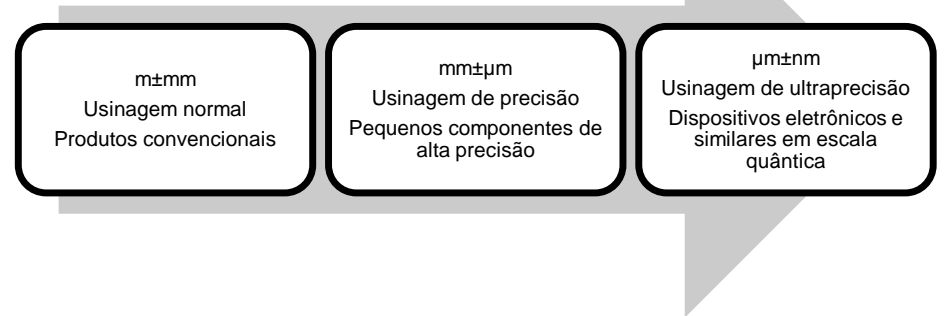

Após o projeto do produto frequentemente surgem problemas quanto à usinagem, causados muitas vezes por tolerâncias apertadas, reduzidos valores de rugosidade, bem como a falta de capacidade das máquinas e insumos disponíveis [14].

Processos de usinagem tradicionais continuam sendo bastante utilizados na indústria apesar dos progressos realizados nos processos de remoção não tradicionais, tais como remoção por descargas elétricas, remoção por laser, plasma e processos eletroquímicos. Não se espera a diminuição da importância da usinagem tradicional em um futuro próximo, uma vez que normalmente leva-se um tempo elevado para que sejam adotados novos processos nas indústrias [15].

Dentre os processos usados para transformar metais, a usinagem é um dos que possuem as condições mais variadas de operação. Uma grande parte das superfícies finais das peças fabricadas nas indústrias é produzida por usinagem. No que se refere ao tamanho de peças, desde componentes de relógios de pulso até apoios das asas de aeronaves com mais de 30 metros de comprimento são obtidos por usinagem. Muitas operações diferentes de usinagem são utilizadas, que podem ter diferentes velocidades de corte, avanços e profundidades, e os cortes podem ser contínuos ou interrompidos, e tais fatores influenciam diretamente a qualidade da peça, a vida da ferramenta, e o tempo de usinagem, que pode corresponder a várias horas ou há poucos segundos [13].

\section{$2.2 \quad$ Usinagem com ferramenta de geometria definida}

O subgrupo 3.2 da norma DIN 8580, que contém o termo "separar", abrange os processos de fabricação com remoção de cavacos por meio de ferramentas com geometria definida, caracterizados pela aplicação de ferramentas com os gumes e planos definidos geometricamente 
[11] [16]. Exemplos de processos de usinagem usando-se ferramentas com geometria definida é o torneamento, aplainamento, brochamento, furação e fresamento, que possuem algumas particularidades quanto ao corte, movimento e formas obtidas.

\subsection{Fresamento}

O processo de usinagem utilizado no desenvolvimento desta pesquisa é o fresamento, e os conceitos relacionados a este processo são apresentados a seguir, com ênfase na usinagem de aços endurecidos.

O fresamento é caracterizado por ser um processo de usinagem destinado à obtenção de variadas formas, geralmente utilizando-se de ferramenta multicortante. A ferramenta efetua o movimento de rotação em torno de seu próprio eixo e a peça e/ou ferramenta desloca-se segundo uma determinada trajetória [17]. O fresamento se diferencia de outros processos de usinagem em que a ferramenta gira (por exemplo, furação, rosqueamento e alargamento) pelo corte interrompido e pelo deslocamento tanto da ferramenta quanto da peça durante a operação de usinagem [18].

O fresamento pode ser dividido em dois grupos principais: periférico ou tangencial, e frontal ou plano (Figura 2) [10] [19]. Outros métodos de fresamento que existem podem ser considerados variações desses dois e dependem do tipo de peça e ferramenta utilizadas [17] [19].

Figura 2 - Fresamento de forma frontal e tangencial. Fonte: [20].

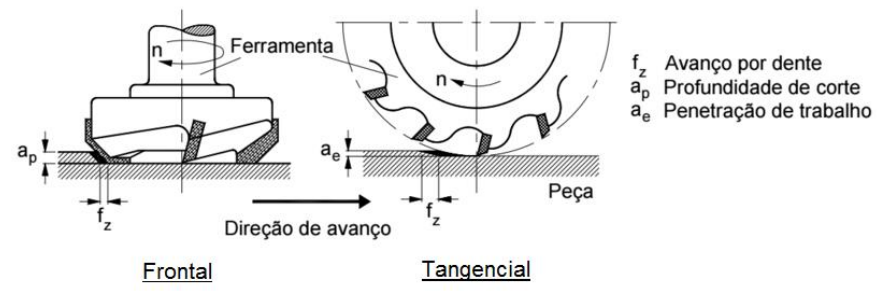

O fresamento frontal (ou de topo) ocorre quando a superfície usinada resulta da ação combinada dos gumes localizados na periferia e na face frontal da fresa, geralmente perpendicular ao eixo da ferramenta [10] [19] [20]. O fresamento de topo é utilizado na execução de superfícies de forma livre, bem como rasgos e cortes de todos os tipos e tamanhos. Estas fresas podem ser de topo simples ou duplo, possuir haste e corpo cilíndricos ou cônicos, e possuir dois, três, quatro, seis ou mais canais [19]. Construtivamente as fresas de topo podem ser inteiriças, 
com insertos ou gumes brasados, ou ainda com insertos intercambiáveis [10] [19].

Os desenvolvimentos em ferramentas de corte não apresentam problemas técnicos na maioria dos casos para fresamento de matrizes e aços ferramenta em uma ampla gama de dureza (31 a 58 HRC). Porém, a fabricação econômica de matrizes e componentes usando apenas usinagem é um desafio e, devido a isto, tem havido um aumento das pesquisas quanto à fabricação de ferramentas somente a partir de usinagem, e um desenvolvimento do conhecimento e da tecnologia no corte de materiais endurecidos para viabilizar economicamente obtenção dessas ferramentas [21].

\subsection{Usinagem CNC}

Em meados da década de 1940 a necessidade de geometrias complexas até então impossíveis ou de difícil execução pelo controle humano na manufatura fez com que John Parsons procurasse alternativas para a fabricação de componentes que seriam usados pela indústria de defesa norte-americana. Parsons utilizou computadores para comandar a movimentação dos eixos de uma fresadora, em pequenos passos incrementais seguindo um caminho previamente definido, criando assim em março de 1952 no Instituto Tecnológico de Massachusetts (MIT) a primeira máquina comanda numericamente [22].

Define-se Controle Numérico (NC - Numerical Control) como uma forma de automação programável de dispositivos capazes de dirigir os movimentos de posicionamento de um órgão mecânico em que os comandos relativos a este movimento são elaborados de forma totalmente automática. Os movimentos são feitos a partir de informações numéricas ou alfanuméricas (números, letras ou outros símbolos), com a capacidade de reprogramação após a tarefa realizada para a produção de outra peça [22] [23]. A aplicação do CNC divide-se em duas áreas [22]:

- Processos de usinagem e outros processos de fabricação;

- Operações de montagem, desenho e inspeção.

$\mathrm{Na}$ usinagem de materiais endurecidos, atualmente alcança-se melhores resultados usando-se máquinas-ferramenta com maior rigidez e boas características de amortecimento, conduzindo maior precisão na usinagem e a um melhor acabamento [24]. Uma máquina CNC é independente da habilidade do operador, facilitando a obtenção de peças com tolerâncias de forma e dimensional dentro de limites desejáveis, juntamente com os requisitos de qualidade da superfície usinada [25]. 
Outro atributo muito importante das máquinas CNC é a capacidade de movimento, precisão e controle. Elas devem possuir uma série de características construtivas, incluindo bases com compósitos, guias hidrostáticas, etc. [24].

Uma característica importante de máquinas $\mathrm{CNC}$ é a capacidade que o conjunto possui de manter elevadas velocidades de avanço na obtenção de geometrias de forma livre. Devido à grande quantidade de informações necessárias para a usinagem em geometrias de forma livre, a máquina normalmente reduz ou até nem atinge o avanço programado, redução esta que pode estar associada às características de rigidez na máquina bem como à capacidade de processamento do CNC [26] .

$\mathrm{O}$ tempo de processamento de um bloco no programa NC corresponde ao tempo necessário para o $\mathrm{CNC}$ interpretar uma linha de programa $\mathrm{NC}$ e converter estas informações em acionamento dos eixos da máquina [26]. Algumas funcionalidades são incorporadas aos CNCs, dentre as quais tem-se a função look ahead, que consiste no préprocessamento das informações das linhas de comando posteriores à que está em execução, permitindo alcançar velocidades de avanço maiores [26].

\subsection{Ferramentas computacionais de auxílio à usinagem $\mathrm{CNC}$}

Empresas de fabricação estão enfrentando sérios desafios e pressões da crescente globalização da economia e do mercado como bem como a rápida evolução da ciência e da tecnologia. Dentre as pequenas e médias empresas, especialmente, tem que reformular o seu método tradicional de fabricação, utilizando tecnologias avançadas, tais como Inteligência Artificial (AI), Gestão do Conhecimento (Knowledge Management - KM), etc. [27]. Na reformulação do processo produtivo um diferencial para as empresas alcançarem o sucesso é a utilização dos sistemas computacionais de auxilio (CAx) em conjunto com os comandos numéricos computadorizados.

Para chegar a um produto final utilizando-se processos de fabricação atuais, normalmente há etapas de fabricação em que se empregam sistemas CAD/CAM. Além das facilidades disponíveis em tais sistemas, outra questão é a grande dificuldade da programação manual de formas complexas.

Em um ambiente de fabricação tradicional $\mathrm{CNC}$, o fluxo de operações normalmente começa na concepção do produto mediante modelos geométricos criados no sistema $\mathrm{CAD}$, e termina com a geração de instruções de usinagem necessárias para converter matéria-prima em 
produtos acabados, com base no modelo geométrico. Na verdade, este processo inclui CAD, CAPP, CAM e CNC, cujas informações fluem em uma única direção [27].

O fluxo de trabalho que é necessária para a produção de uma peça usando uma máquina $\mathrm{NC}$ pode ser resumido como mostra a Figura 3. As tarefas podem ser classificadas como os três tipos seguintes [28]:

- Tarefas off-line: CAD, CAPP, CAM;

- Tarefas online: NC usinagem, monitoramento e medição na máquina;

- Tarefas pós-linha: Inspeção auxiliada por computador (CAI - Computer Aided Inspection), pós-operação.

Figura 3 - Fluxo de fabricação com tecnologias assistidas por computador.

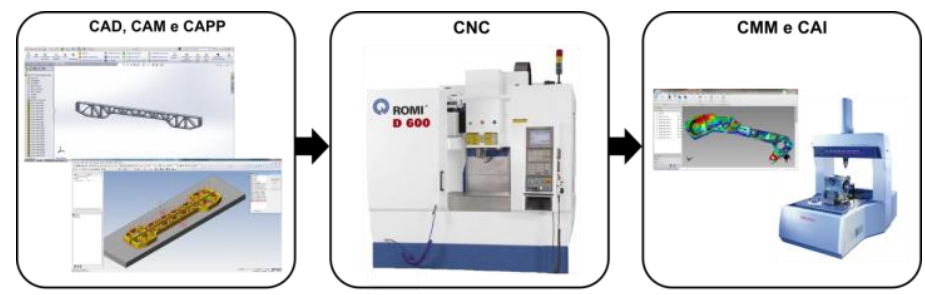

\subsection{Ferramentas de corte}

O elemento de corte (gume) é a parte ativa da ferramenta, e a cunha está localizada na intersecção do flanco e a face da ferramenta. $\mathrm{O}$ ângulo entre estas duas superfícies é designado como o ângulo de cunha $(\beta)$, como mostrado na Figura 4 [16].

As superfícies têm função importante para o corte do material. A inclinação da face influencia na formação do cavaco (forma e tamanho) e, assim, também influencia os esforços durante o corte. A capacidade de suporte de forças que atuam sobre a face está atrelada ao ângulo da cunha e assim também ao ângulo do flanco, com a correta escolha da geometria de acordo com o material a ser usinado [11]. 
Figura 4 - Cunha de corte, planos e resultantes do processo. Fonte: [16].

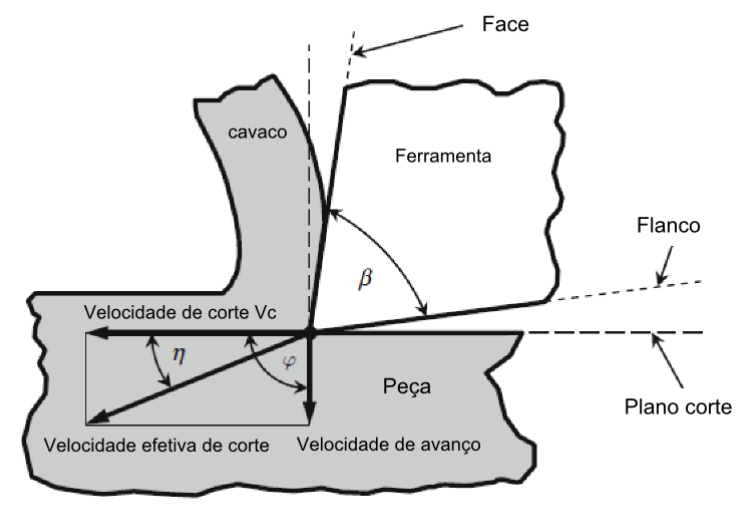

As ferramentas de corte são constituídas por uma haste e uma parte cortante. A parte cortante contempla a face, o flanco, a cunha e o gume da ferramenta [29]. A dinâmica de corte é efetuada pelo ataque da cunha da ferramenta de usinagem sobre a peça com movimento relativo entre as partes. $\mathrm{O}$ rendimento e a durabilidade da ferramenta dependem dos valores dos ângulos da cunha na geometria de corte, além das características dos materiais da ferramenta e peça [11].

Há muitos tipos de materiais para ferramentas, que incluem aço-rápido, metal-duro, cerâmica, CBN e diamante [30]. Dentre as propriedades das ferramentas de corte, tem-se três as seguintes [31]:

- Dureza: a capacidade de manter elevada dureza a temperaturas elevadas é chamada de dureza a quente. Ela é relacionada diretamente à resistência de penetração no material da peça.

- Tenacidade: é definida como a capacidade de um material para absorver energia antes da fratura.

- Resistência ao desgaste: É o desgaste sofrido pela ferramenta de corte até que o mesmo alcance seu tempo de vida para um critério predeterminado de fim de tempo de vida.

A variação da dureza e da tenacidade para diferentes materiais de ferramentas são mostradas nas Figura 5 e Figura 6. 
Figura 5 - Dureza do material da ferramenta em função da temperatura. Fonte: [31].

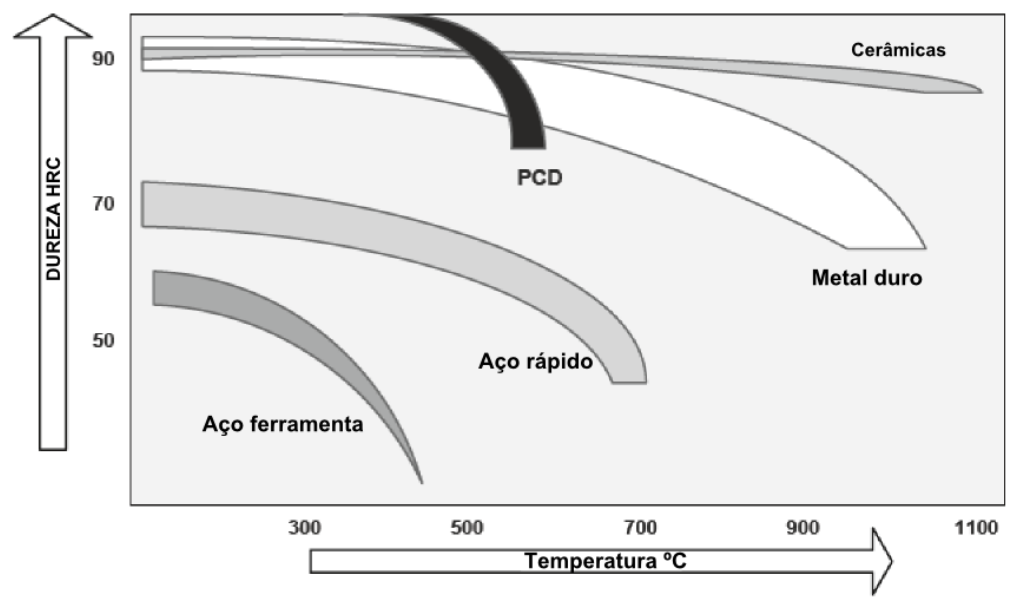

Figura 6 - Relação dureza e tenacidade para diferentes materiais de ferramentas. Fonte: [31].

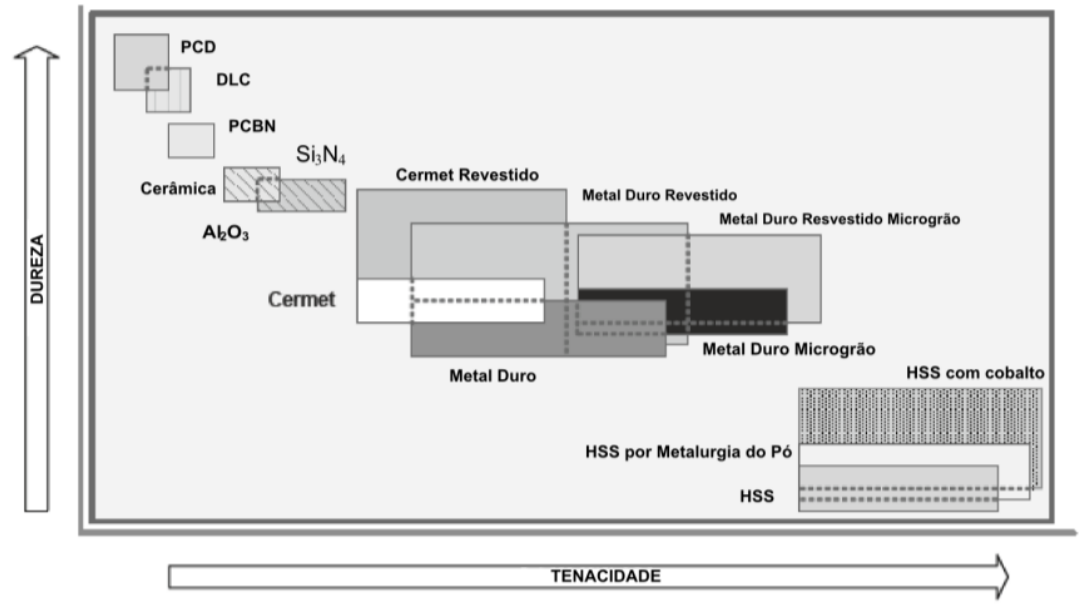

Na usinagem de materiais endurecidos é necessário que as ferramentas utilizadas sejam cuidadosamente fixadas na máquina. Deve-se maximizar a rigidez do sistema reduzindo-se todas as saliências, o com- 
primento da ferramenta e a sua extensão, e também eliminar calços e espaçadores [24].

\subsection{Parâmetros de corte}

Os parâmetros de corte utilizados na usinagem de materiais são grandezas que devem ser ajustadas na máquina de acordo com o material da ferramenta e da peça a ser trabalhada. O movimento de avanço $f$ (Figura 7), juntamente com o movimento de corte, origina o corte do material e a obtenção de cavacos. O movimento de avanço pode resultar de diferentes movimentos como o de avanço principal e movimento lateral [32]. O avanço de usinagem é quantificado no percurso a cada volta da ferramenta (mm/rot.) ou pelo deslocamento por minuto $(\mathrm{mm} / \mathrm{mim})$.

A profundidade axial de corte $a_{p}$ é a profundidade de penetração da ferramenta na peça, medida numa direção perpendicular ao plano de trabalho. A profundidade radial de corte $a_{e}$ é a penetração da ferramenta em relação à peça medida no plano de trabalho e numa direção perpendicular à direção de avanço (Figura 7).

A penetração de avanço $a_{f}$, é grandeza de penetração da ferramenta, medida no plano de trabalho e na direção de avanço.

Figura 7 - Parâmetros de profundidade de corte $\left(a_{p}\right)$, profundidade radial $\left(a_{e}\right) \mathrm{e}$ direção de avanço $(f)$.

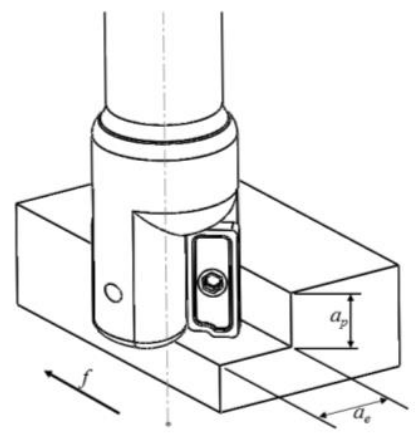

\subsection{Força de usinagem}

As forças presentes durante o fresamento são diretamente influenciadas pelos parâmetros de corte e geometria das ferramentas, e o 
correto emprego dos mesmos é de vital importância para alcançar os resultados de usinagem desejados.

As componentes da força de usinagem são resultado da remoção de cavacos. A variação da interferência geométrica entre a ferramenta e a peça e em decorrência da rotação da ferramenta a força de usinagem apresenta uma flutuação na sua direção. $O$ esforço sobre a face tende a ser principalmente de compressão, embora alguma tensão de cisalhamento seja observada. A tensão de compressão tende a ocorrer mais próximo do gume principal [33].

O objetivo de aperfeiçoar a geometria do gume consiste em melhorar a sua qualidade, buscando reduzir o desgaste. Algumas ferramentas especiais, o gume é preparado por retificação para melhorar a qualidade da superfície e aumentar o tempo de vida da ferramenta. Isto também influencia a formação do cavaco, podendo-se reduzir as forças de corte [34].

No fresamento há influência nas forças dependendo da estratégia de corte, se for fresamento concordante ou discordante. $\mathrm{O}$ fresamento discordante ocorre quando o gume entra em contato com a peça na menor área do cavaco e, gradualmente, devido ao movimento, a seção do cavaco aumenta até seu valor máximo. Já no fresamento concordante o gume toca a peça com o máximo valor da seção e tende ao final do corte para uma seção de menor valor, como mostrado na Figura 8.

Figura 8 - Fresamento concordante (esq.) e discordante (dir.). Fonte: [34].

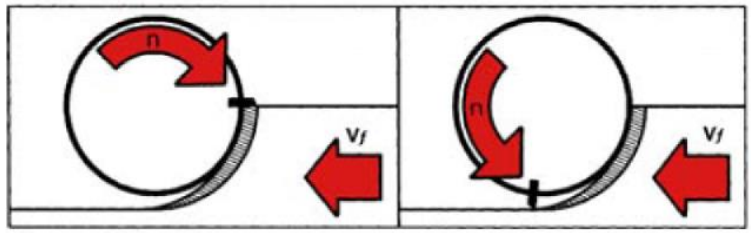

\section{$2.9 \quad$ Trajetórias de corte}

Existe um número elevado de estratégias que podem ser utilizadas para produzir uma cavidade, e cada estratégia apresenta vantagens e desvantagens [35]. Considerando o diâmetro da ferramenta de corte e as fronteiras de contornos do material a ser removido, aplica-se as trajetórias paralelas em um sentido e paralela ao perfil e espiral [36]. Trajetórias trocoidais também podem ser utilizadas, as quais combinam movimento circular uniforme e movimento linear uniforme [37].

Usando-se o mesmo material e ferramenta, as trajetórias ziguezague e paralela ao perfil consomem uma quantidade reduzida de energia 
para a obtenção da peça final, e relacionam-se com a rugosidade $R_{a}$ e o tempo de usinagem conforme mostrado na Figura 9 [65].

Figura 9 - Consumo de energia e rugosidade $R_{a}$ para diferentes trajetórias de usinagem. Fonte: [65].

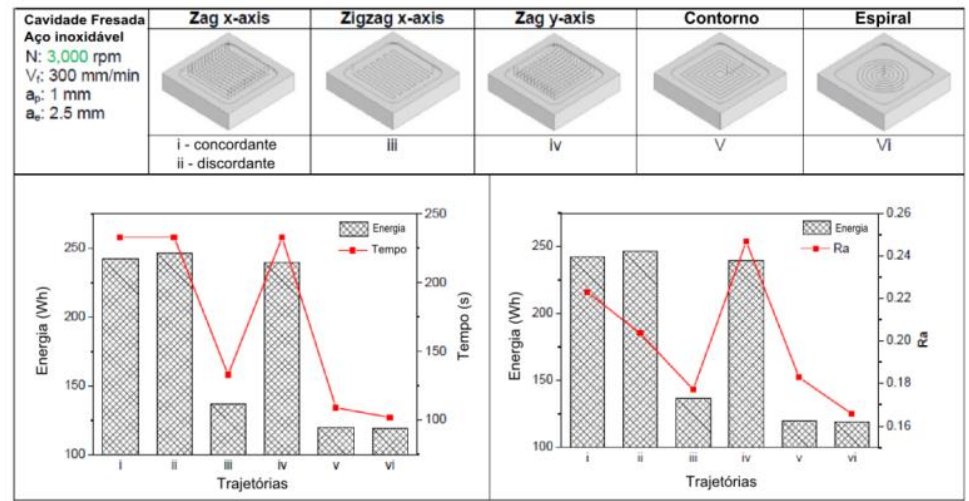

A trajetória trocoidal é definida como a combinação de um movimento circular uniforme com um movimento linear uniforme (Figura 10), com o percurso gerando uma curva cinemática chamada trocoide [37].

Figura 10 - Caminho da trajetória trocoidal no fresamento frontal. Fonte: [66].

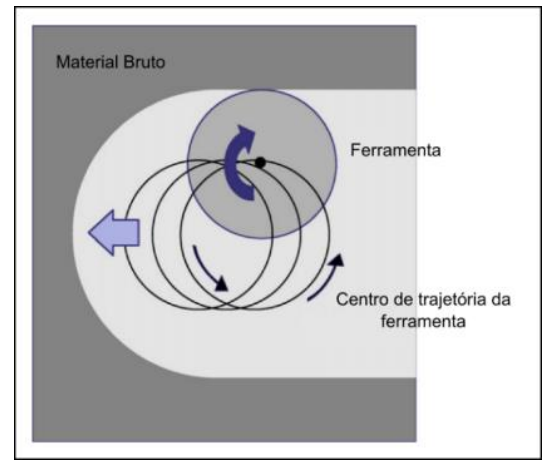

O principal objetivo das estratégias trocoidal é a criação de um caminho de ferramenta que evite corte concordante e discordante durante a usinagem e de imersão total da ferramenta no material, viabilizando uma profundidade radial máxima constante [66].

As estratégias para corte de peças prismáticas se dão por meio de informações geométricas de um modelo da peça a ser fabricada, onde 
os cálculos do caminho da ferramenta baseiam-se nas descrições dos volumes de material a serem usinados. Requisitos de qualidade dos produtos como, por exemplo, as tolerâncias dimensionais e as rugosidades superficiais, devem ser consideradas bem como nos modelos do processo [38].

Embora na maioria dos métodos de geração de caminho de ferramenta sejam utilizados segmentos de reta para definir a movimentação da ferramenta, a interpolação dos percursos de ferramenta gerados com curvas polinomiais também é realizada. O uso de curvas polinomiais reduz o tempo de usinagem quando o percurso da ferramenta é transformado para os movimentos dos eixos da máquina, diminuindo a quantidade de memória necessária do CNC.

A quantidade de pontos centrais de corte (CC) (Figura 11) decorre do diâmetro da ferramenta e dos passes da estratégia de usinagem. Em geral, com uma quantidade maior de pontos CC, obtém-se uma superfície mais precisa e com ondulações menores. Mas, por outro lado, ocupa-se mais memória além de ter-se um tempo de usinagem mais longo [39].

Figura 11 - Pontos centrais de corte para diferentes trajetórias.

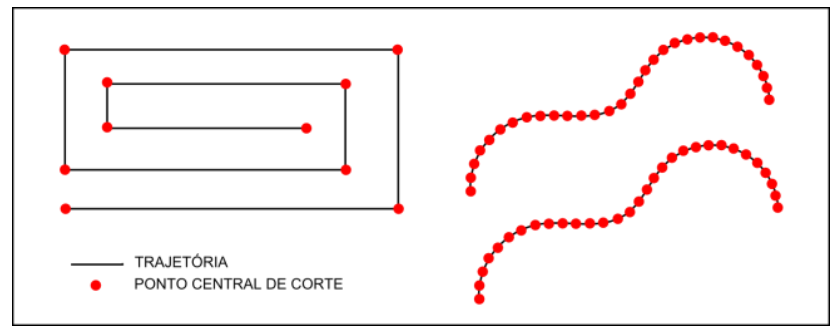

\subsection{Aços endurecidos e aços ferramenta}

Os aços ferramenta são aços que em sua estrutura apresentam alto teor de carbono, normalmente entre 0,6 a 1,4\%p, são os mais duros e resistentes porem menos dúcteis entre os aços carbonos. Usualmente utilizados em condição endurecida, especialmente resistente ao desgaste e abrasão [40].

Aos aços de alto carbono geralmente são adicionados elementos de liga como cromo, vanádio, tungstênio e molibdênio, de maneira a formar compostos à base de carbonetos [40].

As propriedades mecânicas de resistência ao desgaste dos aços da série D (aços para trabalho a frio) dependem da qualidade do aço 
ferramenta utilizado, e relacionam-se diretamente à dispersão dos carbonetos em sua microestrutura. Os efeitos dos carbonetos afetam a usinabilidade dos aços ferramenta. A presença destes elementos influencia ainda no desempenho do material em seu trabalho de corte, conformação ou puncionamento. Outro aspecto é o aumento do custo de manufatura de matrizes em que o material contenha a presença de carbonetos [41].

Os aços de trabalho a frio são classificados quanto ao seu teor de carbono, a divisão ocorre em três grupos com relação ao seu teor de carbono em peso, onde no primeiro grupo estão os aços de trabalho a frio com $0,4 \%$ a $0,7 \%$ de carbono, no segundo grupo estão os aços que tem entre $0,8 \%$ a $1,3 \%$ de carbono e por sua vez os aços do terceiro grupo são as que contem percentual de carbono superior a 1,5\%. Estes aços têm distinção quanto às faixas de dureza, processo de obtenção e tipo de carboneto, de acordo com as suas aplicações [42].

Matrizes de trabalho a frio são utilizadas principalmente para deformar metais à temperatura ambiente, incluindo os seguintes processos: perfuração, estampagem e extrusão a frio. Os moldes geralmente sofrem alta pressão e impacto, e a temperatura é normalmente inferior a $300^{\circ} \mathrm{C}$. Assim, as propriedades desejadas do aço devem ser a alta dureza, resistência ao desgaste, e capacidade de endurecimento [43].

\subsection{Avaliação de superfícies usinadas}

$\mathrm{O}$ processo de acabamento refere-se a qualquer processo pelo qual a superfície de um material é alterada visando alcançar os requisitos de projeto. A superfície pode ser alterada por meio mecânico, químico, eletroquímico ou fotoelétrico para produzir uma superfície com a textura, aparência, e resistência à corrosão desejada [44].

Integridade da superfície é a combinação de todos os elementos que descrevem as condições existentes na região próxima abaixo da superfície acabada de uma peça. A integridade da superfície tem dois aspectos: (a) a topografia da superfície que descreve a rugosidade, isto é, a sua interface com o ambiente; (b) a metalurgia, que corresponde à natureza das camadas abaixo da superfície (Figura 12). A integridade da superfície é influenciada pelo impacto de processos de fabricação sobre as propriedades do material da peça [45]. 
Figura 12 - Zonas de estudo para caracterização de superfícies. Fonte: [45].

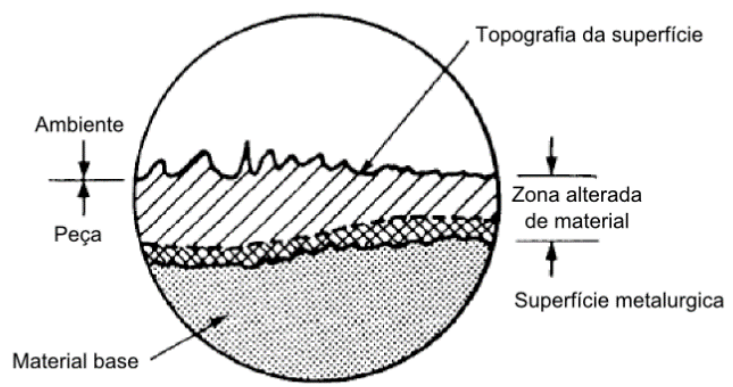

A rugosidade sofre influência de vários elementos presentes na usinagem, incluindo: a geometria e o material da ferramenta de corte, material da peça, rigidez da máquina-ferramenta, condições de corte [12].

A rugosidade média $R_{a}$ (Figura 13) é um parâmetro de controle do processo, uma vez que a sua alteração indica a ocorrência de alteração no processo de fabricação. Ela é um parâmetro muito utilizado pela indústria e está disponível nos rugosímetros mais simples e baratos. É caracterizado pelo desvio médio aritmético dos valores de afastamentos absolutos em relação à linha média dentro do comprimento total de medição da medição [12].

Figura 13 - Parâmetro de rugosidade $R_{a}$. Fonte: [46].

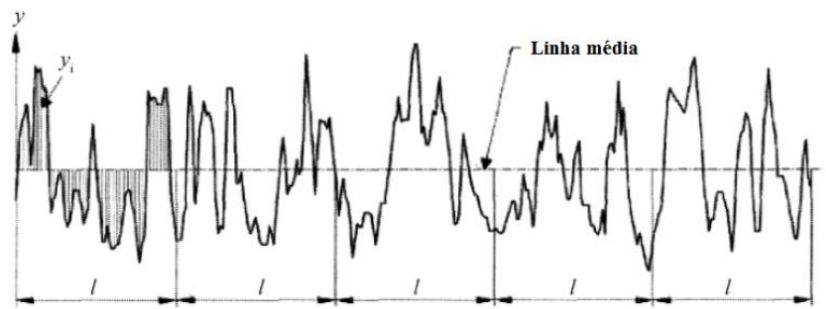

Outro parâmetro utilizado para verificar a qualidade superficial é a rugosidade total $R_{t}$. Este parâmetro é a máxima altura do pico ao vale identificado no comprimento de avaliação, sendo muito sensível a grandes desvios da linha média e riscos [46]. 
Dentre outros parâmetros utilizados para caracterização da superfície, o fator de assimetria ("skewness") $\left(R_{s k}\right)$ é o que expressa à simetria de picos e vales de uma superfície, utilizando a linha média como centro, podendo ser positivo ou negativo (Figura 14). Tem-se $R_{s k}>0$ quando a assimetria é para baixo em relação à linha média, enquanto tem-se $R_{s k}<0$ quando a assimetria é para cima em relação à linha média. Este é um parâmetro importante para aplicações tribológicas, visando preferivelmente à redução do desgaste.

Figura 14 - Parâmetro de assimetria da superfície ("Skewness"). Fonte: [46].
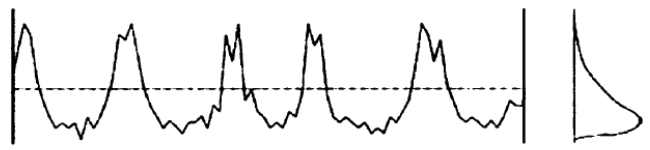

$$
R_{\mathrm{sk}}>0
$$
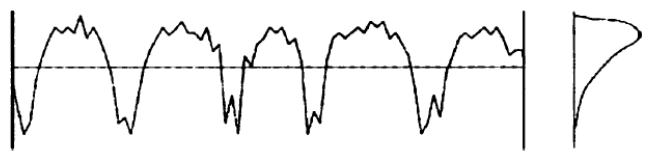

$R_{\mathrm{sk}}<0$

Cada tipo de ferramenta de corte deixa marcas únicas na superfície usinada. A direção e configuração dominante do padrão de superfície são influenciadas pelo método de usinagem. Os resultados práticos da textura da superfície serão afetados por uma série de fatores, os quais são relacionados com a ferramenta de corte, a máquina ferramenta e a peça. Em particular, a estabilidade estática e dinâmica do sistema de usinagem influencia diretamente a qualidade da textura da superfície [47].

Outro fator importante para a qualidade da superfície usinada são as condições de corte aplicadas durante a fabricação. Estas condições influenciam a integridade superfície usinadas como mostra a Figura 15 , ilustrando a relação entre condição suave e excessiva e a respectiva integridade obtida. 
Figura 15 - Relação das condições de corte e integridade superficial. Fonte: [47].

\begin{tabular}{|c|c|c|}
\hline Geral & Ferramenta Afiada & Ferramenta Arredondada \\
\hline 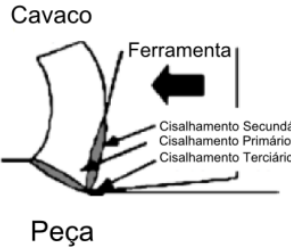 & Tipicamente com raio de 8 mm & 28 \\
\hline \multirow{2}{*}{$\begin{array}{l}\text { Condições de usinagem = } \\
\text { Integridade da superfície= }\end{array}$} & Usinagem favorável & Abusiva \\
\hline & Alta & Baixa \\
\hline
\end{tabular}

Para a elaboração do plano de processo para usinar uma peça, é necessário o conhecimento da capacidade de cada processo para atingir as metas colocadas no projeto do componente. Na Figura 16 são apresentadas as faixas de aplicação usuais e também menos frequentes de valores de rugosidade $R_{a}$ para diferentes processos de usinagem.

Figura 16 - Faixas de rugosidade $R_{a}$ obtidas para diferentes processos de usinagem. Fonte: ASME/ANSI B46.1-1985 apud [47].

Rugosidade média $R_{\mathrm{a}} \mu \mathrm{m}$

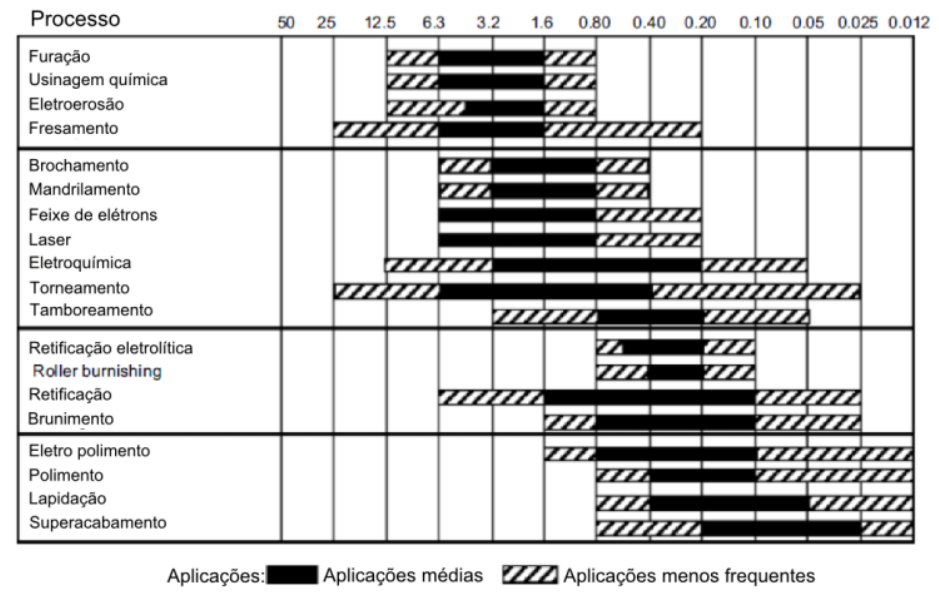




\subsection{Sustentabilidade}

Nos dias atuais é unânime a busca por um desenvolvimento sustentável para toda a sociedade, mesmo sabendo-se que este é um grande desafio. Porém, há divergências significativas sobre o significado específico dos termos relacionados à sustentabilidade. Este cenário acaba por gerar uma problemática tendo em vista a proliferação de informações sobre o tema, dificultando identificar e selecionar corretamente os conhecimentos efetivamente relevantes [48].

Uma grande quantidade de informações referentes à sustentabilidade está disponível para pesquisa, porém é necessário compreender o ponto de vista específico no qual a sustentabilidade será mensurada [49]

$\mathrm{O}$ conceito de sustentabilidade normalmente adotado é expresso no relatório de Brundtland, documento que foi nomeado como "Nosso Futuro Comum" (Our Common Future), publicado em 1987, que aponta que "o desenvolvimento sustentável é o desenvolvimento que satisfaz as necessidades do presente sem comprometer a capacidade das gerações futuras satisfazerem as suas próprias necessidades" [50].

Os conceitos de sustentabilidade e gestão ambiental vêm sendo definidos desde a Conferência de Estocolmo em 1972, a qual relata princípios da relação do homem com o meio ambiente. É importante citar a Comissão Mundial sobre Meio Ambiente e Desenvolvimento (1983) e a Rio92, todas retratando princípios básicos a serem observados para um desenvolvimento sustentável [49]. O trabalho de Elkington [51] foi pioneiro na análise sustentável visando ganhos no âmbito econômico, porém relacionados aos impactos ambientais e sociais, definido como "triple bottom line", conhecido como "tripé da sustentabilidade".

A preocupação sincera para o futuro é certamente um fator que motiva muitos que fazem uso frequente da palavra "sustentável". Mas há casos onde se suspeita que a palavra seja usada descuidadamente, talvez como se existisse a crença de que o uso frequente do adjetivo "sustentável" é suficiente para criar uma sociedade sustentável. Além disto, a utilização do termo "sustentabilidade" por algumas empresas e instituições ocorre muitas vezes de forma equivocada quanto ao desenvolvimento das atividades das mesmas [52].

A indústria transformadora é um evento de negócios e, como tal, os engenheiros são bem versados na determinação do valor econômico das soluções de engenharia para a fabricação. Medir o desempenho ambiental e social é uma tarefa desafiadora. Material e energia são insumos necessários em processos e sistemas de manufatura, enquanto resíduos e emissões, que são geralmente classificados como saídas de 
um sistema de manufatura são entradas para outros sistemas industriais e naturais, onde o seu impacto é sentido social, ambiental e economicamente (Figura 17) [53].

Figura 17 - Papel da manufatura industrial em um sistema de sustentabilidade. Fonte: [53].

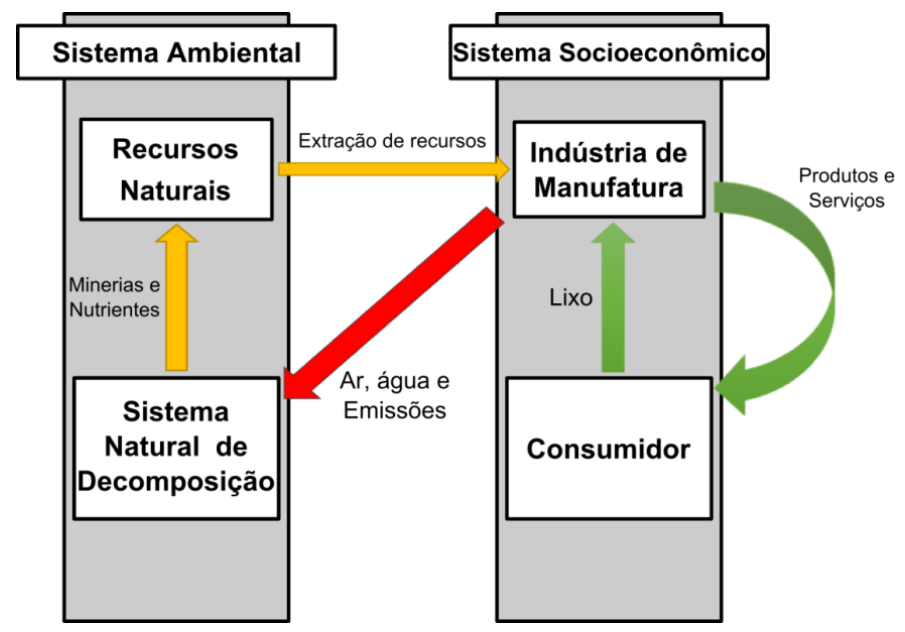

\subsection{Sustentabilidade na usinagem}

Para realizar uma análise sustentável na manufatura moderna, é necessário ter a correta interpretação do conceito de sustentabilidade. Para definir os critérios para avaliação de sustentabilidade é essencial escolher o âmbito considerado (ambiental, econômico e/ou social).

O departamento de comércio dos EUA define sustentabilidade na manufatura como sendo a "criação de produtos fabricados que utilizam materiais e processos, minimizem os impactos ambientais negativos, conservando energia e recursos naturais, e sejam seguros para os funcionários, comunidades e consumidores, e economicamente sadio" [54].

Como os impactos ambientais da indústria transformadora são muito elevados, incluindo emissões e resíduos, a produção sustentável tem atraído enorme atenção nos últimos anos como uma estratégia global para reduzir o impacto ambiental e melhorar o desempenho econômico da indústria transformadora [55]. 
Os seguintes critérios podem ser diretrizes e soluções importantes para os problemas relacionados com produtos, serviços, processos e sistemas [56]:

- Uso de recursos renováveis;

- Uso de recursos regionais;

- Nível de eficiência em produtos e processos;

- Utilização de operações como a reutilização e a reciclagem;

- Grau de adaptação e compatibilidade de tecnologias;

- Nível de tolerância a falhas e prevenção de riscos dentro dos sistemas.

Critérios e princípios quanto à sustentabilidade descrita nos diversos encontros internacionais mediante tratados, são muito amplos e aplicáveis a todos os níveis das organizações. Porém, para aplicá-los em nível de processo é preciso identificar e mensurar os fenômenos e recursos utilizados.

Lu et al. [57] apresentaram um quadro para o desenvolvimento de métricas de produção sustentável, além das inter-relações e interações potenciais entre métricas. Várias dessas métricas estão listadas na Tabela 1 para os processos de fabricação sustentáveis. As métricas abrangem aspectos econômicos, ambientais e sociais, e medem as entradas e saídas de um processo de fabricação em nível de estação de trabalho ou linha de produção [53].

Tabela 1 - Potenciais métricas do processo de fabricação sustentável com foco na usinagem. Fonte: [57].

Tipo de métrica de Processo

Exemplo

\begin{tabular}{|c|c|}
\hline \multirow{3}{*}{ Impacto Ambiental } & Emissão dos gases de efeito estufa (tCo2 eq./unid.) \\
\hline & Proporção de energia renovável utilizada \\
\hline & Consumo total de água \\
\hline \multirow{3}{*}{ Consumo de Energia } & Uso de energia na linha de produção (kWh/unid.) \\
\hline & Uso de energia para trabalhos de manutenção \\
\hline & Consumo de energia para manuseio de materiais \\
\hline \multirow{3}{*}{ Custo Econômico } & Custo de trabalho (\$/unid.) \\
\hline & Custo Energia \\
\hline & Custo Manutenção \\
\hline \multirow{3}{*}{ Segurança do trabalhador } & Exposição a materiais tóxicos/corrosivos (acidente/pessoa) \\
\hline & Taxa de acidentes \\
\hline & Quase acidentes \\
\hline \multirow{3}{*}{ Saúde do Trabalhador } & Contaminação química do trabalhador $\left(\mathrm{mg} / \mathrm{m}^{3}\right)$ \\
\hline & Nível de névoa/pó \\
\hline & Índice de carga física \\
\hline \multirow{3}{*}{ Gestão de Resíduos } & Massa de materiais descartados (kg/unid.) \\
\hline & Taxa de materiais reusados \\
\hline & rção da reciclagem de cavacos e sucata \\
\hline
\end{tabular}


Os cavacos gerados na usinagem podem ser reciclados e, em alguns casos, são altamente valiosos. Porém, deve-se minimizar a quantidade de cavacos, usando-se, por exemplo, a geometria da peça bruta próxima da geometria da peça desejada. Assim, o tempo de uso das ferramentas é menor, e também o uso de fluidos lubrirefrigerantes, tendo-se assim um ganho do ponto de vista econômico e ambiental [53].

Outra questão para um melhor desempenho ambiental e social é relacionado à utilização de fluidos de corte, por meio de abordagens de usinagem a seco, MQL (mínima quantidade de lubrificante) e fluidos alternativos (por exemplo, nitrogênio líquido) [53].

$\mathrm{O}$ consumo de energia no processamento de materiais é um fator importante no âmbito da manufatura sustentável. No nível de equipamento tem-se o exemplo na Figura 18, que mostra a energia consumida por equipamentos de usinagem para o seu funcionamento, sendo que somente $15 \%$ do consumo total são utilizados para o corte do material [58].

Figura 18 - A utilização de energia em máquinas de usinagem na Toyota. Fonte: [58].

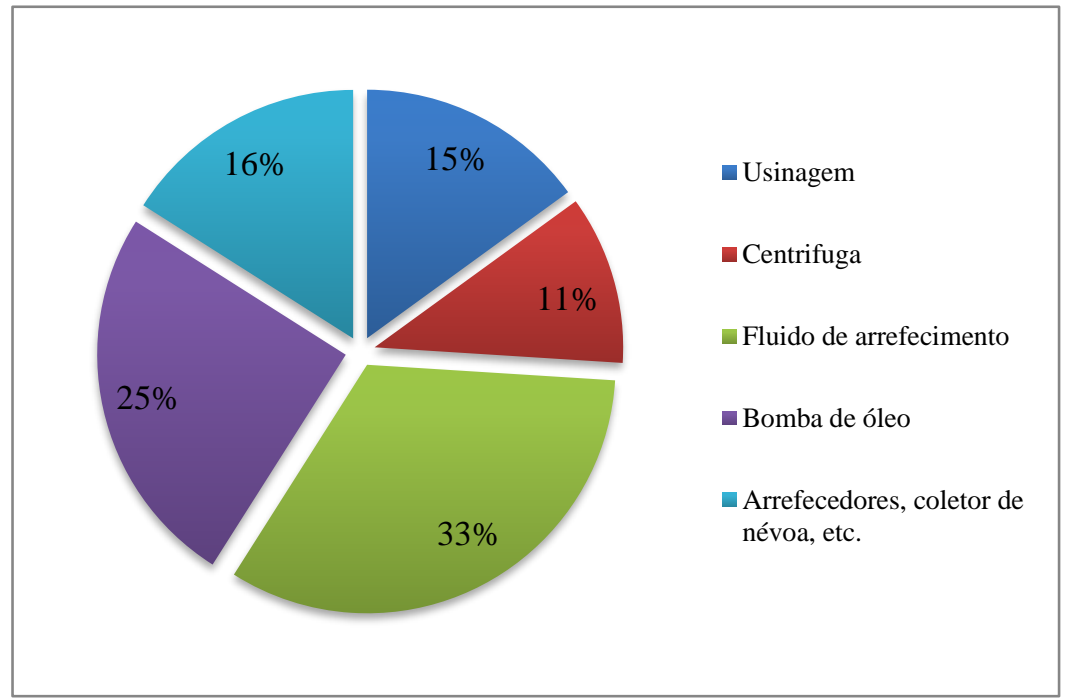

A preocupação com o consumo de menores quantidades de energia para a fabricação de produtos também é contemplada na produção das ferramentas de usinagem. A reciclagem dos insertos de metalduro, atualmente, é uma alternativa ambientalmente correta e lucrativa. A produção de ferramenta nova com a utilização de metal-duro recicla- 
do resulta em uma economia de $70 \%$ no consumo de energia se comparado à utilização de ferramentas completamente novas obtidas de matérias-primas em seu estado virgem. Em termo de emissões tem-se uma redução de $40 \%$ de $\mathrm{CO}_{2}$ na atmosfera com a produção de ferramentas a partir do metal-duro reciclável, como mostrado na Figura 19 [59].

Figura 19 - Relação do consumo de energia e redução de emissões com a reciclagem do metal duro na fabricação de novas ferramentas de corte. Fonte: [59].

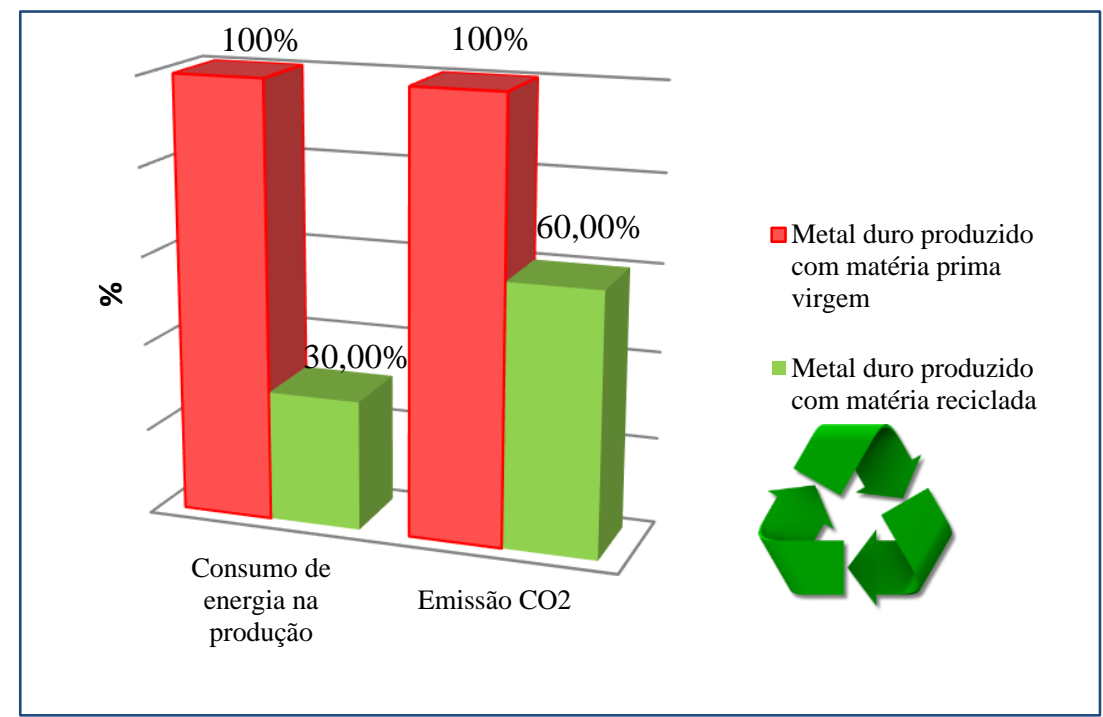

A fim de assegurar a competitividade na fabricação, deve haver um equilíbrio entre as dimensões econômica, ambiental e social. Assim, há um conjunto complexo de interdependências entre os parâmetros que afetam o resultado final do processo de usinagem [60].

\subsection{Avaliação do processo de usinagem no âmbito da sustentabi- lidade.}

Com a preocupação do mundo moderno quanto a questões ambientais, sociais e econômicas, tem se estudado em diversas áreas das ciências maneiras sustentáveis de utilização de recursos sem o esgotamento dos mesmos, e sem comprometer as necessidades das gerações futuras. No desenvolvimento dessa pesquisa, no âmbito da usinagem de aços endurecidos, realiza-se a análise no que tange as dimensões econômica, social e ambiental. 
Para isto, utiliza-se parâmetros quantitativos e qualitativos, observando-se diretrizes para um relato de sustentabilidade elaborados pela GRI (Global Report Initiative) disponíveis nas partes 1 e 2 [69] [70], indicadores de sustentabilidade na manufatura descritos pela OECD (Organização para a Cooperação e Desenvolvimento Económico) [71], além de identificar métricas contidas em trabalhos disponíveis na literatura como Araujo [72], Bhanot [60], Dornfeld [54], Lu et al. [57] e Haapala [53].

As normas ISO NBR 14001 [73] e 14031 [74] descrevem deveres e métricas a serem adotados para que uma organização tenha sua certificação de sistema de gestão ambiental. Pode-se adicionar outras diretrizes resultantes de encontros internacionais ao longo dos anos, adaptando-as e aplicando-as na avaliação da usinagem. A Figura 20 mostra a organização das diretrizes e métricas relacionadas à sustentabilidade aplicadas na avaliação do processo de usinagem.

Figura 20 - Avaliação do processo de usinagem segundo diretrizes e métricas.

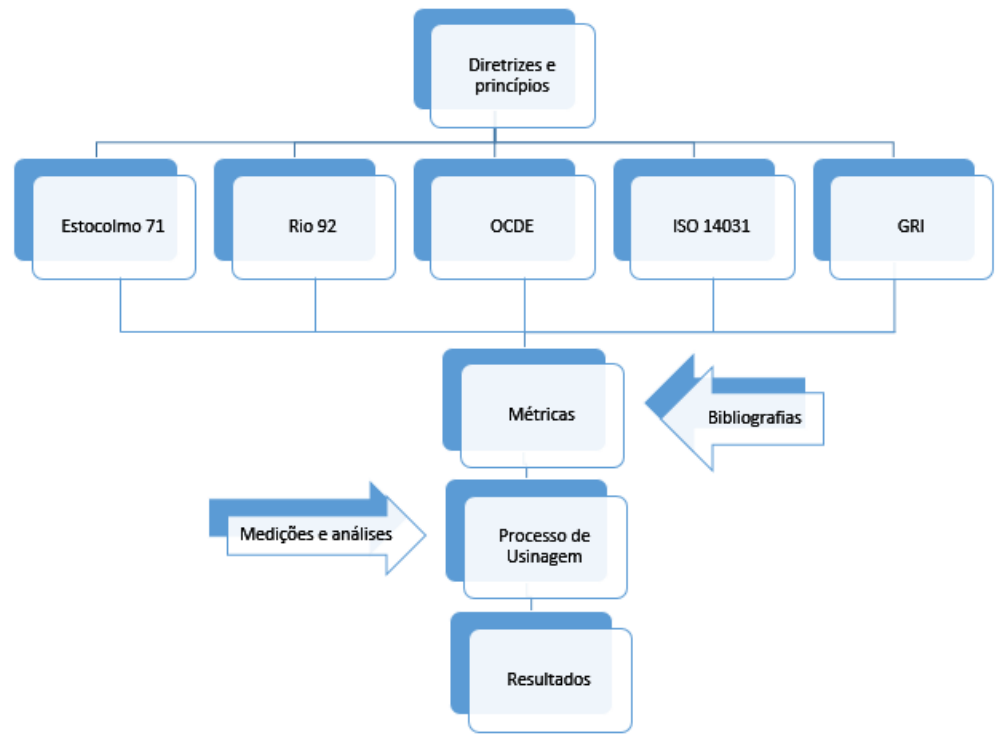

Uma dificuldade encontrada para o relato da sustentabilidade em nível de processo de fabricação é que as convenções descrevem princípios e diretrizes no nível da organização como um todo, não com enfoque no processo produtivo. Porém, na literatura estão disponíveis trabalhos em que o foco está nos processos de manufatura, apresentando 
metodologias de avaliação sustentável que podem ser aplicadas por outros pesquisadores.

Dentre os modelos de avaliação de sustentabilidade tem-se a existência de diversos termos e diferentes técnicas para alcançar o objetivo da avaliação, necessitando-se de uma integração e paridade entre os modelos descritos [75].

Os processos de mensuração da sustentabilidade são divididos em fases determinadas de acordo com cada modelo. Deve-se nesse caso identificar os indicadores como partes do processo, de maneira a analisar e diagnosticar o processo de maneira adequada [72].

Araujo [72] lista modelos de medição da sustentabilidade classificando-os quanto à sua dimensão e direcionado à área, buscando mostrar na dimensão do tripé da sustentabilidade se há modelos anteriores que tratam da manufatura. Ele propõe um modelo de avaliação da sustentabilidade direcionado aos processos de fabricação (retificação e torneamento) iniciando com a definição do escopo e objetivos, identificando os aspectos, selecionando os indicadores, realizando a coleta de dados, avaliando a sustentabilidade do processo e, por fim, sintetizando os resultados obtidos.

Lu et al. [57] abordam as métricas de sustentabilidade a partir da concepção do produto voltado para a fabricação com a medição das entradas e saídas do processo de usinagem relacionando a seis elementos do processo de manufatura: (a) impactos ambientais, (b) custos de manufatura, (c) consumo de energia, (d) gestão de resíduos, (e) segurança operacional e (f) saúde pessoal, e verificando a interrelações e potencial interações entre as métricas nas diferentes dimensões.

Dentro do referencial teórico apresentado estão os assuntos abordados pela pesquisa em questão, primeiramente estão relatados conhecimentos com definições dos processos de fabricação, com enfoque na usinagem por fresamento descrevendo os princípios e ferramentas empregados no processo. Também foram apresentadas algumas inferências quanto aos aços endurecidos para trabalho a frio. Outra questão contemplada é a usinagem CNC, tendo sido citadas ferramentas de auxílio computacional dentro do processo produtivo, as quais são imprescindíveis no cenário atual do planejamento de processo e fabricação.

Ainda nesta revisão foram apresentados conceitos de sustentabilidade, direcionados para os ganhos no âmbito ambiental, econômico e social, complementados com informações relatando a sustentabilidade no processo de usinagem.

No próximo capítulo serão descritos os materiais e métodos avaliando a tecnologia de usinagem de aço endurecido, e também será 
proposto um método de identificação e exposição dos aspectos referentes ao tripé da sustentabilidade. 


\section{MATERIAIS E MÉTODOS}

A realização dos experimentos foi executada nas dependências da Universidade Federal de Santa Maria (UFSM), no Laboratório de Usinagem por Comando Numérico do Colégio Técnico de Santa Maria. Nas seções a seguir são descritos os equipamentos e a metodologia experimental empregadas na pesquisa.

\subsection{Equipamentos}

\subsubsection{Máquina Ferramenta}

A máquina-ferramenta utilizada na realização dos ensaios de usinagem foi o centro de usinagem Romi D600, com CNC General Eletric FANUC Oi-MC. Este centro de usinagem com três eixos, e suas principais características descritas pela Tabela 2.

Tabela 2 - Especificações do centro de usinagem ROMI D600.

\begin{tabular}{|cc|}
\hline \multicolumn{2}{|c|}{ Especificações } \\
\hline Curso da mesa nos eixos " $x$ " e " $y$ " & $600 \mathrm{~mm} \mathrm{X} \mathrm{530} \mathrm{mm}$ \\
\hline Curso do eixo "z" & $580 \mathrm{~mm}$ \\
\hline Rotação máxima Spindle & $7500 \mathrm{RPM}$ \\
\hline Potência do motor principal & $15 \mathrm{~kW}$ \\
\hline Avanço rápido eixos “ $x$ ", " $y$ ", " $z "$ & $30 \mathrm{~m} / \mathrm{min}$ \\
\hline Posicionamento dos eixos & $0,006 \mathrm{~mm}$ \\
\hline
\end{tabular}

\subsubsection{Rugosímetro}

A medição das superfícies usinadas foi feita utilizando-se o rugosímetro digital marca Instrutherm, modelo RP 200 (Figura 21). Foi utilizado o filtro de Gauss nas medições e cut-off de $0,8 \mathrm{~mm}$ com comprimento de amostragem de $5 \mathrm{~mm}$, e selecionada a faixa de medição \pm 40 $\mu \mathrm{m}$.

Figura 21 - Rugosímetro RP-200 utilizado na medição das superfícies usinadas.

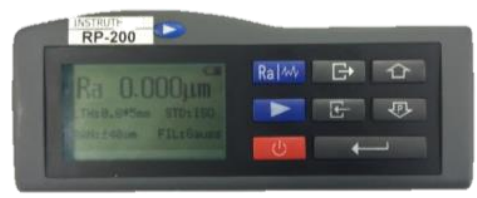




\subsubsection{Luxímetro e medidor de emissão acustica}

A intensidade da luminosidade foi medida com o Luxímetro SKLD-400 da fabricante Skill-Tec, o qual tem duas funções de medição: em lux e footcandle. Para a obtenção dos resultados de luminosidade do ambiente também foi feita a conexão com computador para arquivar os resultados obtidos no transcorrer dos testes para posterior análise. $\mathrm{O}$ software utilizado foi Light Meter, disponibilizado juntamente com a aquisição do equipamento.

O decibelímetro utilizado para captação da emissão acústica do ambiente durante os testes de usinagem foi o ITDEC-4080, da Instrutemp. O mesmo é fabricado em conformidade com os requisitos da norma IEC 61672-1:2003 para um instrumento de Classe 2. O aparelho possui diversas características que permitem medições do nível sonoro sob uma variedade de condições.

$\mathrm{O}$ instrumento foi conectado ao computador por meio de entrada USB, e captados os resultados com o software SLMM. O software adquire os dados de emissão sonora a cada um segundo armazenando-os para posterior análise.

Na Figura 22 estão mostrados os equipamentos durante o monitoramento do processo de usinagem para o levantamento dos dados.

Figura 22 - Monitoramento da emissão acústica, luminosidade do ambiente e consumo de energia pela máquina ferramenta com aquisição dados por meio de softwares e registro do datalog.

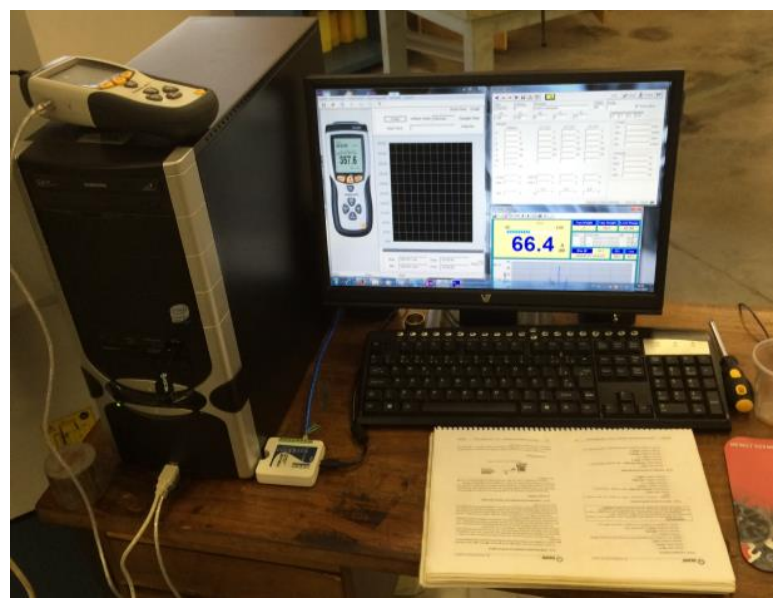




\subsubsection{Medidor de Energia}

Para captar a energia ativa consumida pela máquina-ferramenta, foi utilizado o transdutor de energia com sensor de corrente não invasivo Mult-K 120 (Figura 23), fabricante KRON. Esse equipamento possibilita a medição de até 44 parâmetros elétricos em sistemas monofásicos, bifásicos ou trifásicos (estrela/delta) de forma local (versão com display LCD) e/ou remota através da saída RS-485.

Figura 23 - Transdutor de energia MULTI-K 120 KRON.

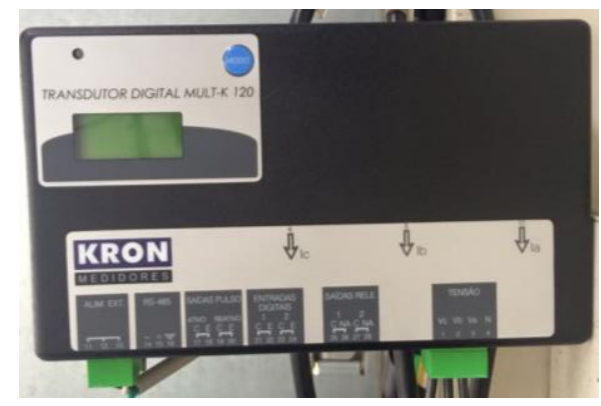

O transdutor foi posicionado na entrada de energia da máquina ferramenta, assim foi possível medir toda a energia utilizada para o funcionamento da mesma, exemplificado pela Figura 24. Optou-se por medir a consumo global do centro de usinagem para ter o real consumo e impacto gerado pela usinagem, não somente medindo a energia necessária para as movimentações dos eixos e fuso. Em máquinas CNC há um grande aparato tecnológico consumidor de energia, também presente sistema auxiliar de lubrificação que devem ser considerados para avaliar os impactos nos diferentes aspectos de estudo.

Figura 24 - Diagrama de ligação para a medição do consumo de energia.

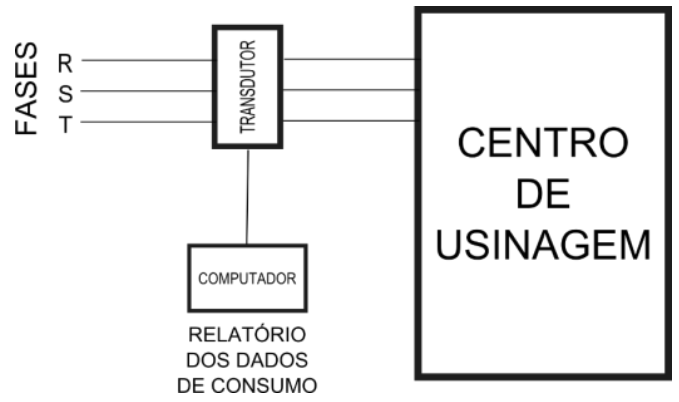


3.1.5 Microscópio para medição dos desgastes do gume

O microscópio STEMI SV8, da fabricante Zeiss, fui utilizado para a aquisição das imagens dos desgastes das ferramentas de corte, junto ao microscópio foi utilizado o sistema de captura de imagem da Leica EC3 ligado ao computador, no qual foram efetuadas as medições dos desgastes.

\subsubsection{Ferramenta de corte}

$\mathrm{O}$ experimento foi realizado com insertos de metal-duro classe VP15TF (ISO H10-H20), revestidos com $(\mathrm{Al}, \mathrm{Ti}) \mathrm{N}$, código segundo a ANSI AOMT123608PEER-H, os quais foram especificamente desenvolvidos para o corte de aços endurecidos. Com a finalidade de eliminar a camada mais externa do material após o tratamento térmico foi efetuado o desbaste com cabeçote de fresamento $90^{\circ}$ com insertos segundo a Figura 25a. O acabamento então foi feito com uma ferramenta também com corte de $90^{\circ}$, com diâmetro de $16 \mathrm{~mm}$ (Figura 25b).

Figura 25 - Inserto para acabamento e desbaste (a), ferramenta $\varnothing 16 \mathrm{~mm}$ utilizada no acabamento (b).

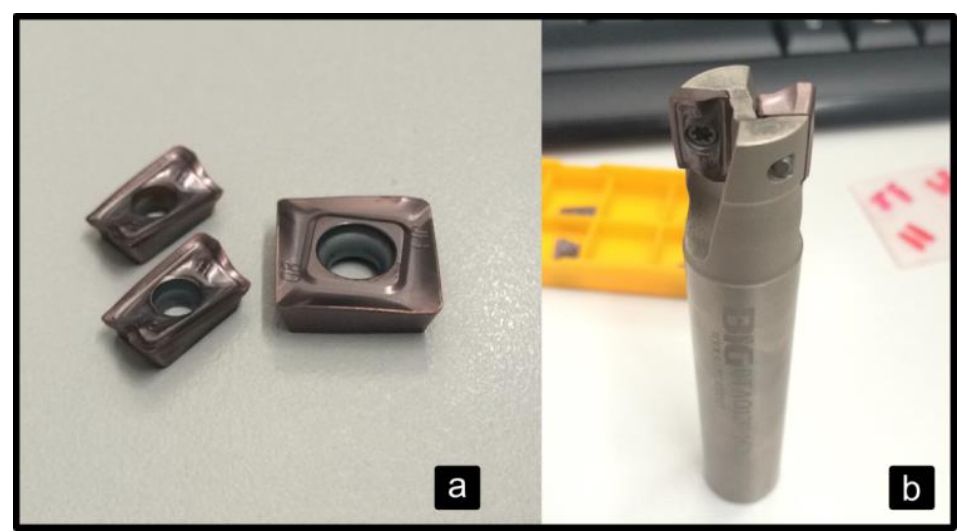

A escolha dos insertos de metal-duro foi feita após avaliar as possibilidades disponíveis no mercado, também seguindo publicações anteriores [16] [20] [24] [33]. Dois fatores foram considerados quanto à utilização do metal-duro: (a) o fator econômico se comparado com inserto de cBN (nitreto de boro cúbico), o qual é bem mais caro do que o metal-duro, (b) pela aplicação no fresamento, que tem característica de corte interrompido, sendo que o metal-duro tem maior tenacidade em comparação com o cBN. 
A avaliação das opções de ferramentas também se deu por meio da análise dos catálogos da Sandvik [61], Mitsubishi [62] e Kennametal [63], onde buscou-se verificar a disponibilidade de materiais de ferramentas e geometrias para a usinagem do aço SAE D6, que é o material considerado neste trabalho, conforme descrito na próxima seção.

\subsection{Material para ensaio}

Na realização dos experimentos foi usinado o aço SAE D6, com dureza entre 60 - 62 HRC. O material bruto foi tratado termicamente mediante os processos de têmpera e revenido. $\mathrm{O}$ certificado atestando a dureza do material utilizado nos ensaios está disponível no anexo A.

Este aço é utilizado no ramo da matrizaria de alto rendimento para corte de chapas, bem como cortes de precisão na produção de papel. Outras aplicações são em guias de máquinas, réguas e ferramentas em geral, onde exige-se máxima resistência à abrasão e estabilidade do gume de corte [64].

O material utilizado foi doado por uma empresa, e os dados de composição química, que é mostrada na Tabela 3, foram obtidas do catálogo técnico do fornecedor.

Tabela 3 - Composição química do aço SAE D6. Fonte [64].

\begin{tabular}{|c|c|c|c|c|c|c|c|c|c|}
\hline & $\mathbf{C}$ & $\mathbf{S i}$ & $\mathbf{M n}$ & $\mathbf{C r}$ & $\mathbf{M o}$ & $\mathbf{N i}$ & $\mathbf{V}$ & $\mathbf{W}$ & Outros \\
\hline $\begin{array}{c}\text { AISI/SAE } \\
\text { D6 }\end{array}$ & $2,10 \%$ & $0,40 \%$ & $0,40 \%$ & $12,00 \%$ & - & - & - & $0,70 \%$ & - \\
\hline
\end{tabular}

\subsection{Corpo de prova para ensaio}

A geometria dos corpos de prova usinados neste trabalho é mostrada na Figura 26, os quais têm $50 \mathrm{~mm}$ de comprimento, $50 \mathrm{~mm}$ de largura e $10 \mathrm{~mm}$ de profundidade. Eles foram obtidos a partir de barras chatas, com as cavidades usinadas em uma das faces. A profundidade de cada cavidade foi definida em $0,2 \mathrm{~mm}$ na operação de acabamento. 
Figura 26 - Modelo computacional e medidas do corpo de prova a ser fabricado.

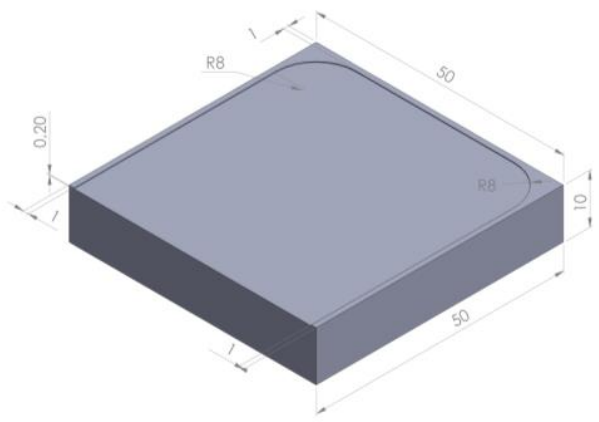

\subsection{Trajetórias para acabamento}

A trajetória de usinagem é uma das variáveis que influencia a qualidade do produto final. Foram escolhidas três diferentes trajetórias de corte após a observação da bibliografia disponível. As estratégias utilizadas para usinagem, as quais geram uma geometria de fundo plano, as quais são: (a) ziguezague; (b) paralela ao perfil; (c) trocoidal, como mostrado na Figura 27.

Figura 27 - Trajetória zigue zague (esquerda), paralela ao perfil (centro) e trocoidal (direita).
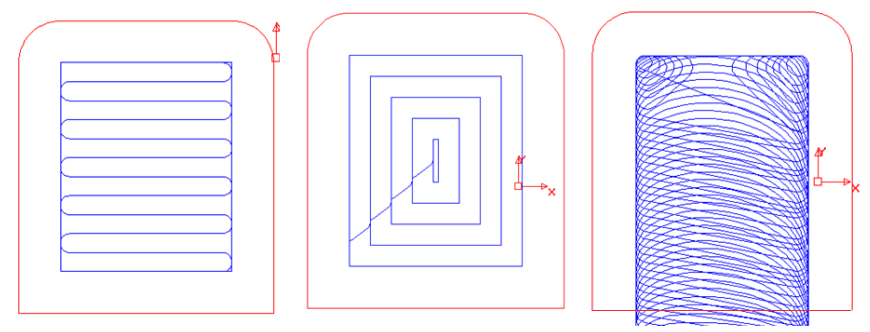

\subsection{Parâmetros de corte}

Dentre os parâmetros de corte, a velocidade de corte $\left(v_{c}\right)$ foi a variável alterada para a avaliação dos corpos de prova. Duas velocidades 
de corte foram empregadas na usinagem, e os valores utilizados foram obtidos com base na recomendação do fabricante, e pode-se comparar com estudo disponíveis na literatura como de Cavaler [67]. Os demais parâmetros de corte $\left(a_{p}, a_{e}\right.$ e $\left.v_{f}\right)$ foram fixados e igualmente repetidos em todos os experimentos.

Escolheu-se as seguintes velocidades de corte: (a) $60 \mathrm{~m} / \mathrm{min}$ $\left(v_{c 1}\right)$, a qual situa-se dentro da faixa recomendada pelo fabricante (entre 50 e $80 \mathrm{~m} / \mathrm{min}$ ); (b) $85 \mathrm{~m} / \mathrm{mim}\left(v_{c 2}\right.$ ), superior ao limite sugerido pelo fabricante [62], a qual foi utilizada com o intuito de examinar os resultados de acabamento e desgaste da ferramenta.

\subsection{Planejamento experimental}

O delineamento experimental segue os princípios descritos por Coleman e Montgomery [68] onde, para um experimento, são estabelecidas etapas para obter e tratar os dados, as quais são:

- Caracterização do problema;

- Escolha dos fatores de influência e níveis;

- Seleção das variáveis de resposta;

- Determinação de um modelo de planejamento de experimento;

- Condução do experimento;

- Análise dos dados;

- Conclusões e recomendações.

Para o delineamento foi aplicada a experimentação por blocos, em que cada cavidade do experimento foi tratada como um "indivíduo". Posteriormente à usinagem foram realizadas medições de rugosidade da peça e análise da ferramenta de corte.

A combinação dos fatores foi feita variando-se a velocidade de corte $\left(v_{c}\right)$ e as diferentes trajetórias descritas na seção 3.4. Tem-se assim seis combinações diferentes aplicáveis a cada corpo de prova e, para fim estatístico, são efetuadas quatro replicações de cada combinação totalizando 24 cavidades usinadas ao fim do experimento.

As combinações foram definidas de forma aleatória e descritas como mostrado na Tabela 4. 
Tabela 4 - Tratamentos aplicados aos corpos de prova.

\begin{tabular}{|lcc|}
\hline & Velocidade de Corte $\boldsymbol{v}_{\boldsymbol{c}}$ & Trajetória \\
\hline Combinação ZZ60 & $60 \mathrm{~m} / \mathrm{min}$ & Ziguezague \\
\hline Combinação PP60 & $60 \mathrm{~m} / \mathrm{min}$ & Paralela ao perfil \\
\hline Combinação PP85 & $85 \mathrm{~m} / \mathrm{min}$ & Paralela ao perfil \\
\hline Combinação ZZ85 & $85 \mathrm{~m} / \mathrm{min}$ & Ziguezague \\
\hline Combinação TR85 & $85 \mathrm{~m} / \mathrm{min}$ & Trocoidal \\
\hline Combinação TR60 & $60 \mathrm{~m} / \mathrm{min}$ & Trocoidal \\
\hline
\end{tabular}

A usinagem foi feita em desbaste e acabamento. Os $0,7 \mathrm{~mm}$ de profundidade de corte $\left(a_{p}\right)$ a ser usinada nos corpos de prova foi subdividida em $0,5 \mathrm{~mm}$ no desbaste e $0,2 \mathrm{~mm}$ para acabamento, onde foram aplicadas as combinações descritas acima.

A avaliação da qualidade da superfície foi feita por meio da medição dos parâmetros da textura da superfície e parâmetro estatístico, especificamente os parâmetros $R_{a}$ e $R_{t}$, bem como o parâmetro $R_{s k}$ como parâmetro estatístico. Foram feitas quatro medições paralelas ao eixo $x$, mais quatro medições paralelas ao eixo $y$, e também três medidas de rugosidade a $45^{\circ}$ do eixo $x$, totalizando 11 medidas por cavidade, como mostrado na Figura 28.

Figura 28 - Regiões de medição da rugosidade no corpo de prova.

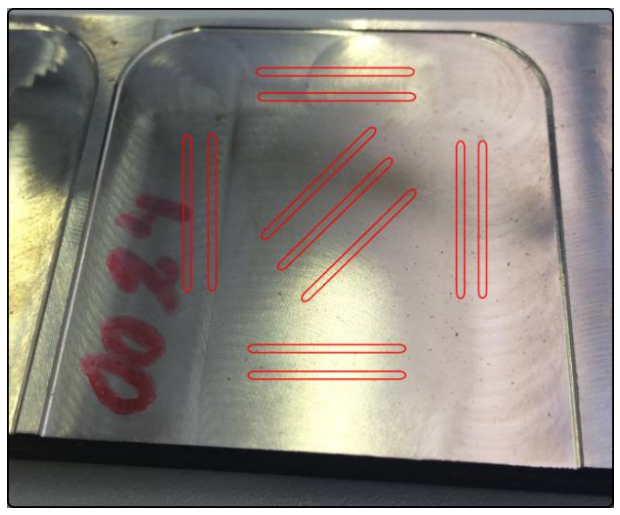

Após obterem-se os resultados, calculou-se o desvio padrão das rugosidades para cada combinação e determinou-se a variância das medições. Buscou-se realizar correlações dos parâmetros de entrada com as rugosidades obtidas, além de relacionar o resultado com a taxa de remo- 
ção e o desgaste da ferramenta. Então foi verificado se os resultados do acabamento no fresamento alcançaram a qualidade adequada.

\subsection{Condução experimental}

Para cada combinação foi utilizada a mesma ferramenta de corte, a qual realiza o acabamento de quatro cavidades. Para a totalidade do experimento foram utilizados seis pares de insertos na operação de acabamento.

A modelagem dos corpos de prova foi feita no software SolidWorks, que possibilita a inserção do modelo computacional no software CAM. O software SolidCam foi utilizado para a geração das estratégias de usinagem e geração dos programas para comando numérico. Foram gerados seis diferentes programas NC correspondentes às seis combinações de parâmetros.

A operação de desbaste foi feita da mesma maneira para todas as cavidades, sendo assim um parâmetro fixo. Já a operação de acabamento foi programada de acordo com as trajetórias selecionadas (ziguezague, paralela ao perfil e trocoidal), mantendo fixos os parâmetros $a_{p}$ e $a_{e}$, mas alterando-se o avanço por dente e a velocidade de corte. O método de entrada da ferramenta na estratégia ziguezague é pela face paralela ao eixo $y$, enquanto nas demais trajetórias o ponto de entrada da ferramenta é em rampa no centro da peça, respeitando-se os parâmetros de inclinação mínima da ferramenta de corte.

As ferramentas de corte foram montadas em cones BT-40 com sistema de pinças, e foi verificado o batimento da ferramenta usando-se um relógio comparador instalado junto ao fuso ("spindle") da máquina.

Para finalizar a preparação do experimento realizou-se o pre-set da máquina mediante a medição das ferramentas de corte e inserção dos dados no CNC, e também definiu-se o ponto zero-peça em relação aos eixos da máquina e, finalmente, carregou-se os programas no CNC da máquina.

\subsection{Procedimentos para avaliação de sustentabilidade do proces- So}

No método aplicado na avaliação dos fatores no processo de usinagem, primeiramente identifica-se os insumos necessários para efetuar a usinagem, os quais são classificados em termos das dimensões social, econômica e ambiental, podendo estar presentes em mais de uma dimensão. 
Depois, deve-se verificar as métricas quanto às grandezas qualitativas e quantitativas. Os indicadores de sustentabilidade podem ser divididos em níveis, os quais podem ser obtidos de diferentes publicações, incluindo-se a diretiva sobre gestão da sustentabilidade descrita pela Associação de Engenheiros Alemães (VDI). É muito importante definir apropriadamente os termos utilizados para a medição de desempenho (Figura 29) [72].

Figura 29 - Níveis de observações necessárias para análise no âmbito do tripé da sustentabilidade, adaptado de [72].

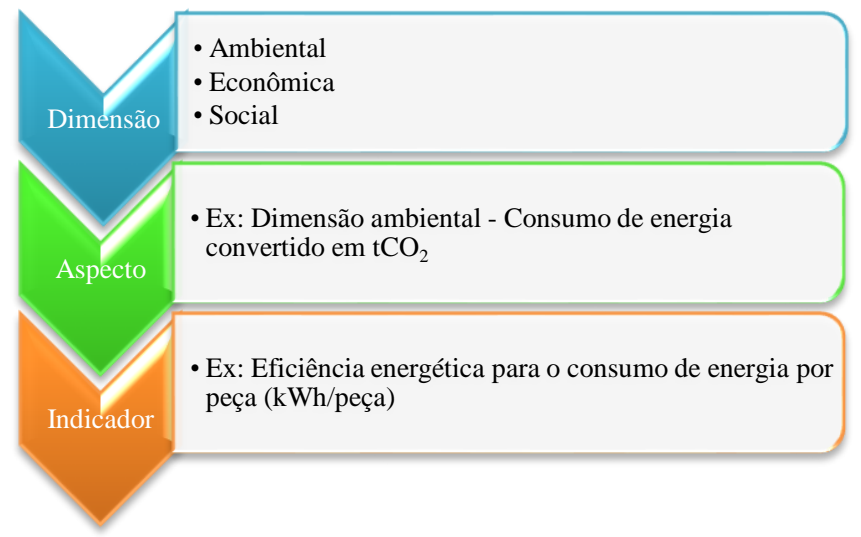

Com o intuito de organizar os dados obtidos foi elaborado um mapa de impactos, análogo ao que se observa em um mapa de riscos, com adaptações contendo os impactos nas dimensões sociais, ambiental e econômica, conforme apresentado na Figura 30.

Após a identificação dos aspectos relacionados à sustentabilidade, é elaborada uma tabela na qual estão contidos os impactos, classificados de acordo com a dimensão. Os aspectos observados neste trabalho são comparados com aqueles encontrados em trabalhos semelhantes anteriores. 
Figura 30 - Modelo para a confecção do mapa de impactos relacionados ao processo de fabricação.

Título do Mapa de Impactos

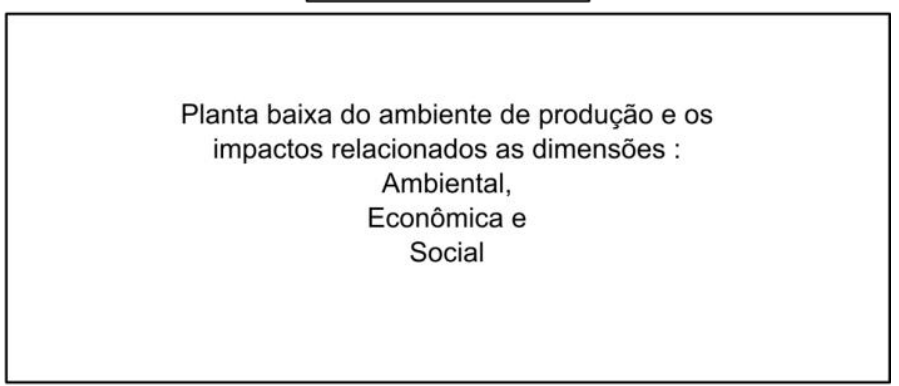

\begin{tabular}{|l|l|}
\hline \multicolumn{1}{|c|}{$\begin{array}{c}\text { Informações do: } \begin{array}{l}\text { Processo } \\
\text { Material } \\
\text { Máquinas }\end{array} \\
\text { Observações }\end{array}$} & Legenda de impactos \\
\hline
\end{tabular}

O método proposto para a avaliação da sustentabilidade nas dimensões do tripé da sustentabilidade possui quatro etapas, mostradas na Figura 31.

Figura 31 - Etapas da metodologia proposta para avaliação do processo de fabricação relacionado ao tripé da sustentabilidade

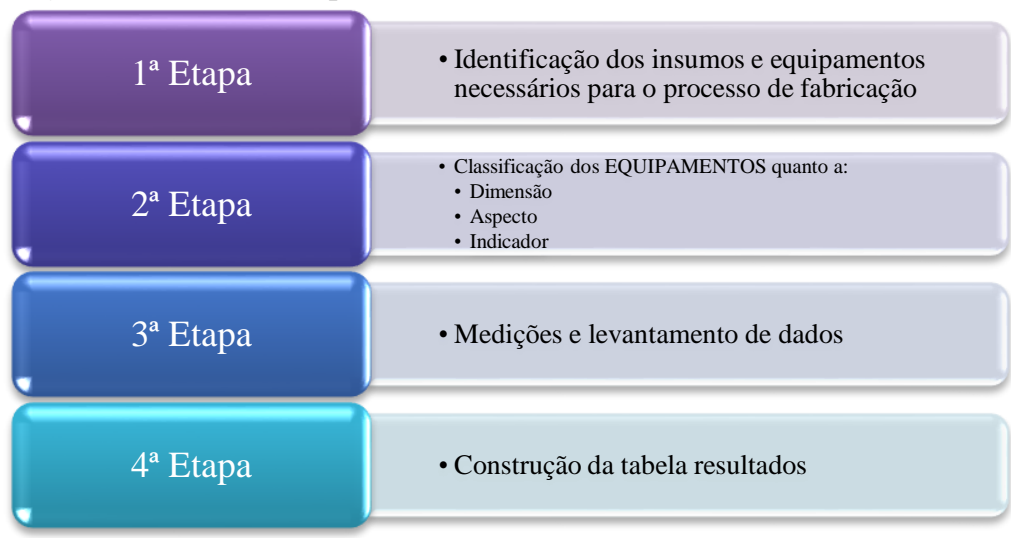

Na primeira etapa é realizada a análise do local onde ocorre o processo de usinagem para identificar todos os elementos de entrada necessários. Na segunda etapa são classificados os equipamentos quanto à dimensão, aspecto e indicador, é necessário diferenciar equipamentos de consumíveis (por exemplo, energia elétrica e ar comprimido), uma 
vez que os consumíveis são identificados na $1^{\mathrm{a}}$ etapa, sendo utilizadas para o funcionamento dos equipamentos.

Para a terceira etapa são aplicados os instrumentos de medição de acordo com os equipamentos identificados nas etapas anteriores, alguns dados podem ser obtidos por intermédio de cálculos ou especificações do equipamento/sistema utilizado, recomendando priorizar a medição dos consumos reais ocorridos na fabricação. Finalizando o método proposto tem-se a quarta etapa, consistindo na construção de uma tabela mostrando os resultados obtidos da análise referente ao tripé da sustentabilidade. 


\section{RESULTADOS E DISCUSSÕES}

Neste capítulo são apresentados os resultados obtidos após a realização dos experimentos descritos no capítulo anterior. Os resultados são divididos em duas partes: (a) resultados da aplicação das combinações de parâmetros de corte e trajetórias descritas no capítulo anterior; (b) resultados da aplicação do método de avaliação sustentável do processo de usinagem como descrito anteriormente.

\subsection{Avaliação da usinagem do aço ferramenta}

\subsubsection{Acabamento da superfície usinada e desgaste de ferramenta}

A operação de fresamento de acabamento é feita visando alcançar uma boa qualidade superficial nas matrizes de trabalho a frio. Essa remoção ocorre com menores volumes de material em comparação com o processo de desbaste, acarretando em menores esforços sofridos pela ferramenta.

Antes de iniciar os testes de usinagem fez-se uma avaliação dos gumes, uma vez que o controle de qualidade do fabricante de ferramentas não é $100 \%$. Foi realizada a microscopia dos gumes, verificando-se que todos os gumes estavam íntegros ao início dos testes, sendo um deles mostrado na Figura 32.

Para as combinações foram utilizados dois gumes para a realização da usinagem de quatro corpos de prova e, ao fim, verificou-se por microscopia o estado dos gumes.

Figura 32 - Microscopia do gume lado "80" inserto número 10.

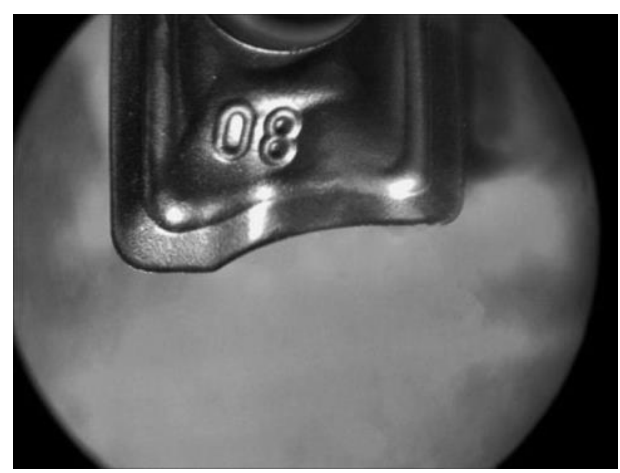


Para cada combinação inicialmente definida foi realizada a usinagem de quatro cavidades para acompanhar a evolução do acabamento superficial ao decorrer da usinagem. Na combinação ZZ60, a Figura 33 apresenta a média das 11 medições de rugosidade na superfície em cada corpo de prova confeccionado.

Figura 33 - Evolução do parâmetro de rugosidade $R_{a}$ e $R_{t}$ para a combinação ZZ60.

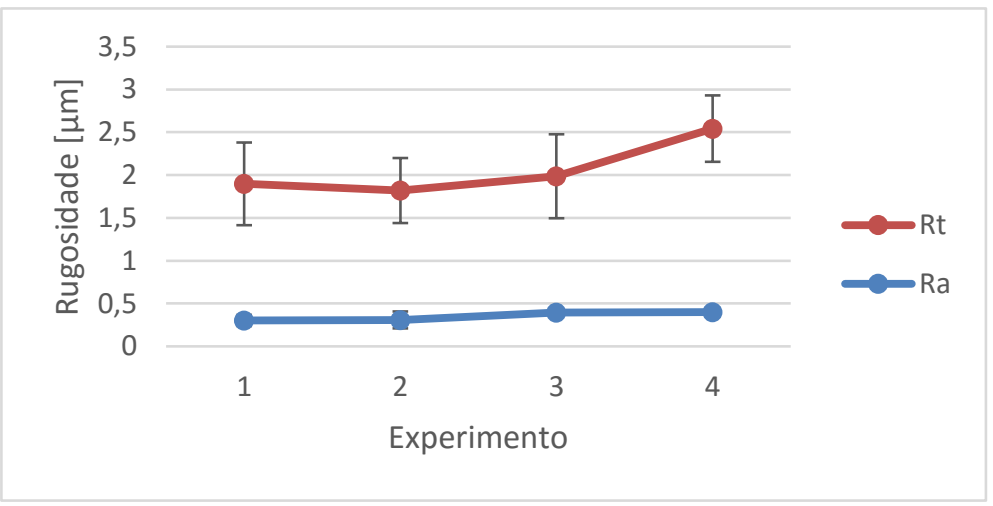

Para a combinação ZZ60 houve um aumento da rugosidade no transcorrer da usinagem, que é causado pela condição final do gume da ferramenta, que apresentou lascamento total em um dos insertos e parcial no segundo inserto (Figura 34). Este tipo de desgaste é comum na usinagem de materiais endurecidos.

Uma observação importante quanto ao lascamento da ferramenta é o ponto de entrada no material, que foi em rampa, respeitado o ângulo máximo de $5^{\circ}$ especificado pelo fabricante, e no início da usinagem houve o corte com profundidade radial máxima. Assume-se que o final da vida dos insertos 1 e 2 deu-se devido ao lascamento do gume. 
Figura 34 - Insertos empregados na velocidade de corte de $60 \mathrm{~m} / \mathrm{min}$ e avanço de $0,07 \mathrm{~mm}$ por dente ao final de quatro experimentos, mostrando o lascamento no gume principal.

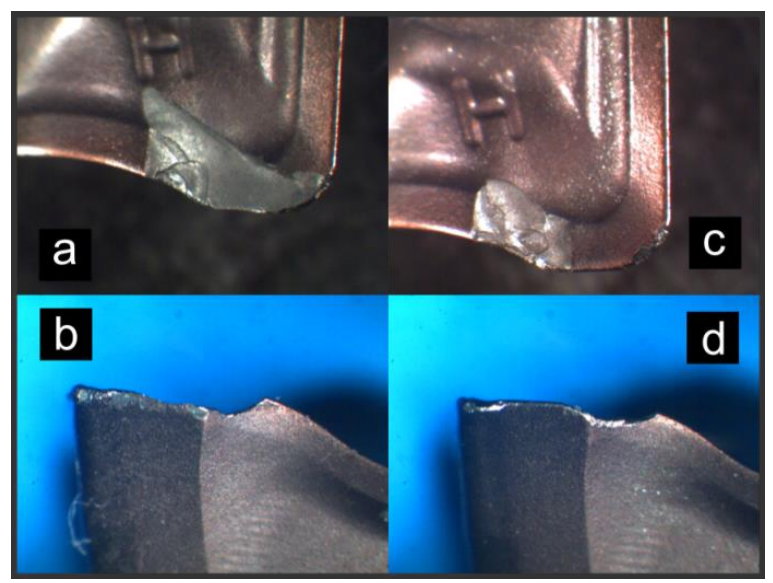

Nas combinações PP60, PP85 e ZZ85, cujo comportamento da rugosidade é apresentado respectivamente nas figuras 35,36 e 37 , o comportamento da média das rugosidades nos dois parâmetros medidos apresenta-se com um perfil semelhante, em que nos dois primeiros experimentos em cada combinação o valor da rugosidade aumenta com o aumento do tempo de uso do gume. Este perfil obtido na qualidade relaciona-se à condição do gume em que nos dois primeiros experimentos ele começa a sofrer com o desgaste pelo uso e, no momento em que estabiliza a afiação do gume, ele tem uma melhora no desempenho de corte ocasionando os menores valores de rugosidade. Passado o período em que o gume ultrapassa a condição estável, volta a aumentar o desgaste, consequentemente aumentando os valores de rugosidade do corpo de prova.

Em alguns experimentos das combinações relatadas anteriormente, é observada a discrepância dos afastamentos da média dos valores de rugosidade no parâmetro $R_{t}$ mostrando em alguns pontos a influência do processo com a presença de pico da superfície, porem como os parâmetros de rugosidade média $R_{a}$ se mantem constante ao decorrer dos experimentos com pouco incremento de valores indica a ocorrência de poucas picos ao longo do comprimento de medição. 
Figura 35 - Evolução dos valores de rugosidade $R_{a}$ e $R_{t}$ para combinação PP60.

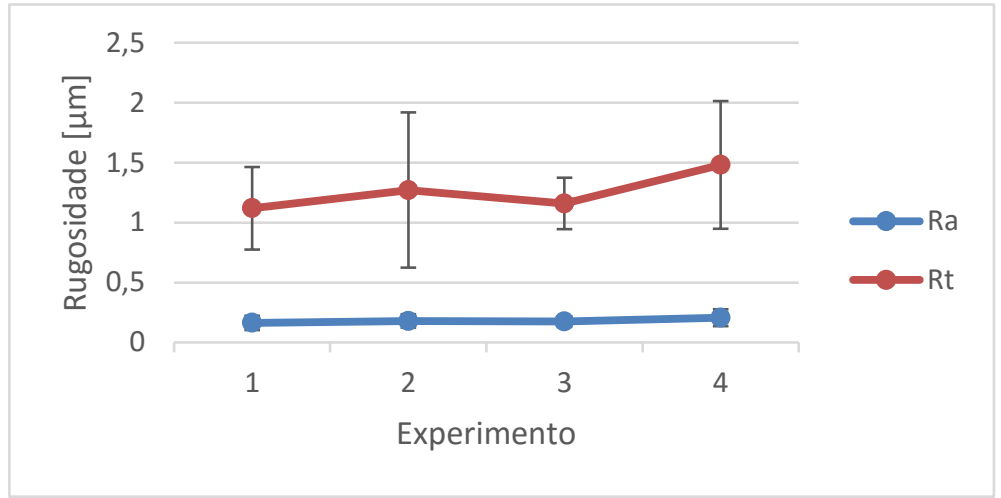

Figura 36 - Evolução dos parâmetros de rugosidade $R_{a}$ e $R_{t}$ medidos na combinação PP85.

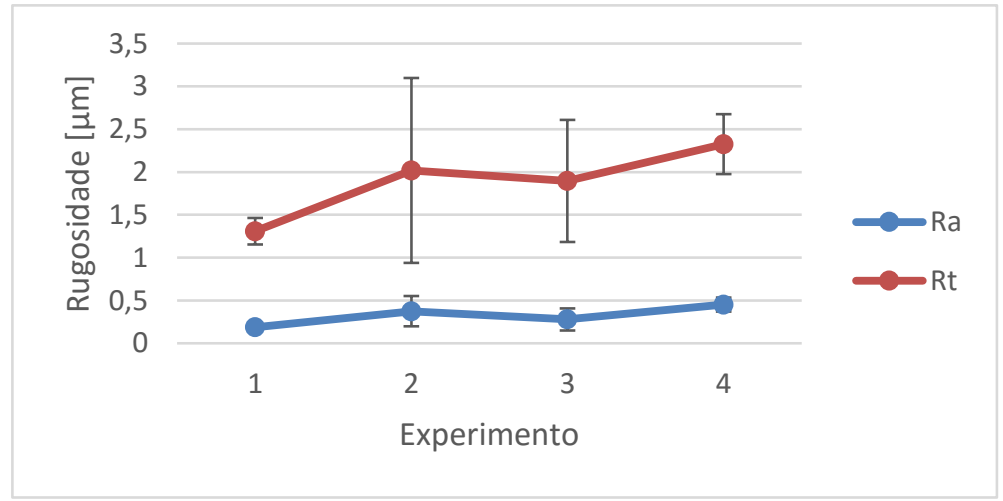


Figura 37 - Evolução dos parâmetros de rugosidade $R_{a}$ e $R_{t}$ medidos na combinação ZZ85.

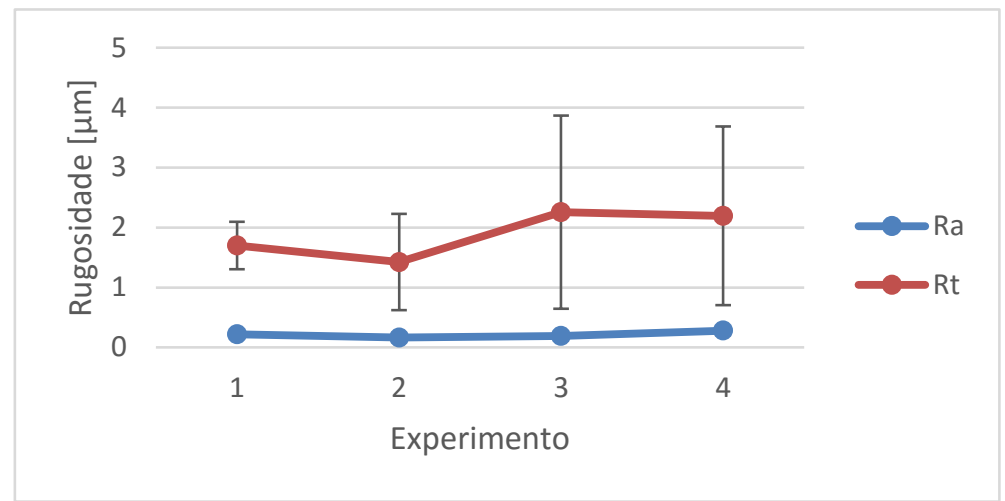

Com o aumento do comprimento de usinagem o gume vai sofrendo desgaste e esse influencia diretamente da interferência entre ferramenta e peça para a remoção do material, o aumento da temperatura e ação do atrito tanto ferramenta/peça e ferramenta/cavaco, diminuem o desempenho do gume, consequentemente, ditando a qualidade da superfície usinada.

Kratochvil [76] apresenta resultados do acabamento superficial em relação ao comprimento de usinagem no fresamento de eletrodos de grafita, onde observa-se uma faixa onde o gume entra na sua faixa de estabilidade e, após a mesma, a qualidade superfície usinada começa a ter aumento de valores mais expressivos.

A estabilização do gume pode ou não ser observada no decorrer da usinagem, sendo esse fenômeno atrelado a vários fatores como as condições de corte, material a ser usinado, geometria da ferramenta de corte; podendo ser monitorado e identificado por meio do acompanhamento dos parâmetros de força de corte ou desgaste do gume pelo comprimento de usinagem. 
O desgaste sofrido pela ferramenta na combinação PP60 (Figura 38) foi de pequena magnitude com $\mathrm{VB}_{\max }$ (desgaste máximo de flanco) $0,160 \mathrm{~mm}$ no inserto 4 e $\mathrm{VB}_{\max }$ no inserto 3 iguais a $0,147 \mathrm{~mm}$.

Figura 38 - Desgaste ferramenta de corte, insertos 3 e 4 ( $\left.\mathrm{VB}_{\max }\right)$.

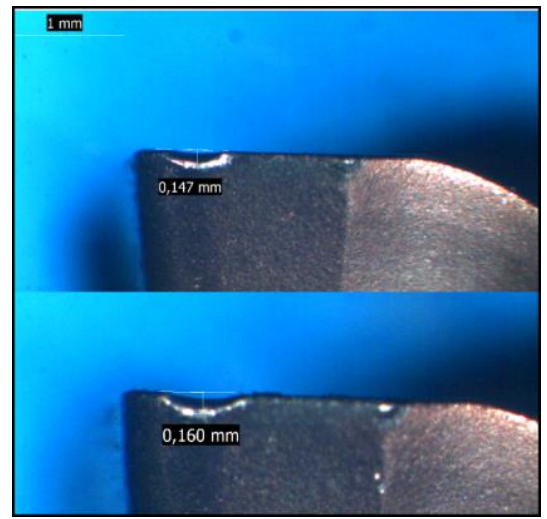

Na combinação PP85 os degastes máximo de flanco foram de $0,390 \mathrm{~mm}$ e $0,374 \mathrm{~mm}$ para os insertos 5 e 6 respectivamente, como mostra a Figura 39a e 39b. A combinação ZZ85 obteve ao final dos experimentos $\mathrm{VB}_{\max }$ de $0,214 \mathrm{~mm}$ no inserto 7 e $0,206 \mathrm{~mm}$ no inserto 8 (Figura 39c e 39d).

Figura 39 - Desgaste dos insertos 5 e 6 (a, b) e insertos 7 e 8 (c,d).

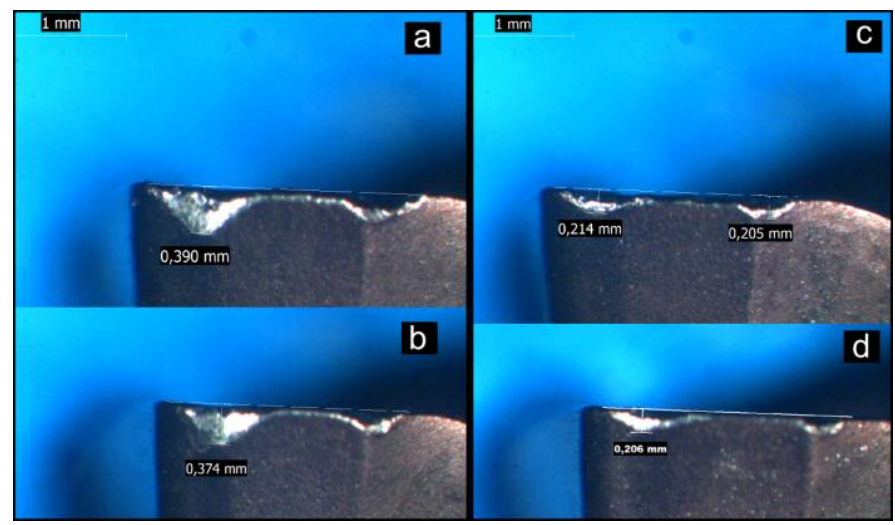


Nas duas últimas combinações testadas (TR85 e TR60) foi empregada à trajetória trocoidal, os resultados obtidos na evolução dos parâmetros de rugosidade foram interessantes, uma vez que não ocorreu um aumento da rugosidade, corroborando a teoria descrita na literatura aonde a trajetória trocoidal conduz a uma maior proteção da ferramenta de corte.

A combinação TR85 tem uma redução em ambos os valores de rugosidade do primeiro para o segundo experimento, no segundo, terceiro e quarto experimentos mantendo-se constante o parâmetro $R_{a}$, e nos dois últimos experimentos a rugosidade $R_{t}$ manteve-se constante (Figura 40).

Figura 40 - Rugosidades $R_{a}$ e $R_{t}$ para combinação TR85.

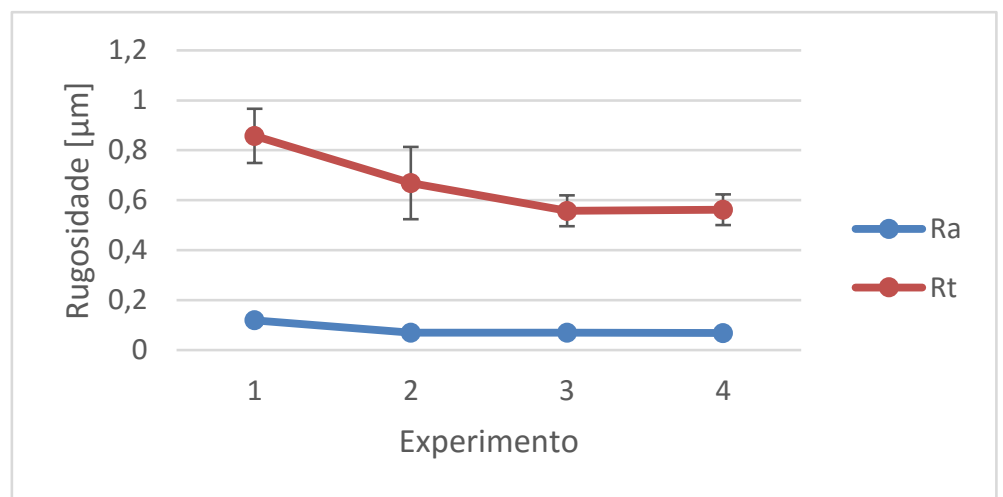

O desgaste máximo de flanco sofrido pela ferramenta da combinação TR85 é apresentado na Figura 41, com valores de 0,101 mm e 0,117 mm para dois dos insertos, estes sendo os desgastes de menor magnitude se comparados com as demais trajetórias e velocidades de corte relatadas anteriormente.

Figura 41 - Desgaste dos insertos 9 e 10.

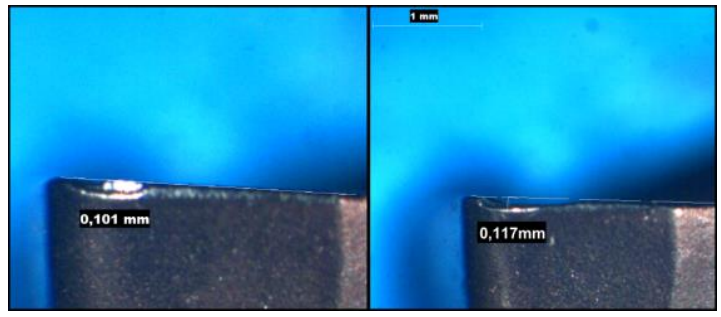


Os resultados de rugosidade obtidos na combinação TR60 são pouco superiores em valor dos encontrados na combinação TR85, mostrando a influência da variação da velocidade de corte, que nessa combinação foi utilizada uma menor velocidade de corte. Klocke [16] relata a correlação entre velocidade e o parâmetro de rugosidade $R_{z}$, apresentado na Figura 42, onde o autor cita que a combinação da baixa velocidade de corte e dependência de material/ferramenta ocorrem à criação de gume postiço, é de extrema necessidade se trabalhar fora dessa faixa de velocidade que apresentam a ocorrência do gume postiço para que se tenha uma boa qualidade da superfície usinada.

Figura 42 - Relação da velocidade de corte com parâmetro de rugosidade $R_{z}$ para corte com $a_{p}=3 \mathrm{~mm}$ e $f=0,25 \mathrm{~mm} / \mathrm{rot}$

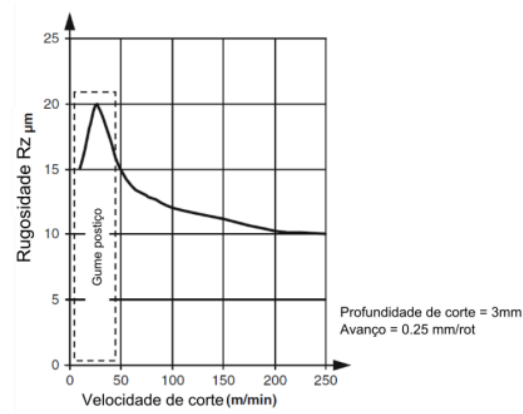

Petropoulos; Pandazaras; Davim [46] também citam a influência da velocidade de corte em relação à rugosidade onde tem-se o aumento da rugosidade com a diminuição da velocidade de corte. Essa influência é mostrada na Figura 43. 
Figura 43 - Perfil de rugosidade da superfície usinada para $f=0,1 \mathrm{~mm} / \mathrm{rot}$ e $a_{p}=0,5 \mathrm{~mm}$ : (a) $\mathrm{v}_{\mathrm{c}}=283 \mathrm{~m} / \mathrm{min}$; (b) $\mathrm{v}_{\mathrm{c}}=141 \mathrm{~m} / \mathrm{min}$; e (c) $\mathrm{v}_{\mathrm{c}}=71 \mathrm{~m} / \mathrm{min}$. Fonte:[46]

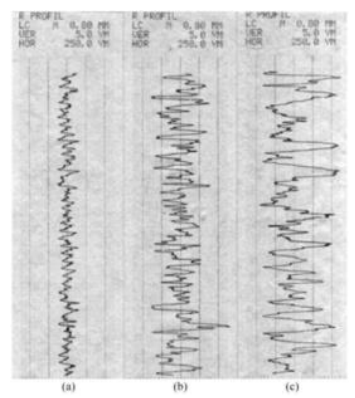

Comparativamente o parâmetro $R_{a}$ na combinação TR60 ficou em média entre $0,15 \mu \mathrm{m}$ e $0,19 \mu \mathrm{m}$ (Figura 44), enquanto que na combinação TR85 os valores ficaram abaixo dos $0,119 \mu \mathrm{m}$ nos quatro experimentos, corroborando a influência da velocidade de corte no processo de usinagem citada anteriormente. Os desgastes máximos dos insertos para a combinação TR60 estão apresentados na Figura 45, importante ressaltar que os desgaste com menor velocidade de corte para a trajetória trocoidal foram de valor muito próximos se comparado com a combinação em que a trajetória trocoidal foi utilizada juntamente com a velocidade de corte de $85 \mathrm{~m} / \mathrm{min}$.

Figura 44 - Evolução dos parâmetros de rugosidade na combinação TR60.

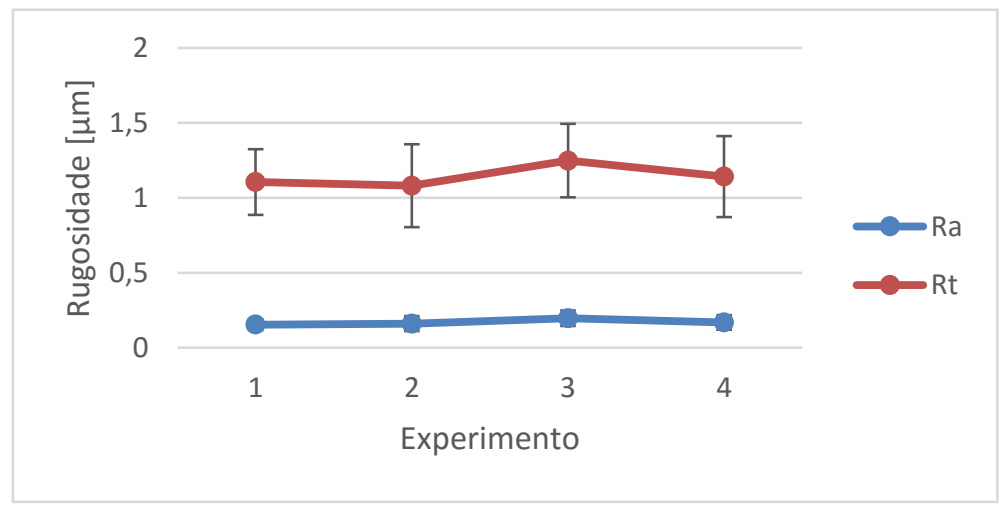


Figura 45 - Desgaste nos insertos 11 e 12 referentes a usinagem da combinação TR60.

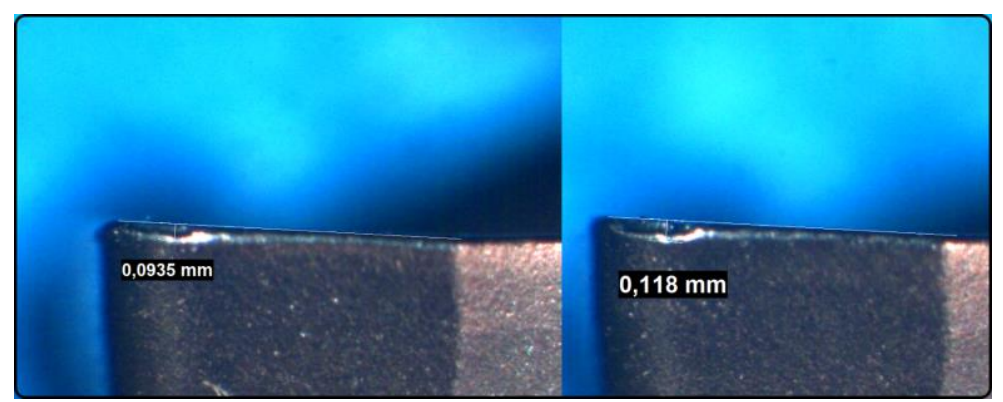

Grzesik [24] apresenta a deterioração do parâmetro de $R_{a}$ ao longo dos experimentos de usinagem devido ao desgaste natural da ferramenta (Figura 46). Ele aponta também que, com a redução dos parâmetros de corte em aproximadamente $10 \%$, obtém-se $R_{a}$ igual a $0,25 \mu \mathrm{m}$ e $R_{t}$ de $1,8 \mu \mathrm{m}$, registrando o desgaste do gume em $0,1 \mathrm{~mm} \mathrm{VB}$ max $\operatorname{nos} 15$ minutos iniciais.

Figura 46 - Relação do tempo de corte e a rugosidade Ra para duas ferramentas e condições diferentes [24].

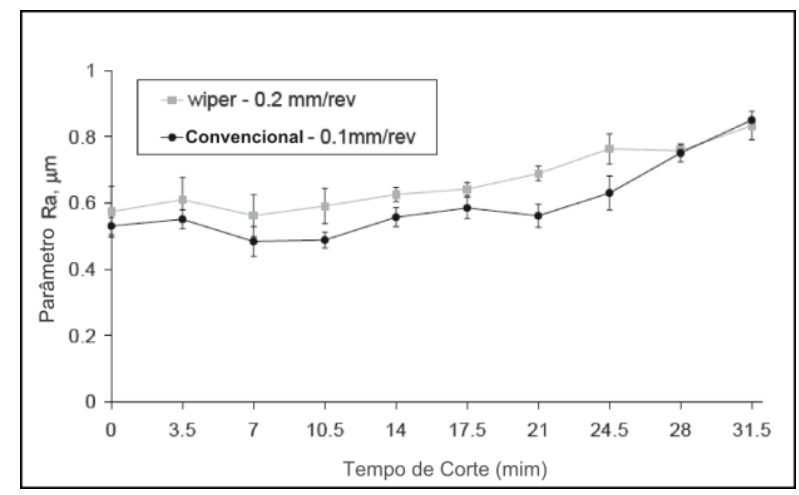

Cavaler [67] abordou em sua pesquisa a busca pela melhor ferramenta para a usinagem do aço SAE D6, realizando uma análise comparativa entre ferramentas de diâmetros diferentes e com cortes diferentes. $\mathrm{O}$ autor utilizou o fresamento periférico na usinagem de insertos para a indústria cerâmica.

No fresamento periférico do aço SAE D6, Cavaler [67] observou principalmente o lascamento do gume como o encontrado na combinação ZZ60 citada anteriormente. Os resultados obtidos por Cavaler 
referentes ao parâmetro de rugosidade $R_{a}$ na usinagem dos insertos para matrizes de compactação de pó cerâmico compreende uma faixa de 0,92 $\mu \mathrm{m}$ a $1,17 \mu \mathrm{m}$, muito acima dos valores obtidos no fresamento frontal desenvolvido nesta pesquisa, porem no desenvolvimento da usinagem Cavaler trabalhou em regime de desbaste. Na Tabela 5 é apresentada uma comparação entre a combinação TR60 (trajetória trocoidal e velocidade de corte de $60 \mathrm{~m} / \mathrm{mim}$ ) e o fresamento periférico de Cavaler [67].

Tabela 5 - Comparativo de parâmetros de rugosidade $R_{a}$.

\begin{tabular}{|l|c|c|}
\hline & Trabalho atual & Cavaler [67] \\
\hline Rugosidade Ra $(\boldsymbol{\mu m})$ & \multirow{2}{*}{0,19 (maior valor obtido) } & 0,92 (sentido longitudinal) \\
\cline { 3 - 3 } & & 1,17 (sentido transversal) \\
\hline
\end{tabular}

Comparando-se com os valores para o parâmetro $R_{a}$ obtidos pelo processo de fresamento no trabalho de Grzesik; Kruszynski; Ruszaj [47], pode-se afirmar que os valores da rugosidade obtidos neste trabalho encontram-se em uma faixa de aplicação menos comum como mostra a Figura 47, que é na direção de uma superfície de menor rugosidade. A faixa de aplicação menos comum situa-se entre $1,6 \mu \mathrm{m}$ e $0,2 \mu \mathrm{m}$, como pode ser observado no capítulo 2 , na figura 14 . Como o maior valor obtido nos testes realizados foi de $0,4 \mu \mathrm{m}$, considera-se este um valor adequado de rugosidade.

Figura 47 - Faixas de rugosidade $R_{a}$ para o processo de fabricação por fresamento. Fonte: adaptado de [47]

Rugosidade média $R_{\mathrm{a}} \mu \mathrm{m}$

Processo

Fresamento

$\begin{array}{lllllllllllll}50 & 25 & 12.5 & 6.3 & 3.2 & 1.6 & 0.80 & 0.40 & 0.20 & 0.10 & 0.05 & 0.025 & 0.012\end{array}$

O parâmetro de rugosidade $R_{s k}$ (fator de assimetria) medido nas superfícies usinadas têm seus valores das médias para cada combinação mostrada na Tabela 6.

Tabela 6 - Média de valores do parâmetro $R_{s k}$ medidos para cada combinação.

\begin{tabular}{|cc|}
\hline & $\boldsymbol{R}_{\text {sk }}$ \\
\hline Combinação ZZ60 & 0,077 \\
\hline Combinação PP60 & 0,372 \\
\hline Combinação PP85 & 0,032 \\
\hline Combinação ZZ85 & 0,699 \\
\hline Combinação TR85 & 0,092 \\
\hline Combinação TR60 & 0,068 \\
\hline
\end{tabular}


A importância deste parâmetro de assimetria está na identificação das superfícies usinadas de acordo com a sua aplicação de engenharia. Em aplicações de fabricação de moldes e matrizes são desejáveis superfícies usinadas por processos convencionais que apresentem um fator de assimetria maior ou igual à zero, uma vez que após a usinagem estão aplicados processos de usinagem fina onde as taxas de remoção de material são baixas e pode ser mais trabalhoso com uma superfície de $R_{s k}$ negativo se comparado a uma onde o fator de assimetria é positivo. Porem em algumas aplicações se faz necessária uma maior superfície de suporte, interessante que o processo de usinagem gere superfície com assimetria negativa.

Para avaliar os degastes do gume da ferramenta de corte, será adotado o $\mathrm{VB}_{\max }$ descrito na norma ISO 3685, a qual estabelece ensaios de usinabilidade para determinar o momento de troca ou reafiação da ferramenta em trabalho como relatado por Amorim [77]. $\mathrm{O}$ valor de $\mathrm{VB}_{\max }$ para avaliar os resultados da pesquisa é de $0,3 \mathrm{~mm}$ ou falha catastrófica da ferramenta. Na Tabela 7 estão compilados os resultados das ferramentas em comparação com os critérios adotados.

Tabela 7 - Resultados referentes ao desgaste dos insertos para diferentes combinações.

\begin{tabular}{|cc|cc|}
\hline $\begin{array}{c}\text { Combinação } \\
\text { ZZ60 }\end{array}$ & Falha gume & Falha gume & Nañão conforme \\
\hline $\begin{array}{c}\text { Combinaçã } \\
\text { PP60 }\end{array}$ & $0,147 \mathrm{~mm}$ & $0,160 \mathrm{~mm}$ & Conforme \\
\hline $\begin{array}{c}\text { Combinação } \\
\text { PP85 }\end{array}$ & $0,390 \mathrm{~mm}$ & $0,347 \mathrm{~mm}$ & Não conforme \\
\hline $\begin{array}{c}\text { Combinação } \\
\text { ZZ85 }\end{array}$ & $0,214 \mathrm{~mm}$ & $0,206 \mathrm{~mm}$ & Conforme \\
\hline $\begin{array}{c}\text { Combinação } \\
\text { TR85 }\end{array}$ & $0,101 \mathrm{~mm}$ & $0,117 \mathrm{~mm}$ & Conforme \\
\hline $\begin{array}{c}\text { Combinação } \\
\text { TR60 }\end{array}$ & $0,093 \mathrm{~mm}$ & $0,118 \mathrm{~mm}$ & Conforme \\
\hline
\end{tabular}

Necessário ressaltar que na usinagem dura, pequenas alterações na geometria da ferramenta, principalmente no raio do gume, alteram o comportamento do processo de corte traduzindo-se no fim de tempo de vida. Deve ser analisado para cada caso qual o desgaste admissível na relação ferramenta/material bruto, para que não se tenha a probabilidade de quebra da ferramenta (inserto) e inutilização de outros gumes presentes no inserto. 


\subsubsection{Energia ativa despendida na remoção de material}

Um fator importante na avaliação da usinagem é a utilização dos insumos de maneira eficiente, visto que o bom uso de recursos tem reflexo em todo o processo produtivo abrangendo as áreas de custos, qualidade e responsabilidade ambiental. A quantificação da energia ativa durante a usinagem foi possibilitada por meio da utilização do transdutor, descrito no capítulo de Materiais e Métodos. As informações coletadas durante a operação foram armazenadas em formato de um relatório gerado pelo próprio software do equipamento.

Os resultados referentes à energia ativa foram determinados uma vez que esta energia é a responsável pela realização das movimentações. A componente ativa é medida em Wh (watts-hora), e é a componente da energia elétrica transformada em outras formas de energia [78]. No contexto da máquina-ferramenta uma parcela da energia é convertida em energia cinética e outra destinada a componentes eletroeletrônicos para comando e controle de posicionamentos e acionamentos.

Na Figura 48 são mostradas as médias de consumo de energia ativa para as combinações para obter a forma final dos corpos de prova. Os consumos relacionam-se ao tempo de ciclo e ao processamento total, sendo utilizados os parâmetros de profundidade $a_{p}, a_{e}$ e avanço por dente $f_{z}$ constantes. O aumento da velocidade de corte resulta em um maior consumo de energia devido à exigência de uma maior rotação do eixo árvore.

Figura 48 - Energia ativa consumida durante a usinagem dos corpos de prova.

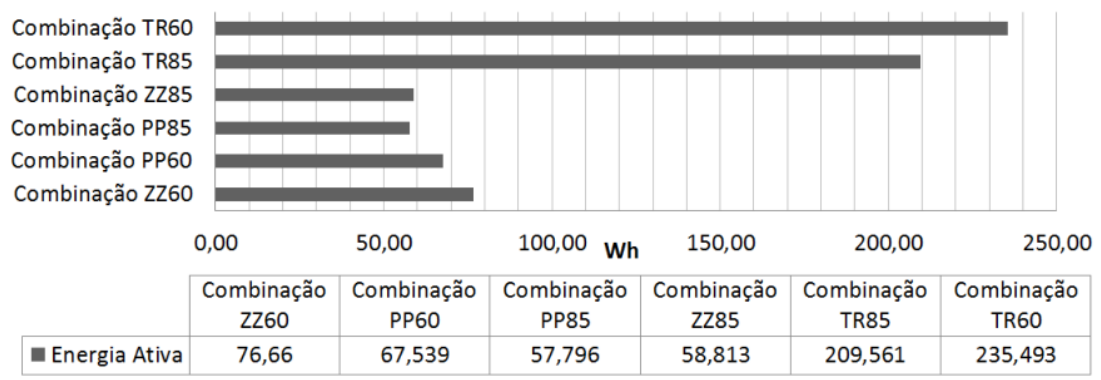

Como citado anteriormente o tempo de ciclo para as seis combinações tem uma relativa diferença entre as trajetórias e com menor variação para a mesma trajetória porem com a variação da velocidade de corte. Os tempos de ciclo são mostrados na Tabela 8. 
Tabela 8 - Tempos de ciclo para as diferentes trajetórias.

\begin{tabular}{|lc|}
\hline Combinação & Tempo de ciclo \\
\hline Combinação ZZ60 & $4 \mathrm{mim} 34 \mathrm{~s}$ \\
\hline Combinação PP60 & $4 \mathrm{mim} 37 \mathrm{~s}$ \\
\hline Combinação PP85 & $3 \mathrm{mim} 36 \mathrm{~s}$ \\
\hline Combinação ZZ85 & $3 \mathrm{mim} 24 \mathrm{~s}$ \\
\hline Combinação TR85 & $14 \mathrm{mim} 57 \mathrm{~s}$ \\
\hline Combinação TR60 & $14 \mathrm{mim} 55 \mathrm{~s}$ \\
\hline
\end{tabular}

\subsection{Avaliação sustentável nas dimensões ambiental, econômica e social}

Os procedimentos para avaliação da sustentabilidade foram aplicados ao ambiente do laboratório de usinagem $\mathrm{CNC}$ do Colégio Técnico Industrial de Santa Maria, RS. As ocorrências no ambiente de ensino não refletem inteiramente a realidade do chão de fábrica convencional, porém essa avaliação foi idealizada de maneira a poder ser aplicada em ambiente de fabricação, desde que se possa identificar e medir as variáveis envolvidas no processo.

\subsubsection{Identificação dos insumos para usinagem}

Como definido na norma ABNT NBR 6175 [17], no processo de fresamento utiliza-se uma ferramenta multicortante que gira em torno de seu próprio eixo enquanto a peça se movimenta em relação à ferramenta segundo uma determinada trajetória. Os insumos presentes no processo de usinagem são importantes para a sustentabilidade já que, para transformar o material bruto em produto final, há a necessidade de consumo de energia, além de serem gerados resíduos.

Abaixo estão expostos os insumos que fazem parte do processo de usinagem e são importantes para a avaliação da sustentabilidade do processo de fabricação:

- Máquina ferramenta;

- Matéria-prima (Material bruto);

- Ferramenta de usinagem;

- Suporte de ferramenta e fixações da peça;

- Energia elétrica;

- Compressor de ar;

- Ar comprimido; 
- Óleo lubrificante;

- Infraestrutura predial (iluminação, janelas, ar condicionado, isolamento térmico e solar);

$\mathrm{Na}$ exposição dos resultados e classificação foram adotados os equipamentos como entrada, e a cada um deles relacionou-se o consumo de energia ou geração de resíduos. Na avaliação a correta observação e monitoramento do que ocorre nos insumos é importante uma vez que eles estão relacionados a mais de um âmbito da sustentabilidade estuda neste trabalho. Tem o exemplo da máquina ferramenta que tem muitos aspectos inter-relacionados nas três dimensões da sustentabilidade (ambiental, econômica e social).

\subsubsection{Classificação das observâncias referentes à dimensão ambiental}

Após a identificação dos insumos contidos no ambiente de usinagem pode-se classificá-los quanto à dimensão de sustentabilidade. Outra tarefa realizada consiste em descrever os indicadores relacionados à dimensão, de maneira a possibilitar a medição ao longo da usinagem e a padronização da métrica de análise, visando comparar os valores obtidos.

Na Tabela 9 são mostradas as entradas do processo de usinagem, os aspectos relacionados à dimensão ambiental, e os respectivos indicadores.

Tabela 9 - Classificação das entradas do processo para o aspecto ambiental.

\begin{tabular}{|c|c|c|}
\hline Entrada & Aspecto ambiental & Indicador \\
\hline \multirow{3}{*}{ Máquina-ferramenta } & Consumo de energia convertido em emissão de $\mathrm{CO}_{2}$ & $\mathrm{tCO}_{2}$ na atm. \\
\hline & Utilização de fluido lubrirrefrigerante & Sim ou Não \\
\hline & Consumo de óleo lubrificante & Litros/mim \\
\hline Matéria prima & Resíduo sólido & $\mathrm{Kg}$ \\
\hline $\begin{array}{c}\text { Ferramenta de usina- } \\
\text { gem }\end{array}$ & Resíduo sólido & $\mathrm{Kg}$ \\
\hline Compressor de ar & $\begin{array}{l}\text { Consumo de energia elétrica convertido em emissão } \\
\qquad \text { de } \mathrm{CO}_{2}\end{array}$ & $\mathrm{tCO}_{2}$ na atm \\
\hline \multirow[t]{2}{*}{ Infraestrutura predial } & $\begin{array}{l}\text { Consumo de energia elétrica convertido em emissão } \\
\text { de } \mathrm{CO}_{2}\end{array}$ & $\begin{array}{c}\mathrm{Kg} / \mathrm{cm}^{3} \text { de } \mathrm{CO}_{2} \text { na } \\
\text { atm }\end{array}$ \\
\hline & Resíduo sólido & $\mathrm{Kg}$ \\
\hline
\end{tabular}

4.2.3 Classificação da dimensão social

A indústria, em particular o setor da manufatura, enfrenta desafios quanto ao contexto de turbulência socioeconômica devido à complexidade dos processos e as mudanças nesse ambiente [79]. O mesmo autor ainda cita que os avanços na indústria precisam considerar os aspectos humanos, apontando para o conceito de "sistema de automação 
equilibrado". Nesse contexto, o processo de fresamento com centro de usinagem CNC depende da atuação de um operador. Apesar da possibilidade de se acrescentar alguma inteligência ao sistema de usinagem, é necessária a presença de um operador/programador e, do ponto de vista social, deve-se considerar o aspecto social quanto aos riscos aos qual o ser humano está exposto durante a operação de fabricação.

$\mathrm{Na}$ Tabela 10 são mostradas as entradas do processo de usinagem na dimensão social, bem como os respectivos indicadores.

Tabela 10 - Classificação dos das entradas do processo para o aspecto social.

\begin{tabular}{|ccc|}
\hline \multirow{4}{*}{ Entrada } & Aspecto social & Indicador \\
\cline { 2 - 3 } Máquina-Ferramenta & Exposição à contaminação química & SIM/NÃO \\
\cline { 2 - 3 } & Exposição a ruídos sonoros & dB (decibéis) \\
\cline { 2 - 3 } & Posição do operador durante usinagem & BOM/RUIM \\
\cline { 2 - 3 } & Risco de acidente & SIM/NÃO \\
\hline \multirow{2}{*}{ Matéria prima } & Risco de acidente & SIM/NÃO \\
\hline Ferramenta de usinagem & Risco de contaminação & SIM/NÃO \\
\hline Compressor de ar & Risco de acidente & SIM/NÃO \\
\hline \multirow{3}{*}{ Infraestrutura predial } & Exposição a ruidos sonoros & dB (decibéis) \\
\cline { 2 - 3 } & Climatização & SIM/NÃO \\
\cline { 2 - 3 } & Luminosidade do ambiente & Lux \\
\cline { 2 - 3 } & Limpeza e organização & SIM/NÃO \\
\hline
\end{tabular}

\subsubsection{Classificação da dimensão econômica}

Estimar os custos é uma atividade extremamente importante na manufatura, e esta estimativa começa na concepção do produto a ser fabricado, e depois nas operações presentes no plano de processo de fabricação, e finalmente na execução propriamente dita da fabricação do produto. Na dimensão econômica tem-se a necessidade de quantificar principalmente os custos produtivos decorrentes do uso dos insumos presentes na usinagem.

As entradas do processo de usinagem na dimensão econômica são apresentadas na Tabela 11, a qual também contém o indicador para cada insumo.

Tabela 11 - Classificação dos das entradas do processo para o aspecto econômico.

\begin{tabular}{|ccc|}
\hline Entrada & Aspecto econômico & Indicador \\
\hline \multirow{2}{*}{ Máquina-ferramenta } & Consumo de energia convertido em $\mathrm{R} \$$ & $\mathrm{R} \$ / \mathrm{hora}$ \\
\cline { 2 - 3 } & Consumo de óleo & $\mathrm{R} \$ / \mathrm{hora}$ \\
\hline \multirow{2}{*}{ Material prima } & Custo matéria prima & $\mathrm{R} \$ / \mathrm{kg}$ \\
\cline { 2 - 3 } & Custo com tratamento térmico & $\mathrm{R} \$ / \mathrm{kg}$ \\
\cline { 2 - 3 } & Custo com resíduos sólidos & $\mathrm{R} \$ / \mathrm{kg}$ \\
\hline \multirow{2}{*}{ Ferramenta de usinagem } & Custo do suporte ferramenta & $\mathrm{R} \$$ \\
\cline { 2 - 3 } & Custo com gume & $\mathrm{R} \$ / \mathrm{hora}$ \\
\hline Compressor de ar & Custo de energia convertido em $\mathrm{R} \$$ & $\mathrm{R} \$ / \mathrm{hora}$ \\
\hline Infraestrutura predial & Consumo de energia elétrica & $\mathrm{R} \$ / \mathrm{hora}$ \\
\hline
\end{tabular}


Neste trabalho a avaliação da dimensão econômica está na direção da utilização dos consumíveis, não contemplando os valores de hora máquina ao exemplo de uma ferramentaria, onde no valor cobrado ao cliente estão previstos os desde o custo de aquisição da máquina ferramenta, custos de manutenção preditiva e preventiva, lucro, dentre outros custos envolvidos na fabricação de matrizes e moldes.

O caso específico de aplicar a metodologia em um laboratório voltado para o ensino tecnológico não se tem a informação clara relacionada a custos de aquisição dos equipamentos, porém é possível a aplicação na indústria em geral com a adaptação das métricas em cada dimensão em acordo com as ocorrências e necessidades de avaliação do cenário em estudo.

4.2.5 Resultados referentes às dimensões ambiental, econômica e social

Cumpridas as etapas de organização e observação do local onde são efetuadas as operações de usinagem, realiza-se a usinagem e ao mesmo tempo a coleta de dados.

A quantidade de $\mathrm{CO}_{2}$ emitido foi obtida mediante o cálculo do consumo da energia elétrica dos equipamentos multiplicado ao fator de emissão disponibilizado pelo Ministério da Ciência e Tecnologia [80], índice esse que é atualizado mensalmente com base na matriz de geração da energia elétrica brasileira relacionada ao sistema nacional interligado. Nos anos de 2014 e 2015 o Brasil sofreu com um período de seca, resultando em menores volumes de água para a geração de energia nas hidrelétricas, necessitando-se o acionamento de termoelétricas, emitindo-se maior quantidade gases do efeito estufa. Com o intuito de comparar esses valores, o fator de emissão anual médio do ano de 2011 foi de $0,0292 \mathrm{tCO}_{2} / \mathrm{MWh}$, já o fator anual médio do ano de 2015 foi de 0,1244 $\mathrm{tCO}_{2} / \mathrm{MWh}$.

Os cálculos para os resultados de emissão de $\mathrm{CO}_{2}$ na atmosfera utilizaram o fator de emissão médio anual do ano de 2015, conforme a equação (2).

$E=C_{e} \times F_{e}$

Onde:

$\mathrm{E}=$ emissão $\left(\mathrm{tCO}_{2}\right)$

$\mathrm{C}_{\mathrm{e}}=$ consumo $(\mathrm{Wh})$

$\mathrm{F}_{\mathrm{e}}=$ Fator de emissão $\left(\mathrm{tCO}_{2} / \mathrm{Wh}\right)$ 
Os resultados referentes às emissões na atmosfera para o compressor de ar e infraestrutura predial e utilização de energia pela máquina ferramenta estão expressos na figura 50, para o tempo de uma hora de utilização dos recursos.

O total de emissões ao decorrer do período de uma hora foi de $0,00018 \mathrm{tCO}_{2}$, e na Figura 49 é mostrada a participação dos equipamentos e da infraestrutura em porcentagem do valor total da emissão.

Figura 49 - Emissão de $\mathrm{CO}_{2}$ para o tempo de usinagem de uma hora de utilização de energia.

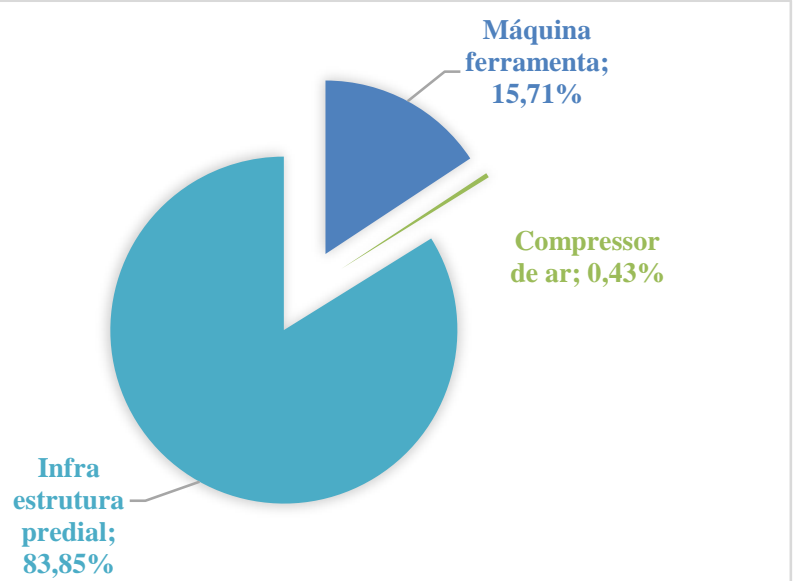

Klocke [16] e Lacalle [37] recomendam que aços endurecidos sejam usinados sem a utilização de fluidos de corte e, portanto, a usinagem desses materiais respeita o meio ambiente. Deve-se mencionar que todos os experimentos realizados neste trabalho a usinagem foram realizados a seco.

No caso da utilização de óleo pela máquina-ferramenta, a lubrificação ocorre de maneira automática, onde a cada seis minutos são injetados 2,5 $\mathrm{ml}$ de óleo ISO VG 68, sendo injetado principalmente nos fusos de esfera responsáveis pelos movimentos da mesa nos eixos $x$ e $y$, ainda lubrificando as guias do eixo $z$. Deve-se ressaltar que esse óleo não entra em contato com o restante da máquina, como os compartimentos de fluidos lubrirrefrigerantes e meios externos.

No âmbito dos aspectos sociais é necessária a avaliação da exposição do operador a risco de acidentes. No ambiente de usinagem CNC os riscos estão ligados às condições e características da máquina utilizada. Nos experimentos realizados, o centro de usinagem conta com 
uma carenagem protetora e uma porta com fechadura elétrica que evita o funcionamento da mesma com porta aberta.

Durante a realização das atividades de preparação do material sobre a mesa, e medição das posições relativas para inserção no comando $\mathrm{CNC}$, a máquina opera com velocidade de deslocamento limitada, aumentando a proteção do operador. Mas é necessário sempre considerar o risco de acidente em qualquer processo produtivo envolvendo máquinas, automação e intervenção humana, no contexto da pesquisa optou-se por considerar positivo o risco de acidente, entretanto a probabilidade da ocorrência é baixa.

A análise ergonômica durante uma tarefa consiste na observação sistemática de pessoas trabalhando, focando no trabalho efetivo desempenhado, observando também as condições de contorno impostas pela tarefa a ser desempenhada [81]. Efetuou-se a análise do ambiente em que o operador está atuando no transcorrer da fabricação das peças.

A questão de ergonomia é regida pela Norma Regulamentadora 17 [82], a qual infere quanto às posições de trabalho, manuseio de material, conforto térmico e acústico, luminosidade. Para avaliar os resultados foram observadas as recomendações da faixa de 20 a $23^{\circ} \mathrm{C}$ de temperatura ambiente, conforto sonoro de no máximo $65 \mathrm{~dB}$, e índice de luminosidade de interior de 300 a 500 Lux conforme a NBR 5413 [83].

A luminosidade disponível no ambiente e o conforto térmico são bons segundo os requisitos da NR-17, a luminosidade medida durante os testes variou entre 316 a 352 lux e a temperatura do ambiente é controlada pelos dois condicionadores de ar regulados na temperatura de $23^{\circ} \mathrm{C}$.

O índice de emissão sonora em média ultrapassou o recomendado de $65 \mathrm{~dB}$ durante a usinagem, alcançando pico de 93,9 dB, valor esse obtido na combinação 1, replicação 4, como mostra a Figura 50, que contém o perfil da emissão acústica captada ao longo da operação, onde o instrumento de medição que captou a emissão acústica estava localizado a $1600 \mathrm{~mm}$ do chão e a uma distância de $500 \mathrm{~mm}$ da porta principal da máquina ferramenta, posição típica do operador durante o transcorrer da tarefa de usinagem. Assim, o impacto negativo para o âmbito social é alto, havendo a necessidade do uso de equipamento de proteção individual (EPI) como protetor auricular ou abafador. 
Figura 50 - Perfil típico da pressão sonora captada durante um ensaio a uma distância de $500 \mathrm{~mm}$ da porta frontal da máquina ferramenta.

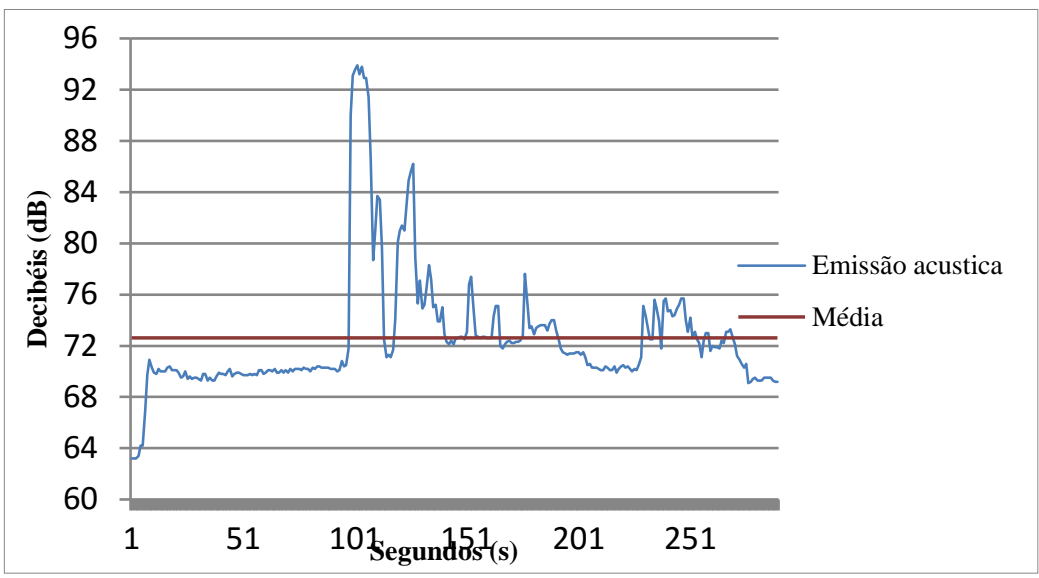

Com relação à preparação da matéria-prima e ferramentas de usinagem no que diz respeito às normas de ergonomia (NR-17), não foram identificados problemas ergonômicos de manuseio dos materiais na usinagem realizada. Deve-se ressaltar que no manuseio de matérias e ferramentas há o risco de acidente, porém tomando-se as devidas precauções esta tarefa é realizada sem problemas. No caso especifico em estudo neste trabalho não apresentou problemas de manuseio, porem em casos de ferramentarias onde moldes e matrizes podem ultrapassar 100 $\mathrm{kg}$ de material bruto a análise do manuseio com os equipamentos adequados, como paleteiras, pontes rolantes ou guinchos, considerando toda a segurança no processo e também dos equipamentos.

Do ponto de vista ambiental, a matéria-prima e as ferramentas de corte apresentaram aspectos positivos como, por exemplo, os materiais são recicláveis e reutilizáveis, não necessitando descarte após o uso. O resíduo gerado pela usinagem (cavacos) é recolhido e entregue para uma empresa especializada na reciclagem de metais. Como foi analisado o processo de acabamento, o volume de cavacos gerado não é elevado, como mostrado na Figura 51. 
Figura 51 - Volume total de cavaco removido.

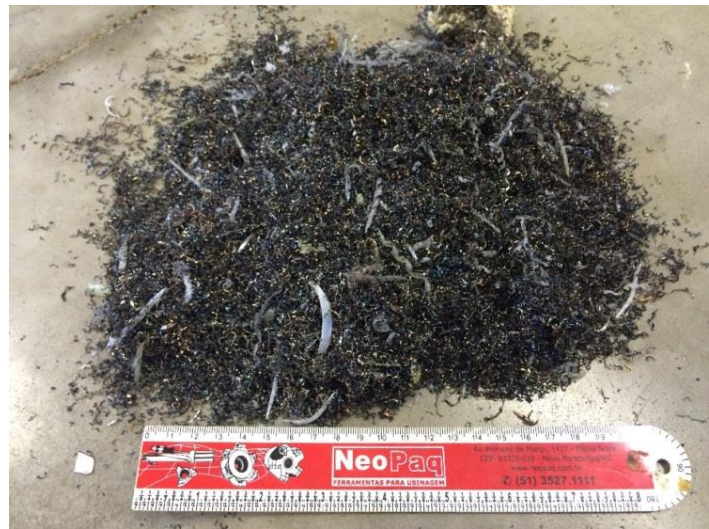

A preocupação sustentável equivale a uma combinação suportável de recursos para realização do processo econômico, a qual pressupõe que os ecossistemas operam dentro de uma amplitude capaz de conciliar condições econômicas e ambientais [84].

Os resultados da análise na dimensão econômica são mostrados na Figura 52. Para isso mediu-se a energia consumida por dispositivos durante a fabricação, quantificando o consumo em Watts hora (Wh) e convertidos para reais $(\mathrm{R} \$)$ considerando-se o custo da energia elétrica igual a $0,208880 \mathrm{R} \$ / \mathrm{kWh}$, que é o custo citado no site da AES Sul, distribuidora de energia da região central do Rio Grande do Sul [85]. Não são incluídos nos cálculos os encargos da fornecedora de energia nem tributos. Os custos com ferramentas e materiais foram obtidos mediante contato com os fornecedores.

O custo em reais foi calculado usando-se a equação (3). Após a realização dos cálculos para obtenção dos custos, os resultados estão mostrados na Figura 52.

$$
C_{\$}=C_{e} \times C_{\$ W h}
$$

Onde:

$\mathrm{C}_{\$}=$ Custo em Reais $[\mathrm{R} \$]$;

$\mathrm{C}_{\mathrm{e}}=$ Consumo energia ativa;

$\mathrm{C}_{\$ \mathrm{Wh}}=$ Custo do Watt-hora $[\mathrm{R} \$ / \mathrm{Wh}]$. 
Figura 52 - Custos relacionados aos consumos energéticos dos equipamentos, infraestrutura e materiais necessários para o processo de fabricação.

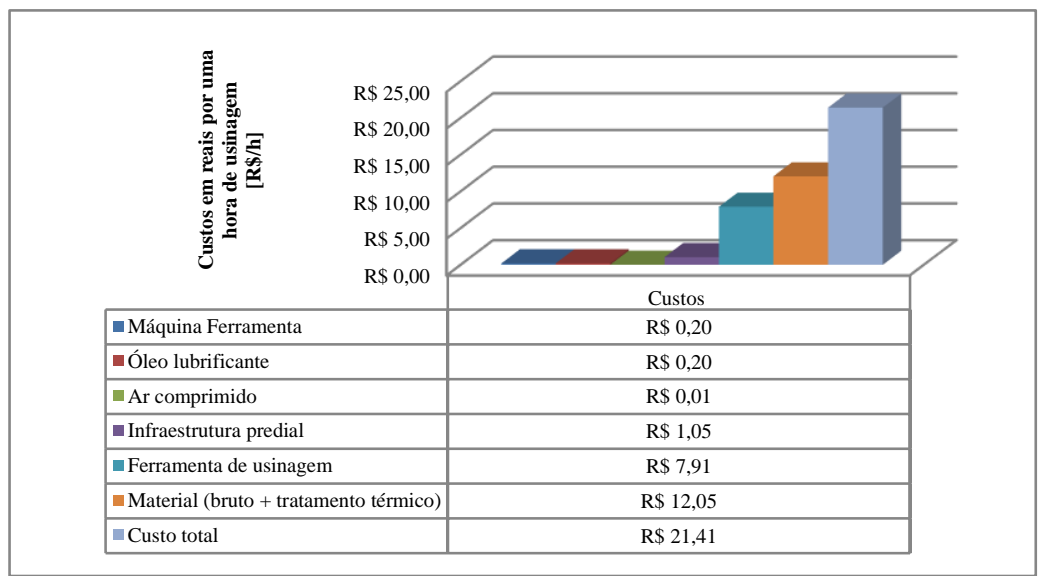

Os resultados obtidos na figura anterior foram calculados em planilha eletrônica utilizando com base a equação (3) para chegar ao custo do centro de usinagem, compressor de ar e infraestrutura predial com o tempo de utilização de uma hora. Foram considerados aqui os consumos de energia elétrica para os custos envolvidos no processo de fabricação. Os demais custos são contabilizados por meio das notas fiscais de aquisição dos materiais, ferramentas e óleo.

$\mathrm{Na}$ dimensão econômica é importante a análise dos custos envolvidos no processo de usinagem, para identificação dos custos fixos e variáveis. Com esta identificação pode-se adotar metas de melhoria para melhorar o desempenho da organização. Alguns custos são passíveis de redução com a produção de um maior número de peças (corpos de prova), o que é possibilitado por uma ferramenta de corte que não alcançou o seu fim de vida, obtendo uma boa qualidade superfície usinada.

A avaliação dos custos apresentados anteriormente está ligada diretamente ao consumo de insumos como energia elétrica, óleo lubrificante, ar comprimido e não relacionando o aporte financeiro de aquisição da máquina $\mathrm{CNC}$ e demais equipamentos, nem a liquidez econômica do investimento, uma vez que o estudo foi desenvolvido no ambiente de ensino. A possibilidade da inclusão de dados referentes à aquisição de máquinas e equipamentos é totalmente abrangida no momento de inicio da aplicação do método de avaliação se disponíveis as informações ou previsões dos mesmos. 
A infraestrutura é um custo fixo, o qual pode ter um maior ou menor impacto dependendo da produtividade. Ao decorrer do processo de fabricação dos corpos de prova no laboratório de usinagem, a configuração avaliada era em que se encontravam todas as lâmpadas fluorescentes acessas, e os dois condicionadores de ar ligados (Figura 53). Tem-se a opção de ligar os barramentos de iluminação separadamente, assim o consumo de energia seria reduzido, diminuindo o consumo energético e por sua vez o custo envolvido. Por outro lado, considerando-se simultaneamente as três dimensões do tripé da sustentabilidade (ambiental, econômica e social), a redução de luminosidade deve ser feita com o cuidado de ainda se proporcionar conforto ao operador com uma iluminação adequada do local.

Figura 53 - Laboratório de usinagem do CTISM - UFSM.

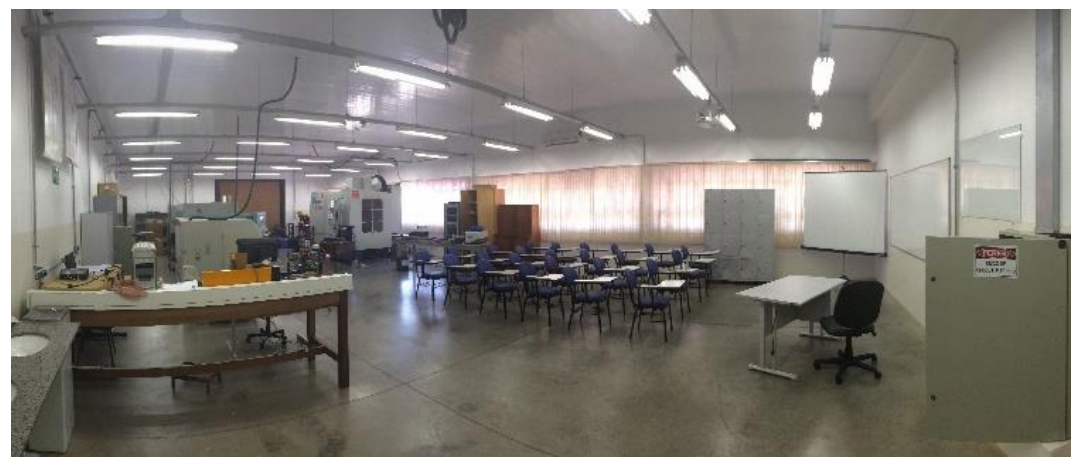

Como parte integrante do método de análise proposto no âmbito do tripé da sustentabilidade, a tabela com os resultados relacionados à etapa de classificação das observâncias do local dos experimentos é apresentada na Tabela 12. Os resultados apresentados na tabela a seguir estão relacionados para a utilização de uma hora dos insumos e no caso de materiais, como por exemplo, as ferramentas de usinagem para a usinagem de quatro corpos de prova com a trajetória trocoidal. 
Tabela 12 - Resultados da quarta etapa do método de avaliação da sustentabilidade abrangendo as dimensões ambiental, social e econômica.

\begin{tabular}{|c|c|}
\hline \multicolumn{2}{|l|}{ Máquina Ferramenta } \\
\hline Consumo de energia convertido em emissão de $\mathrm{CO}_{2}$ & $0,00011 \mathrm{tCO} 2 \mathrm{na} \mathrm{atm} / \mathrm{h}$ \\
\hline Utilização de fluido lubrirefrigerante & NÃO \\
\hline Consumo de óleo lubrificante & $0,00042 \mathrm{Litros} / \mathrm{min}$ \\
\hline Exposição do operador à contaminação química & NÃO \\
\hline Exposição a ruídos sonoros & 93,3 dB (decibéis) max \\
\hline Posição do operador durante usinagem & $\mathrm{BOA}$ \\
\hline Risco de acidente & SIM \\
\hline Consumo de energia convertido em $\mathrm{R} \$$ & $\mathrm{R} \$ 0,20 \mathrm{R} \$ /$ hora \\
\hline Consumo de óleo & $\mathrm{R} \$ 0,20 \mathrm{R} \$ /$ hora \\
\hline \multicolumn{2}{|l|}{ Matéria prima } \\
\hline Resíduo sólido & $0,0039 \mathrm{Kg} /$ peça \\
\hline Risco de acidente & SIM \\
\hline Risco de contaminação & NÃO \\
\hline Custo matéria prima & $7,28 \mathrm{R} \$ / \mathrm{kg}$ \\
\hline Custo com tratamento térmico & $8,50 \mathrm{R} \$ / \mathrm{kg}$ \\
\hline Custo com resíduos sólidos & $\mathrm{R} \$ / \mathrm{kg}$ \\
\hline \multicolumn{2}{|l|}{ Compressor de ar } \\
\hline Consumo de energia elétrica convertido em emissão de CO2 & $0,00000323 \mathrm{tCO}_{2}$ na atm \\
\hline Exposição a ruídos sonoros & $0 \mathrm{~dB}$ (decibéis) \\
\hline Custo de energia convertido em $\mathrm{R} \$$ & $0,01 \mathrm{R} \$ /$ peça \\
\hline \multicolumn{2}{|l|}{ Infraestrutura predial } \\
\hline Consumo de energia elétrica convertido em emissão de CO2 & $0,00062 \mathrm{tCO}_{2}$ na atm \\
\hline Resíduo sólido & Inferior $3 \mathrm{Kg}$ \\
\hline Climatização & SIM \\
\hline Luminosidade do ambiente & 352 lux \\
\hline Limpeza e organização & SIM \\
\hline Consumo de energia elétrica & $3,364 \mathrm{R} \$ /$ hora \\
\hline \multicolumn{2}{|l|}{ Ferramenta de usinagem } \\
\hline Resíduo sólido & $0,0085 \mathrm{Kg}$ \\
\hline Risco de acidente & NÃO \\
\hline Custo do suporte & $189,20 \mathrm{R} \$$ \\
\hline Custo com gume & 7,91 R\$/peça \\
\hline
\end{tabular}

\subsubsection{Mapa de impactos}

A gestão visual das informações usando-se padrões visuais facilita o acesso de todos a metas e objetivos da manufatura, contribuindo para eliminar desperdícios e identificar possíveis problemas [86]. Utilizado no sistema Toyota de produção tem-se o quadro "Andon", que é 
uma ferramenta de gestão visual que informa a ocorrência de anormalidades mediante aviso luminoso identificando em qual máquina ou estação de trabalho está ocorrendo um dado problema [87].

Com o intuito de elucidar as informações dos impactos inerentes ao ambiente de usinagem foi desenvolvido o mapa de impacto (Figura 55), o qual contém informações visuais do ambiente de usinagem onde são realizadas as operações de usinagem, no qual aplica-se o método de avaliação referente a questões sociais, ambientais e econômicas. O mapa de impacto contém as ocorrências observadas durante a operação de usinagem, podendo-se discutir os resultados coletados in loco e apontar melhorias no ambiente ou, ainda, possíveis causas de não conformidades do processo em uma dimensão ou mais da sustentabilidade.

O mapa de impactos apresenta informações qualitativas retratadas pelas circunferências preenchidas com uma, duas ou três cores de acordo com a legenda, simbolizando os impactos das dimensões em estudos. O mapa também contém informações quantitativas, principalmente os dados de emissão para os equipamentos e os custos produtivos dos elementos retratados no mapa.

Ainda é possível observar juntamente com as informações quantitativas símbolos relatando os riscos e análise do trabalho realizado pelo operador, nesse quesito não se tem uma normatização quanto a uma simbologia icônica direcionada a expressar tais informações segundo Facchini et al. [88]. O autor desenvolveu uma metodologia e elaborou alguns ícones que representem melhor os riscos aos quais os trabalhadores estão submetidos na linha de produção. Para demostrar os riscos presentes no ambiente de realização dos testes de usinagem da presente pesquisa serão adotados os ícones propostos por Facchini [88], conforme mostrado na Figura 54.

Figura 54 - Ícones presentes no mapa de impacto.

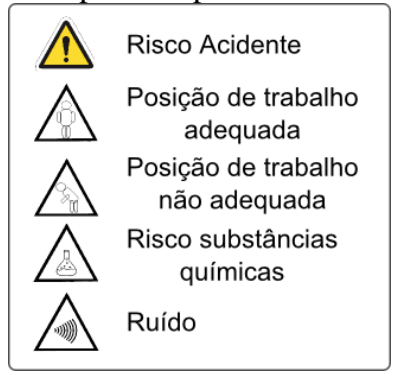


Figura 55 - Mapa de impacto referente ao fresamento do aço SAE D6 no laboratório CNC-CTISM.

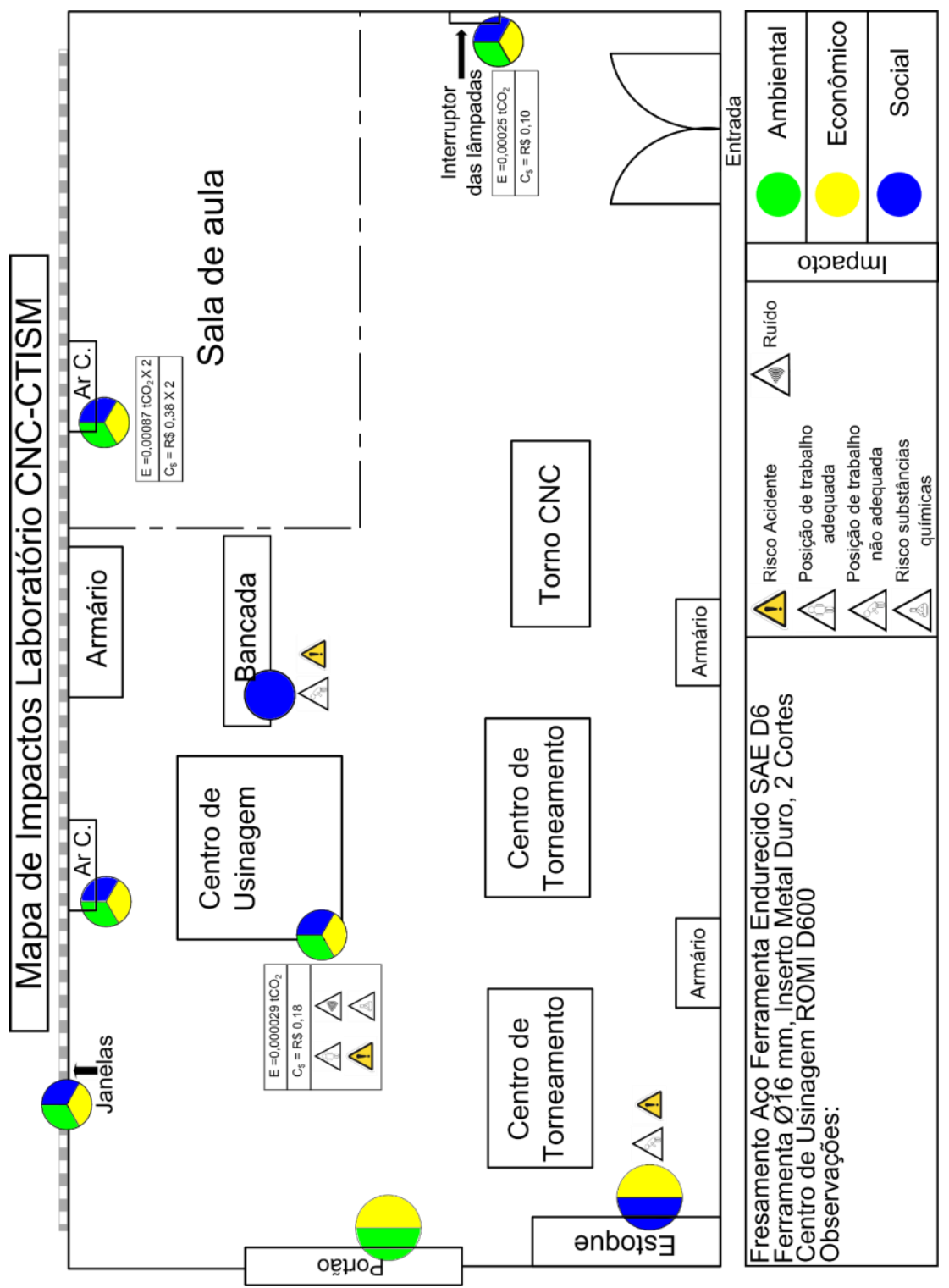




\section{CONCLUSÕES E SUGESTÕES PARA TRABALHOS FUTUROS}

Depois de aplicado o método de avaliação da sustentabilidade na usinagem por fresamento de aço ferramenta no que diz respeito ao tripé da sustentabilidade, são apresentadas neste capítulo algumas questões sobre a pesquisa desenvolvida, e são sugeridos temas a serem abordados em trabalhos futuros visando dar continuidade aos resultados obtidos neste trabalho.

Nesta pesquisa buscou-se trabalhar com material de difícil usinabilidade. Durante os testes iniciais para testar os parâmetros de usinagem comprovou-se a inviabilidade da utilização da profundidade axial de corte $a_{p}$ inicialmente definida em $0,5 \mathrm{~mm}$, uma vez que o gume entrou em colapso logo no início do primeiro contato ferramenta/peça. Assim, reduziu-se o valor de $a_{p}$ para a realização dos ensaios de usinagem deste trabalho, mantendo os demais parâmetros definidos anteriormente.

Outra questão envolvendo os parâmetros de corte relaciona-se à energia consumida na usinagem, constatando-se a dependência do consumo energético com o tempo de ciclo de trabalho para a fabricação de cada corpo de prova, visto que não foram variados todos os parâmetros de core do processo de usinagem por fresamento.

Com a variação das estratégias de usinagem e velocidades de corte, conclui-se que a trajetória trocoidal protege o gume da ferramenta mais do que as outras trajetórias. Entretanto, como esta trajetória tem um tempo de processamento muito maior que as duas outras trajetórias utilizadas, o consumo energético é maior.

Para a trajetória paralela ao perfil a velocidade de corte aplicada esteve dentro dos limites sugeridos pelo fabricante, resultando em uma rugosidade dentro dos limites considerados para o acabamento de molde e matriz, com a ferramenta de corte apresentando um desgaste inferior ao fim de vida especificado e, além disso, o consumo de energia foi inferior ao da trajetória trocoidal. Na trajetória ziguezague os gumes chegaram ao fim de vida com lascamentos e desgastes no gume principal com as duas velocidades de corte utilizadas, não aconselhando o uso dessa trajetória para a operação de acabamento.

Ao apresentar dados de qualidade da superfície usinada por meio de usinagem dura, se faz importante levar em questão o processo produtivo como um todo, não somente nas questões do produto final a ser obtido, como por exemplo, moldes de injeção plástica ou matrizes de estampagem ou conformação. 
Para o processo de fabricação de moldes e matrizes fabricados por usinagem dura, aqui é aconselhado à trajetória trocoidal, mesmo que despendida maior quantidade de energia refletindo nas dimensões econômicas e ambientais, a qualidade obtida da superfície é melhor se comparada às demais trajetórias utilizadas neste estudo, o que proporciona ganhos nas etapas posteriores de acabamento fino, principalmente no polimento em que recentemente vem sendo desenvolvidas formas de automação do processo como citado por Wilbert [8], porem corriqueiramente realizadas de forma manual e com baixa taxa de remoção necessitando um operador com elevada perícia na realização da tarefa, onde o impacto nas dimensões ambiental, econômica e social é muito maior se comparado ao processo de usinagem dura, demostrando que o desenvolvimento do estudo apresenta dados tecnológicos que contribuem para o melhoramento dos processos de usinagem em materiais endurecidos.

Outra contribuição deste trabalho quanto à usinagem dura está relacionada com o processamento do material já no estado endurecido por fresamento, diferente do que é costumeiro realizar a usinagem de materiais com durezas elevadas por meio de processo intermediário após o fresamento e anterior ao acabamento fino, em muitos dos casos é utilizado o processo de retificação para que se obtenha melhor acabamento da superfície usinada.

Com as atuais preocupações em relação ao meio ambiente e com as pessoas envolvidas no processo produtivo, não somente contabilização os custos visando o lucro da organização, tem-se tornado importante às avaliações voltas ao estudo das dimensões ambiental, econômica e social, correlacionando-as entre as mesmas para o real impacto gerado pela fabricação. $\mathrm{O}$ método aqui apresentado pelo estudo contribui na questão de conhecer o processo de usinagem, no que diz respeito à sustentabilidade, especificamente se tratando do tripé da sustentabilidade.

O método proposto fornece uma maneira de avaliar os impactos nas três dimensões do tripé da sustentabilidade, apresentando resultados qualitativos e quantitativos para a tomada de decisões visando melhorar o processo. Os resultados obtidos da avaliação não somente estão apresentados em formas de tabelas, mas também foi desenvolvida uma maneira em que auxilia a identificação de forma gráfica das ocorrências observados no ambiente de produção com o mapa de impactos auxiliando os profissionais no momento das etapas de otimização do processo.

Em comparação com outros trabalhos semelhantes que visaram qualificar e avaliar a sustentabilidade do processo, o método proposto 
neste trabalho foi idealizado para avaliação do processo, não incluindo etapas de melhoramento do processo.

Ao longo da avaliação das dimensões ambiental, econômica e social, um grande número de informações e dados é adquirido, tornado o processo trabalhoso e complexo na compilação dos dados. Além disto, há a necessidade de se conhecer diversas áreas do conhecimento técnico e tecnológico e, assim, recomenda-se o uso de uma equipe multidisciplinar nas etapas de monitoramento para que os resultados encontrados tratem os reais impactos que estão em observação, ainda facilitando na construção do mapa de impactos de forma a proporcionar uma tomada de decisões adequada quanto ao tripé da sustentabilidade.

Alguns tópicos e áreas relacionados à usinagem de aços ferramenta em estado endurecido e avaliação da sustentabilidade nas dimensões ambiental, econômica e social não foram contemplados nesta pesquisa, porém são importantes para aumentar o conhecimento científico e tecnológico na área de sustentabilidade. A seguir são listadas algumas sugestões para trabalhos futuros relacionados ao tema desta pesquisa:

- Realizar o fresamento de aços endurecidos com uma variação maior dos parâmetros de corte, tais como $a_{p}, a_{e}, f_{z}$. Pode-se também considerar diferentes formas dos corpos de prova como, por exemplo, superfícies de forma livre.

- Aplicar diferentes estratégias de fresamento de acordo com outras geometrias de corpos de prova, ou ainda aplicar outras estratégias não contempladas nesta pesquisa (por exemplo, espiral).

- Utilizar ferramentas com diferentes características como, por exemplo, o revestimento, a geometria do inserto e o diâmetro da fresa, para avaliar o impacto gerado produtividade, no acabamento superficial e no consumo de energia.

- O cálculo dos resultados, incluindo as emissões de $\mathrm{CO}_{2}$ e os custos, foi efetuado manualmente com o auxílio de planilhas. Porém, o desenvolvimento de um software voltado para avaliação do fresamento de aços endurecidos no âmbito do tripé da sustentabilidade contribuiria de maneira há reduzir o tempo para a compilação dos dados, calcular os resultados e tomada de decisão. 


\section{REFERÊNCIAS}

[1] FERREIRA, J.C.E.; WYSK, R.A. An investigation of the influence of alternative process plans on equipment control. Journal of Manufacturing Systems. Issue 6, 2001, pp. 393-406.

[2] MENEZES, L.J. Estudo das condições dimensionais e forças geradas no fresamento de aço endurecido. Campinas - SP : Dissertação (mestrado) - Universidade Estadual de Campinas, Faculdade de Engenharia Mecânica., 2014.

[3] RAO, R.V. Advanced Modeling and Optimization of Manufacturing Processes.: Springer-Verlag London Limited, 2011.

[4] GONÇALVES FILHO, E.V. Arranjo físico da fábrica: um modelo para o processo de projeto e um algoritimo para formação de células de fabricação. São Carlos : Tese - Escola de Engenharia de São Carlos, Universidade de São Paulo, 2001.

[5] CHIAVERINI, V. Tecnologia Mecânica. 2a . São Paulo : McGrawHill, 1986.

[6] WRUBLAK, O. et al. Parâmetros e métodos de usinagem e sua relação com custos do processo e o acabamento final do produto. $4^{\circ}$ Encontro de Engenharia e Tecnologia dos Campos Gerais. : s.n., 2008.

[7] SUCHY, I. Handbook of Die Design. McGRAW-HILL. Second edition. 2006.

[8] WILBERT, A.D. et al. Robot Assisted Manufacturing System for High Gloss Finishing of Steel Molds. Intelligent Robotics and Applications. 2012, 1.

[9] BÖLLINGHAUS, T. et al. Manufacturing Engineering. In: GROTE, K.H.; ANTONSSON, E.K. Springer Handbook of Mechanical Engineering. s.l. : Springer, 2008.

[10] DINIZ, A.E.; MARCONDES, F.C.; COPPINI, N.L. Tecnologia da Usinagem do Materiais. São Paulo: mm editora, 1999.

[11] SOUZA, A.J. Processo de fabricação por usinagem - Parte 1 ENG 03343. Apostila - Universidade Federal do Rio Grande do Sul. Porto Alegre, 2011. 
[12] MACHADO, A.R.; SILVA, M.B. Usinagem dos Metais. Laboratório de ensino e pesquisa em usinagem - Faculdade de Engenharia Mecânica - Universidade Federal de Uberlândia, 2004. $8^{\mathrm{a}}$ edição.

[13] TRENT, E.M.; WRIGHT, P.K. Metal Cutting. Woburn, MA : Butterworth-Heinemann, 2000. ISBN 0-7506-7069-X.

[14] LACALLE, L.N.L.; LAMIKIZ, A. Sculptured Surface Machining. In: DAVIM, J.P. Machining - Fundamentals and Recent Advances. Springer-Verlag London Limited. 2008.

[15] RANGARAJAN, A. Optimization of Face Milling Process - Tool Path and Process Planning Techniques. University of California, Berkeley. Dissertation of Doctor of Philosophy. 2005.

[16] KLOCKE, F. Manufacturing Processes 1 - Cutting.Translation: Aaron Kuchle. Berlin Heidelberg : Springer, 2011. ISBN 978-3642-11978-1.

[17] Associação Brasileira de Normas Técnicas. ABNT 6175 Usinagem - Processos mecânicos. Rio de Janeiro, 2015.

[18] GROOVER, M.P. Fundamentals of Modern Manufacturing Materials, Processes and Systems. John Wiley \& Sons, INC., 2002. ISBN 978-0470-467002.

[19] STEMMER, C.E. Ferramentas de corte II. $3^{\text {a }}$ Edição. Florianópolis. Editora da UFSC, 2005.

[20] KÖNIG, W.; KLOCKE, F. Fertigungsverfahren, Band 1: Drehen, Fräsen, Bohren. 6 Auflage. Berlin: Spring - Verlag, 2011.

[21] M'SAOUBI, R. et al. A review of surface integrity in machining and its impact on functional performace and life of machined products. Int. J. Sustainable Manufacturing. 2008, Vol. 1.

[22] GROOVER, M.P. Automação industrial e Sistemas de Manufatura. $3^{\text {a }}$ Edição. Editora Pearson, 2010.

[23] BAYER, F.M.; ECKHARDT, M.; MACHADO, R. Automação de sistemas. e-Tec Brasil, 2011.

[24] GRZESIK, W. Machining of Hard Materials. In: J.P. DAVIM. Machining - Fundamentals and Recent Advances. London. Springer - Verlag, 2008. 
[25] STOETERAU, R.L. Introdução ao Projeto de MáquinaFerramenta Modernas. Universidade Federal de Santa Catarina Dpto. Engenharia Mecânica. 2004. apostila.

[26] SOUZA, A.F. Contribuições ao fresamento de geometrias complexas aplicando a tecnologia de usinagem com altas velocidades. Tese - São Carlos: EESC-USP. Faculdade de Engenharia Mecânica, Escola de engenharia de São Carlos, 2004.

[27] BI, J.; YU, T; LI, Q. Special CNC based on advanced controller. In:WANG K. et al. Knowledge Enterprise: Intelligent Strategies in Product Design, Manufacturing, and Management. Springer US, 2006.

[28] SUH, S.H. et al. Theory and Design of CNC Systems. London. Springer - Verlag, 2008. ISBN 978-1-84800-335-4.

[29] STEMMER, C.E. Ferramentas de Corte I. $6^{\text {a }}$ Edição. Florianópolis : Editora da UFSC, 2005.

[30] DAVIS, J.R. Tool Materials - ASM Specialty Handbook. OH, USA. ASM International, 2005.

[31] ASTAKHOV, V.P. and DAVIM, J.P. Tools (Geometry and Material) and Tool Wear. In: J.P. DAVIM. Machining Fundamentals and Recent Advances. Springer - Verlag, 2008.

[32] FERRARESI, D. Fundamento da Usinagem dos Metais. Blucher, 2000 .

[33] SMITH, G.T. Cuttimg Tool Technology - Industrial Handbook. Springer - Verlag, 2008. ISBN 978-1-84800-204-3.

[34] BYRNE, G.; DORNFELD, D.; DENKENA, B. Advancing Cutting Technology. CIRP Annals - Manufacturing Technology. 2003, Vol. 52, Issue 2.

[35] GONZÁLEZ, D.M.O. Método de geração de trajetórias trocoidais e espirais combinadas para o fresamento de desbaste de cavidades 2,5D com múltiplas ferramentas. Florianópolis. Dissertação - Programa de Pós-Graduação em Engenharia Mecânica - Universidade Federal de Santa Catarina., 2013.

[36] LAMBREGTS, C.A.H. et al. An efficient automatic tool path generator 2 1/2 D free-form pockets. Computers in Industry. 1996, Vol. 29. 
[37] LACALLE, L.N.L et al. Advanced Cutting Tools. In: J.P. DAVIM. Machining of Hard Materials. Springer-Verlag, 2011.

[38] BOOGERT, R.M.; KALS, H.J.J.; VAN HOUTEN, F.J.A.M. Tool Paths and Cutting Technology in Computer-Aided Process Planning. Int. J. Advanced Manufacturing Technology. 11, 1996.

[39] LASEMI, A.; XUE, D.; GU, P. Recent development in CNC machining of freeform surface: A state-of-the-art review.

Computer-Aided Design. 2010, Vol. 42.

[40] CALLISTER, W.D. Materials Science an Engineering - An Introduction. New York,NY. John Wiley \& Sons, Inc., 1991.

[41] SILVA, F.A. Proposta de novos indicadores de qualidade para manufatura de matrizes de conformação a frio. São Paulo - SP : Dissertação - Programa de Pós-Graduação em Engenharia Mecânica - UNINOVE., 2013.

[42] BERNS, H.;THEISEN, W. Ferrous Material - Steel and Cast Iron. Berlin Heidelberg. Springer - Verlag, 2008. ISBN 978-3-54071847-5.

[43] WU, X.; XU, L. New Products and Techniques of Mould Steels. In: Y. WENG; H. DONG; Y. GAN. Advanced Steels - The Recent Scenario in Steel Science and Technology. Springer-Verlag, 2011.

[44] FLOTT, L.W. Finishing Metal Surfaces. In: H. GENG. Manufacturing Engineering Handbook. McGraw-Hill, 2004.

[45] BELLOWS, G.; TISHLER, D.N. Introduction to Surface Integrity. Cincinnati - Ohio : General Eletric - GE., 1970.

[46] PETROPOULOS, G.P.; PANDAZARAS, C.N.; DAVIM, J.P. Surface Texture Characterization and Evaluation Related to Machining. In: J.P. DAVIM. Surface Integrity in Machining. Springer-Verlag, 2010.

[47] GRZESIK, W.; KRUSZYNSKI, B.; RUSZAJ, A. Surface Integrity of Machined Surfaces. In: J.P. DAVIM. Surface Integrity in Machining. Springer-Verlag, 2010.

[48] CHOUCRI, N. Mapping Sustainability - Logic and Framework. In: CHOUCRI N. et al. Mapping Sustainability - Knowledge eNetworking and the Value Chain. Dordrecht, Netherlands. Springer, 2007. 
[49] LOPES, V.F. Método para avaliar a montagem de produtos com base no DFA no âmbito do tripé da sustentabilidade. Florianópolis. Dissertação - Programa de Pós-Graduação em Engenharia Mecânica - Universidade Federal de Santa Catarina. 2014.

[50] UN, UNITED NATION. Our Common Future, Chapter 2: Towards Sustainable Development. UN Documents - Gathering a body of global agreements. [Online]. Acessado em 4 de Janeiro de 2016. Disponível em: <http://www.un-documents.net/ocf-02.htm.>

[51] ELKINGTON, J. Towards the Sustainable Corporation: Win-WinWin Business Strategies for Sustainable Development. California Management Review. 1994, Vol. 36, 2.

[52] BARTLETT, A.A. Relfections on Sustainability, Population Growth, and the Environment. In: M. KEINER. The Future of Sustainability. Springer, 2006.

[53] HAAPALA, K.R. et al. A Review of Engineering Research in Sustainable Manufacturing. Green Manufacturing and Sustainable Manufacturing Partnership. 2013.

[54] DORNFELD, D. Sustainable Manufacturing - Greening Processes, Systems and Products. Green Manufacturing and Sustainable Manufacturing Partnership. 2010.

[55] YUAN, C.; ZHAI, Q.; DORNFELD, D. A three dimensional system approach for environmentally sustainable manufacturing. CIRP Annals - Manufacturing Technology. 61, 2012.

[56] WIMMER, W. et al. ECODESIGN - The Competitive Advantage. Springer, 2010.

[57] LU, T. et al. A Framework of Product and Process Metrics for Sustainable. Proceedings of the Eighth International Conference. 2010.

[58] GUTOWSKI, T. et al. Environmentally benign manufacturing: Observations from Japan, Europe and the United States. Journal of Cleaner Production. 13, 2005. 
[59] SANDVIK. Sustentabilidade - A reciclagem é sustentável e lucrativa. [Online] Sandvik Coromant, 2015. Acessado em: 10 de Fevereiro de 2016. Disponível

em: $<$ httpwww.sandvik.coromant.com/ptpt/services/sustainability/pages/recycling.aspx.>

[60] BHANOT, N.; RAO, P.V.; DESHMUKH, S.G. Sustainable Manufacturing: An Interaction Analysis for Machining Parameters using Graph Theory. Procedia - Social and Behavioral Sciences. 189, 2015.

[61] SANDVIK. Suplemento - Para os catálogos de Torneamento e Ferramentas Rotativas - CoroPak 14.1. SANDVIK COROMANT, 2013.

[62] MITSUBISHI. Ferramentas de torneamento - ferramentas rotativas - Soluções de fixação - C007Z. Mitsubishi Materials Corporation, 2015.

[63] KENNAMETAL. Milling Tooling. 2015. Catalog 6050 METRIC.

[64] VILLARES, METAL. Aços para trabalho a frio - VC 131. [Online] abr 2009. Acessado em: 10 de Setembro de 2015. Disponível em:

<http://www.villaresmetals.com.br/content/download/28447/28800 1/file/VC131-pt.pdf>.

[65] ARAMCHAROEM, A.; MATIVENGA, P.T. Critical factors in energy demand modelling for CNC milling and impact of toolpath strategy. Journal of Cleaner Production. 78, 2014.

[66] RAUCH, M.; DUC, E.; HASCOET, J-Y. Improving trochoidal tool paths generation and implementation using process constraints modelling. International Journal of Machine Tools \& Manufacture. 49, 2009.

[67] CAVALER, L.C.C. Fresamento periférico do aço AISI-SAE D6 temperado e revenido utilizando fresas de metal-duro. Florianópolis. Dissertação - Programa de Pós-Graduação em Enegharia Mecânica - Universidade Federal de Santa Catarina, 2003. 
[68] COLEMAN, D.E; MONTGOMERY, D.C. A Systematic Approach to Planning for a Designed Industrial Experiment. Technometrics, American Statistical Association and the American Society for Quality Control. 35, 1993.

[69] GRI, GLOBAL REPORT INITIATIVE. G4 - Diretrizes para Relato de Sustentabilidade - Parte 1. Príncipios para relato e conteúdos padrão. 2013.

[70] GRI, GLOBAL REPORT INITIATIVE. G4 - Diretrizes para Relato de Sustentabilidade - Parte 2. Manual de implementação. 2013.

[71] OECD, ORGANISATION FOR ECONOMIC CO-OPERATION AND DEVELOPMENT. Towards Sustainable Development Indicators to Mensure Progress. Paris, 2000.

[72] ARAUJO, J.B. Desenvolvimento de método de avaliação de desempenho de processo de manufatura considerando parâmetros de sustentabilidade. São Carlos. Tese - Escola de Engenharia de São Carlos - Universidade de São Paulo, 2010.

[73] Associação Brasileira de Normas Técnicas. ABNT NBR ISO 14001 - Sistemas de gestão ambiental - Requisitos com orientações para uso. Rio de Janeiro, 2015.

[74] Associação Brasileira de Normas Técnicas. ABNT NBR ISO 14031 - Gestão ambiental - Avaliação de desempenho ambiental Diretrizes. Rio de Janeiro, 2015.

[75] HACKING, T.; GUTHRIE, P. A framework for clarifying the meaning of Triple Bottom-Line, Integrated, and Sustainability Assessment. Environmental Impact Assessment. 28, 2008.

[76] KRATOCHVIL, R. Fresamento de acabamento em altas velocidades de corte para eletrodos de grafita industrial. Dissertação - Programa de Pós Graduação em Engenharia Mecânica. Universidade Federal de Santa Catarina. Florianópolis, 2004.

[77] AMORIM, H. Desgastes e avarias de ferramentas de corte. ENG03343 - Processos de Fabricação por Usinagem. Porto Alegre: DEMEC/UFRGS, 2003. 
[78] ELEKTRO. Energia Ativa e reativa. [Online] 2015. Acessado em: 4 de Janeiro de 2016. Disponível em:

<http://www.elektro.com.br/Media/Default/pdf/ELEKTRO_Energia _ativa_e_reativa.pdf $>$.

[79] CAMARINHA-MATOS, L.M. Emerging Solutions for Future Manufacturing Systems. Vienna. Springer, 2004. ISBN 978-0-38722829-7.

[80] BRASIL, Ministério da Ciência e Tecnologia. Arquivos dos Fatores de Emissão. [Online] 2015. Acessado em: 28 de JANEIRO de 2016. Disponível em:

<http://www.mct.gov.br/index.php/content/view/321144.html.>

[81] SALERNO, M.S. Análise Ergônomica do Trabalho e Projeto Organizacional: uma Discussão Comparada. Rio de Janeiro. PRODUÇÃO - ABEPRO, 2000.

[82] BRASIL, Ministério do Trabalho e Emprego. NR 17 ERGONOMIA. [Online] 2007. Acessado em: 5 de Fevereiro de 2016. Disponível em:

<http://www.mte.gov.br/images/Documentos/SST/NR/NR17.pdf.>

[83] Associação Brasileira de Normas Técnicas. NBR 5413 -

Iluminância de interiores. Rio de Janeiro : s.n., 1992.

[84] CAVALCANTI, C. Breve Introdução à Economia da

Sustentabilidade. Desenvolvimento e Natureza: Estudos para uma sociedade sustentável. Recífe, 1994.

[85] AES SUL. Tarifas e Taxas. AES Sul Clientes Corporativos. [Online] 2016. Acessado em: 20 de Janeiro de 2016. Disponível em: <https://www.aessul.com.br/grandesclientes/site/content/informacoe s/tarifas_e_taxas.aspx.>

[86] MORÓZ, G. Avaliação da aplicação da manufatura enxuta para a industria moveleira. Ponta Grossa. Dissertação - Programa de Pós-Graduação em Engenharia de Produção - UTFPR, 2009.

[87] KAMADA, S. Como Operar um “andon”. Lean Institute Brasil. [Online] 2015. Acessado em 17 de Novembro de 2015. Disponível em:

<http://www.lean.org.br/comunidade/artigos/pdf/artigo_36.pdf.> 
[88] FACCHINI, L.A. et al. Icons for occupational risk maps: a proposal developed with workers. Caderno de Saúde Pública. 13, 1997, Vol. 3. 


\section{APÊNDICE A - CERTIFICADO DE QUALIDADE DO MATERI- AL TRATADO TERMICAMENTE}

TemmeranViHe CERTIFICADO DE QUALIDADE

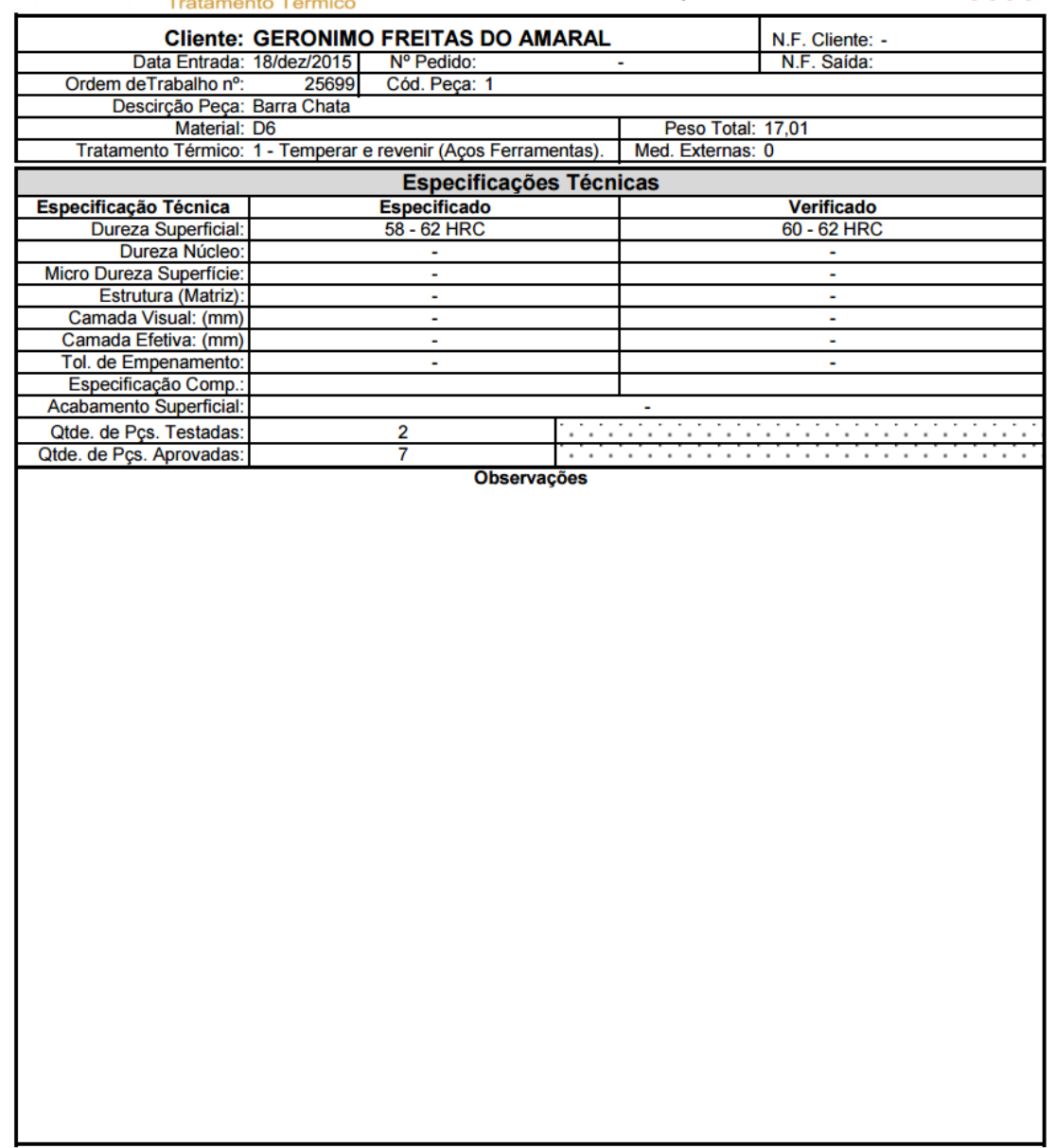

